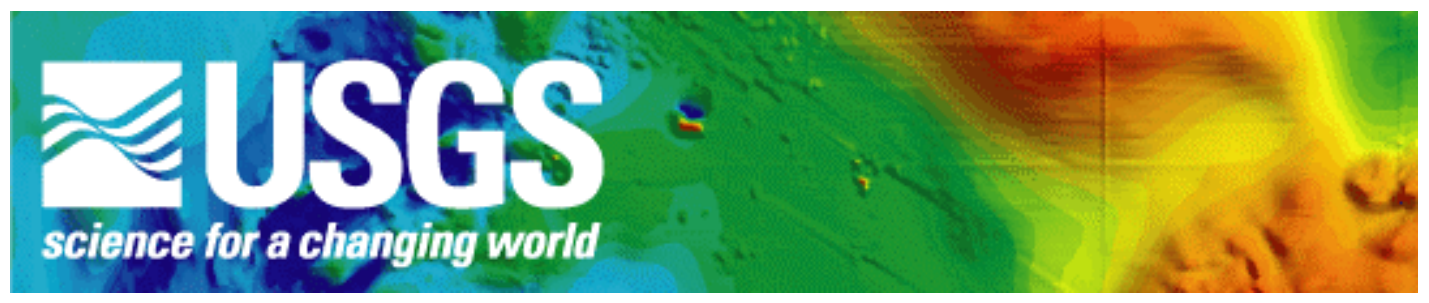

\title{
STRUCTURE OF THE TUCSON BASIN, ARIZONA FROM GRAVITY AND AEROMAGNETIC DATA
}

By Victoria Louise Rystrom

This report is preliminary and has not been reviewed for conformity with U.S. Geological Survey editorial standards or with the North American Stratigraphic Code.

Any use of trade, firm or product names is for descriptive purposes only and does not imply endorsement by the U.S. Government.

\section{Open-File Report 03-116}

U.S. Department of the Interior

U.S. Geological Survey 


\begin{abstract}
Interpretation of gravity and high-resolution aeromagnetic data reveal the three-dimensional geometry of the Tuscson Basin, Arizona and the lithology of its basement. Limited drill hole and seismic data indicate that the maximum depth to the crystalline basement is approximately 3600 meters and that the sedimentary sequences in the upper $\sim 2000 \mathrm{~m}$ of the basin were deposited during the most recent extensional episode that commenced about $13 \mathrm{Ma}$. The negative density contrasts between these upper Neogene and Quaternary sedimentary sequences and the adjacent country rock produce a Bouguer residual gravity low, whose steep gradients clearly define the lateral extent of the upper $\sim 2000 \mathrm{~m}$ of the basin. The aeromagnetic maps show large positive anomalies associated with deeply buried, late Cretaceousearly Tertiary and mid-Tertiary igneous rocks at and below the surface of the basin. These magnetic anomalies provide insight into the older $(>13 \mathrm{Ma})$ and deeper structures of the basin. Simultaneous 2.5-dimensional modeling of both gravity and magnetic anomalies constrained by geologic and seismic data delineates the thickness of the basin and the dips of the buried faults that bound the basin. This geologic-based forward modeling approach to using geophysical data is shown to result in more information about the geologic and tectonic history of the basin as well as more accurate depth to basement determinations than using generalized geophysical inversion techniques.
\end{abstract}




\section{CONTENTS}

\section{Chapter}

1. INTRODUCTION

Geologic and Tectonic History

Proterozoic

Paleozoic

Mesozoic

Cenozoic

2. PREVIOUS RESULTS 10

Geology 10

Seismic Studies 10

Gravity Studies $\quad 12$

Aeromagnetic Studies $\quad 16$

3. GEOPHYSICAL DATA 19

Gravity Data 19

Aeromagnetic Data 23

4. ANOMALY IDENTIFICATION 28

$\begin{array}{ll}\text { Gravity Map } & 28\end{array}$

Aeromagnetic Map $\quad 30$

5. MODELING OF THE GRAVITY AND

AEROMAGNETIC DATA 36

Two Dimensional Modeling $\quad 36$

Model Sensitivity $\quad 55$

Areal Extent of the Basin $\quad 57$

Three-dimensional character of the basin 58 Gravity Corrections 60

Areal Extent of the Igneous Basement $\quad 69$

6. DISCUSSION 72

$\begin{array}{ll}7 . & 75\end{array}$

REFERENCES 


\section{TABLES}

Table

Page

1. Exxon well bulk densities and susceptibilities. 32

2. Susceptibility measurements of Tucson Basin area rocks. 38

3. Susceptibilities and densities of rock units used in modeling. $\quad 50$

4. Density contrasts of basin fill and basin depths. 56 


\section{FIGURES}

Figure

1.1 Reference Map 2

1.2 Arizona Tectonic History 3

$\begin{array}{lll}1.3 & \text { Principle Strain } & 7\end{array}$

2.1 Estimated Alluvial Thicknesses 11

2.2 Davis and Litinsky Gravity Models 13

$\begin{array}{lll}2.3 & \text { Model of Saltus and Jachens } & 17\end{array}$

3.1 Locations of Gravity Stations 20

3.2 Bouguer Gravity Map 21

3.3 Maximum Horizontal Gradient of Bouguer Gravity 22

$\begin{array}{lll}3.4 & \text { Body Edge Determination } & 23\end{array}$

3.5 Reduced-to-the-Pole Aeromagnetic Map 24

$\begin{array}{lll}3.6 & \text { Pseudogravity Map } & 26\end{array}$

3.7 Pseudogravity Maximum Horizontal Gradient Map 27

4.1 Bouguer Gravity Anomaly Identification 29

4.2 Reduced-to-Pole Aeromagnetic Anomaly Identification 31

5.1 Stratigraphic Column of Exxon Well (32) 37

5.2 Exxon Seismic Line Two 43

5.3 Exxon Seismic Line Three 44

5.4 Exxon Seismic Line Four 45

5.5 Model Cross Section CS-1 46 
5.6 Exxon Seismic Line CS-2 47

5.7 Exxon Seismic Line CS-3 48

5.8 Depth to Bottom of Units 59

5.9 Regional Isostatic Gravity Field 61

5.10 Residual Isostatic Gravity Anomaly Map 62

5.11 Basement Gravity Map 63

5.12 Basin Residual Gravity Map $\quad 64$

5.13 Basin Residual Gravity Map with Depth to Lower Fill 66

5.14 Gravity and Pseudogravity Maximum Horizontal Gradients Overlying Basin Residual Gravity Map 67

5.15 Sources of Magnetization Map from Reduced-to-the Pole Aeromagnetic data 


\section{Chapter 1.}

\section{INTRODUCTION:}

The Tucson Basin, near Tucson in southeast Arizona, lies in the Southern Basin and Range Province and is surrounded by the Sierrita, Tumaccacori, Santa Rita and Rincon Mountains (Figure 1.1). A long history of volcanism, plutonism, sedimentation, erosion and tectonism has created a complex geology in the region. In order to help unravel the tectonic history of the Tucson Basin, I model existing gravity (Davis, 1971; Gettings and Houser, 1997; Sweeney and Hill, 2001) and new high-resolution aeromagnetic data (Sweeney and Hill, 2001) constrained by borehole (Davidson, 1973; Eberly and Stanley Jr., 1978; Houser and Gettings, 2000), seismic reflection (Johnson and Loy, 1992), and geologic map (Anderson, 1987; Drewes, 1976; Drewes, 1980) data, thereby integrating available geophysical data with known geology in order to understand the structure of the Tucson Basin. The results are then compared to previous geophysical inversion models of the Tucson Basin.

Geologic and Tectonic History:

\section{- Proterozoic:}

The oldest rocks in the Tucson region are the Proterozoic metasedimentarymetavolcanic Pinal Schist (Keep, 1996), part of the Mazatzal province that was accreted onto the Yavapi province of Laurentia about 1.65 Ga (Dickinson, 1989) (Figure 1.2-A). Following accretion of the Mazatzal province, a period of quiescence ensued, suggesting a possible distancing from the plate margin. In the middle Poterozoic (1.4 Ga) the Continental Granodiorite and Rincon Valley Granodiorite 


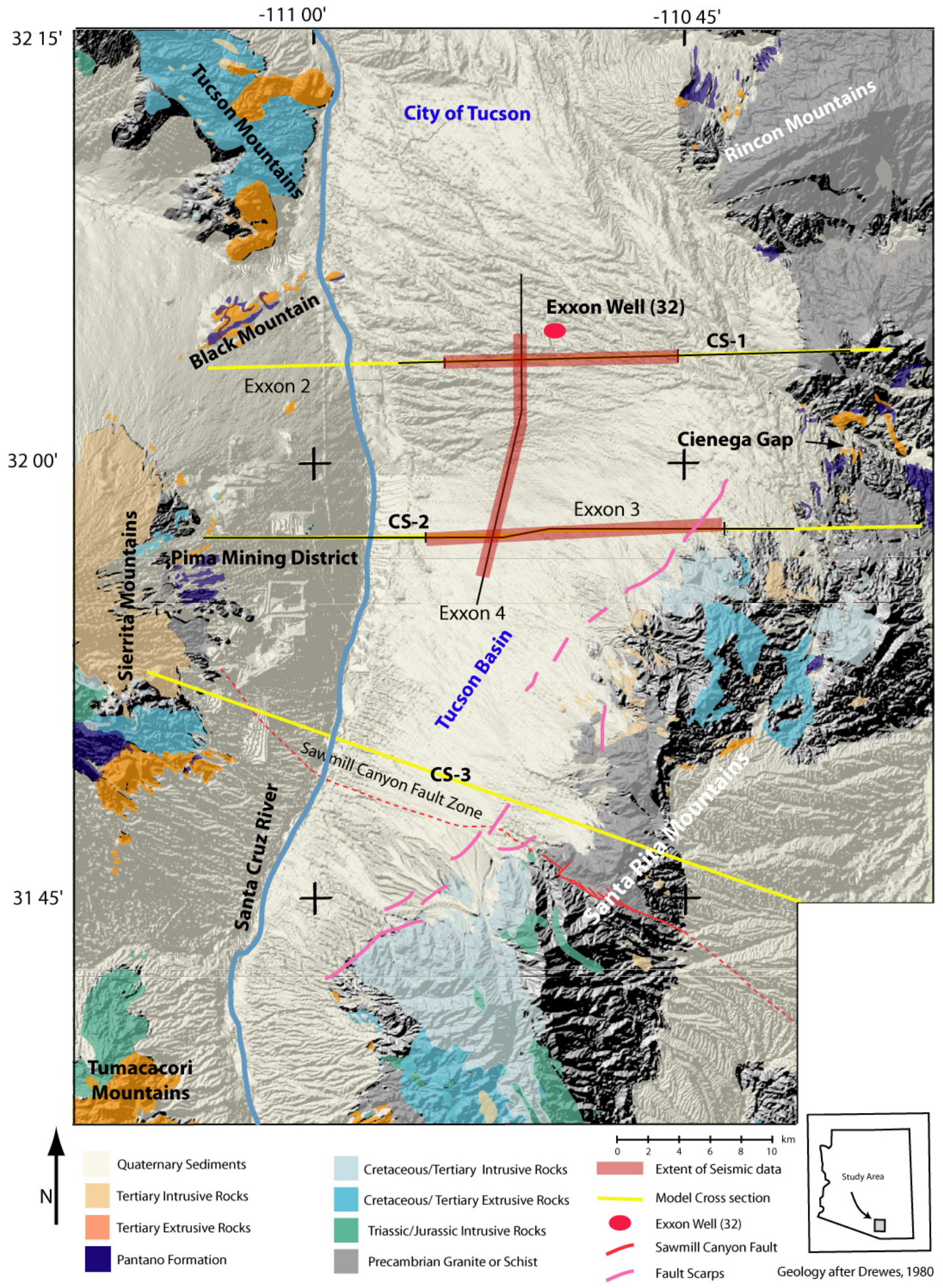

Figure 1.1: Reference Map, topography overlain by generalized geology. 


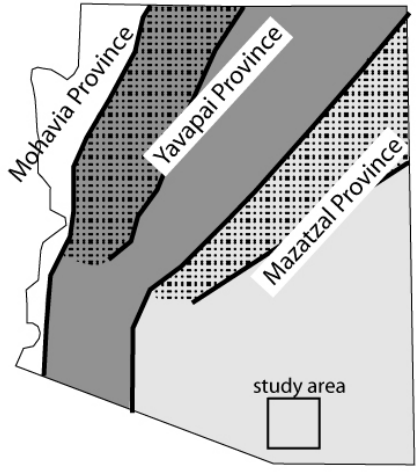

A

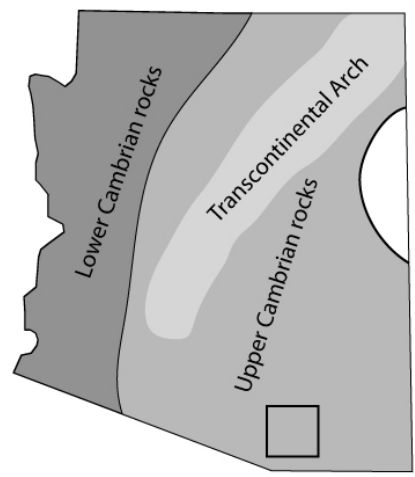

D

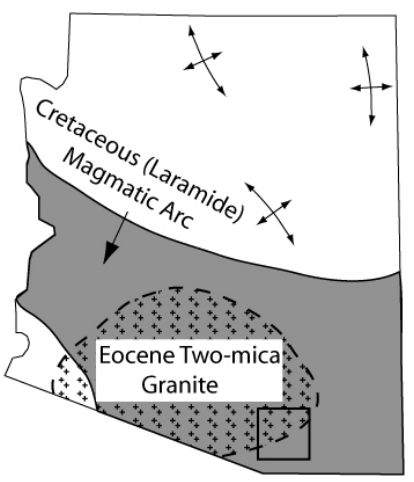

G

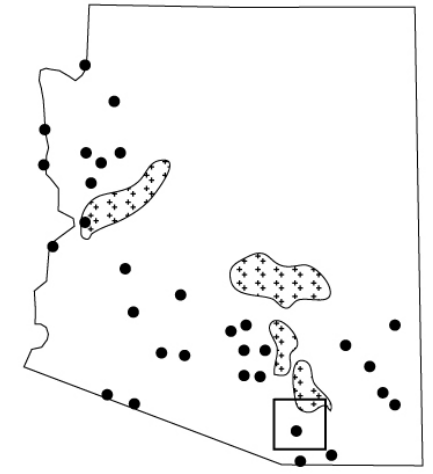

B

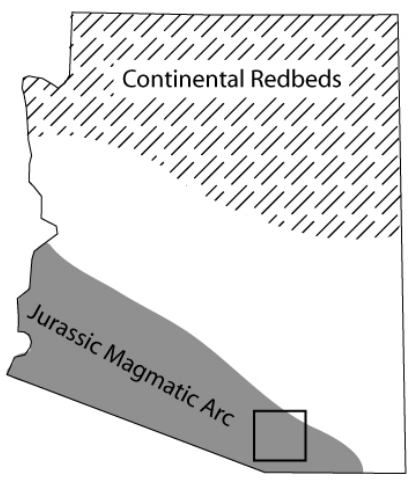

E

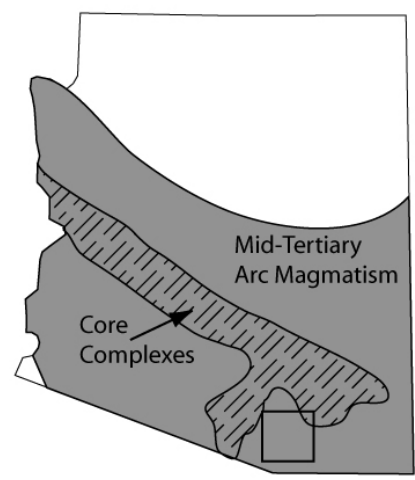

$\mathrm{H}$

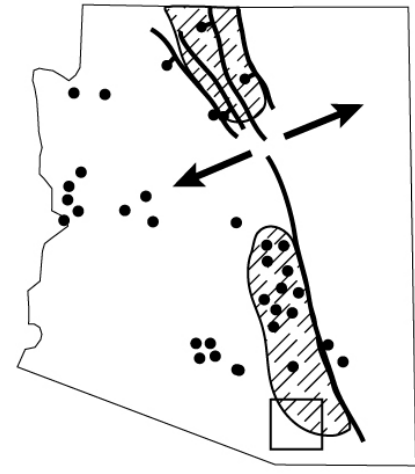

C

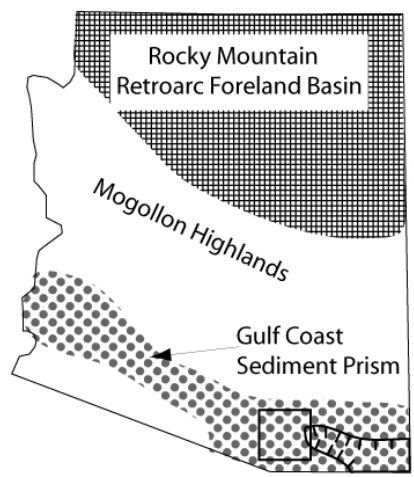

F

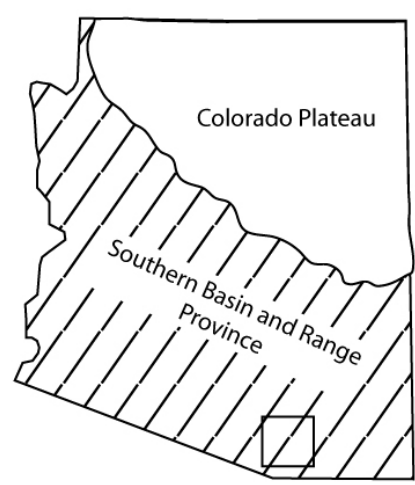

I

Figure 1.2: Tectonic History of Arizona, explanations on next page. 
Figure 1.2 explanations:

A - Proterozoic boundaries of Arizona after Karlstrom (1998) Mojave province contains Archean cust incorporated into Proterozoic crust. Yavapai province contains $1.75 \mathrm{Ga}$ volcanic-arc crust. The Mazatzal province contains $1.65 \mathrm{Ga}$ crust. The stippled areas indicate transitions between provinces.

B - 1.4Ga granitoids - stippled areas and dots. After Karlstrom and Humphreys (1998).

C - North America was simultaneously squeezed (Grenville) and rifted (midcontinent rift) possibly the cause of the Butte and Canyone Creek fault trends (bold lines) and subsequent basins (dashed lines). $1.1 \mathrm{Ga}$ mafic rocks were emplaced as diabase sheets (dots). After Karlstrom and Humphreys (1998).

D - Cambrian sediments transgressed from west to east during thermal subsidence of the Cordilleran miogeocline. Upper Cambrian and Lower Paleozoic depositional patterns were influenced by the Transcontinental arch. After Karlstrom and Humphreys (1998).

E - Early Jurassic magmatic arc plutonism related to oblique subduction off the coast of the North American plate was widespread throughout southeast Arizona. Continental Red Bed subaereal sediments were deposited in the north. After Dickinson, 1989.

F- Late Mesozoic backarc sedimentary basins formed behind the magmatic arc to the west. Subsidence during the Early Cretaceous occurred as a result of backarc crustal extension related to sea-floor spreading within the Gulf of Mexico during the Jurassic. After Dickinson, 1989.

$\mathrm{G}$ - Laramide magmatism and deformation. Gray denotes area of magmatism, stippled area, Eocene two-mica granite formation. Arrows denote basement-cored Laramide uplifts. After Dickinson, 1989.

$\mathrm{H}$ - Mid-Tertiary arc magmatism and associated extensional deformation. Dashed area denotes main belt of tectonically denuded core complexes. After Dickinson, 1989.

I - Late Cenozoic block faulting and subsidence. Lined area denotes location of Neogene extensional tectonics, Colorado Plateau is relatively undeformed. After Dickinson, 1989. 
batholiths were emplaced (Figure 1.2-B) (Davis, 1981; Drewes, 1980). A rifting event characterized by high angle faulting and diabase dike, sill and sheet intrusions occurred in the Late Proterozoic (1.1 Ga) (Davis, 1981; Dickinson, 1989; Drewes, 1981; Howard, 1991). In the period 1.1-0.6 Ga, episodic rifting oriented $\mathrm{N} 23^{\circ} \mathrm{W}$ (Figures 1.2-C, 1.3) culminated in the rifting of Laurentia from Rodinia (Karlstrom and Humphreys, 1998; Stewart, 1976). The presence of Precambrian rocks in the Tucson Basin area is limited to small widely dispersed Pinal Schist outcrops mixed with outcrops of Continental Granodiorite and Rincon Valley Granodiorite. These outcrops are limited mainly to the eastern side of the basin (Figure 1.1, gray).

- Paleozoic:

The Paleozoic era was a time of stable platform development (Figure 1.2-D), for Arizona lay within the interior of the Laurentian supercontinent (Stewart, 1976). The Paleozoic sequences in southern Arizona are composed mainly of Cambrian strata overlain disconformably by a Devonian-Permian sequence of limestone, dolomite, and interbedded mudstone to sandstone (Butler, 1971), suggesting marine conditions transitioned to sub aerial (Drewes, 1981) during the Devonian to Permian. In the Tucson Basin most Paleozoic rocks were removed in the Mesozoic, but a few outcrops remain along the Sawmill Canyon Fault, notably in the Pima Mining District (Figure 1.1) and just off the southeast corner of the study area.

- Mesozoic:

Late Triassic(?) to Jurassic magmatic arc volcanism and plutonism (Figure 1.2-E) related to oblique subduction of the oceanic Kula and (or) Farallon plates beneath the North American plate (Coney, 1979) was widespread throughout 
southeast Arizona (Dickinson, 1989). Early and Middle Jurassic plutons are thought to connect at depth to form a possible continuous batholithic belt comparable to the Sierra Nevada (Tosdal, Haxel, and Wright, 1989). Jurassic magmatism continued in southeastern Arizona from mid-Early Jurassic (c.195 Ma) to mid-Late Jurassic (c. 150 Ma) (Dickinson, 1989) then shifted westward as the Pacific subduction system moved westward. In the Tucson Basin small outcrops of these plutons are associated with the southeastern Santa Rita, northern Tumacaccori, central Sierrita and western Tucson Mountains (Figure 1.1, green).

Synorogenic high angle block faulting (Figure 1.3, shortening N71 ${ }^{\circ} \mathrm{E}$, Davis, 1981) with differential uplift caused mass-wasting and removal of all or parts of the Paleozoic section throughout Arizona (Davis, 1981; Drewes, 1981) while newly created basins filled with volcanic and sedimentary rocks (Drewes, 1981) during the Jurassic-early Cretaceous. The Sawmill Canyon Fault Zone (Figure 1.1, red fault) defines the northern extent of the known great thickness of Jurassic plutonic rocks in Arizona (Titley, 1976). This fault zone is thought to have been active at various times throughout the Mesozoic (Titley, 1982). Drewes (1971) suggests that the fault is high angle dip-slip with the northeast block up.

The Cretaceous period saw the development of thick sequences of sedimentary rocks in two different types of depositional basins (Figure 1.2-F) (Dickinson, 1989) as well as the return of arc magmatism during the Laramide orogeny. Early Cretaceous crustal extension and sediment deposition in southern Arizona (Figure 1.2-F) was possibly a product of the rifting event that opened the Gulf of Mexico (Dickinson, 1989). Thick sequences of marine and subareal 


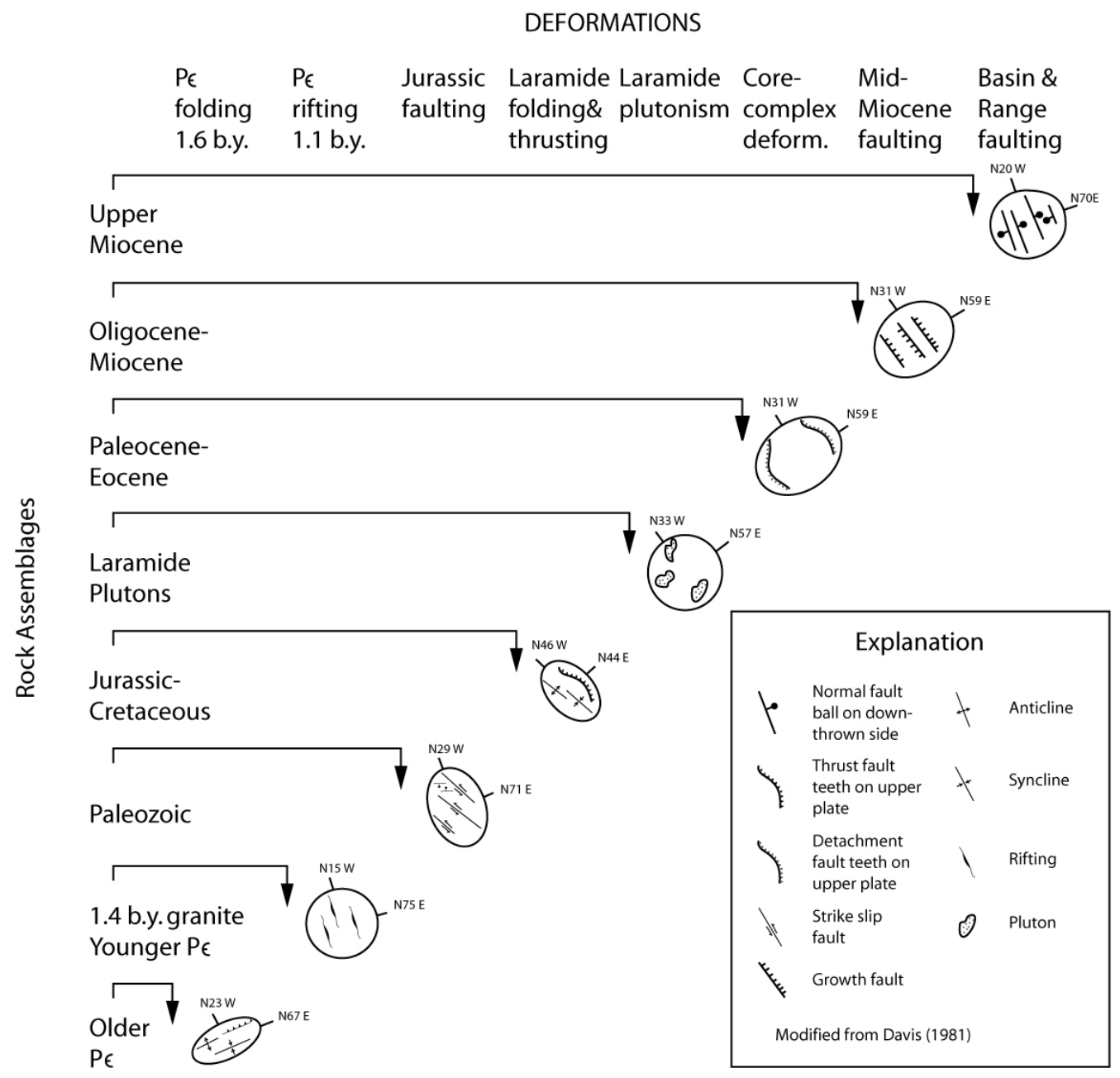

Figure 1.3: Principle strain directions for Arizona.

sedimentary rocks conformably overlie mid-Upper Jurassic volcanics and volcanoclastic rocks and are exposed in the Tucson region (e.g. Bisbee group) (Dickinson, 1989; Drewes, 1971). In the Late Cretaceous, thrusting and plate flexure from the Sevier orogeny ( $\sim 140 \mathrm{Ma})$ to the northwest of the study area created a subareal-sediment-filled foreland basin in northern Arizona. 
The Laramide orogeny ( 75-55 Ma) (Figure 1.2-G) was a period of widespread magmatism, compressional deformation, and crustal thickening (Dickinson, 1989) as a result of northeast/southwest compression (Figure 1.3, trending N46 ${ }^{\circ} \mathrm{W}$ ). Laramide magmatism included widespread volcanism (Figure 1.1, dark blue) and later granite batholith emplacement (Figure 1.1, light blue; Figure 1.2-G) (Dickinson, 1989). Large portions of the Santa Rita and Tucson Mountains and to a lesser extent the Sieritta Mountains (Figure 1.1) consist of Laramide-age igneous rocks. Reverse and thrust faulting mostly reactivated the Jurassic (and probably Precambrian) faults (Davis, 1981). Narrow bands of folded Cretaceous sedimentary rocks with axes striking northwest and west-northwest developed. The Sawmill Canyon Fault Zone parallels one such band. Crustal thickening across the southern half of Arizona induced regional uplift (Dickinson, 1989) and subsequent erosion.

\section{- Cenozoic:}

Closely following the Laramide orogeny, the crust was intruded by scattered batholiths of two-mica granite during Early to Middle Eocene time ( $\sim 55-45 \mathrm{Ma})$ (Dickinson, 1989), the batholiths were produced by crustal melting. No volcanic equivalents are known. The Late Eocene was a time of tectonic quiescence with low topographic relief, followed by the Mid-Tertiary orogeny (Oligocene to middle Miocene), when arc magmatism and widespread extensional deformation returned to the region (Figure 1.2-H) (Dickinson, 1989) due to the evolving plate tectonic setting of the western continental margin. Important tectonic events include widespread rhyolitic to basaltic volcanism (Figure 1.1, dark orange), shallow crustal plutonism (Figure 1.1, light orange), development of depositional basins and extension (Menges 
and Pearthree, 1989). The youngest volcanic rocks in the Tucson Basin region are 33-23 Ma andesitic, dacitic, and rhyolitic flows, tuffs, pyroclastic rocks, dikes, plugs and laccoliths (Spencer and Reynolds, 1989). Andesitic flows are found in the Tumacaccori Mountains (Figure 1.1, dark orange). Mid-Tertiary crustal extension was associated with east-northeast-west-southwest-directed low-angle normal faulting (Zoback and Zoback, 1991), and block rotation that accommodated large amounts of extension (Spencer and Reynolds, 1989). Detachment faults in Arizona, some associated with metamorphic core complexes, have a few to several tens of kilometers of displacement and some think (Spencer and Reynolds, 1989) that they are one of the most important structural features of mid-Tertiary age. An important sedimentary sequence in the region, the Pantano Formation (Figure 1.1, purple), was deposited as a result of uplift of the core complexes.

High-angle normal faulting associated with Basin and Range extension began in southeast Arizona around $13 \mathrm{Ma}$ and continued until 5Ma, resulting in northwest to northeast trending ranges and alluvial valleys (Menges and Pearthree, 1989) (Figure 1.2-I). Compared with the Great Basin portion of the Basin and Range province, there is more variety in the trends of the ranges in Arizona (Loring, 1976). Late Tertiary and Early Quaternary basaltic flows are associated with Basin and Range extension; however, the Tucson Basin area is devoid of these rocks. 


\section{Chapter 2}

\section{PREVIOUS RESEARCH:}

\section{Geology:}

The primary interest of geologic studies of the mountains surrounding the Tucson Basin has been mineral deposits; geologic studies in the basin itself have focused on water resource and quality issues. The USGS undertook a geologic study of the central, northern and eastern portion of the basin in 1959 (Pashley, 1966) to do a water recharge study, and from 1970 to 1973 produced detailed studies of the hydrology of the Tucson Basin (Anderson, 1972; Burkham, 1970; Davidson, 1973; de la Torre, 1970; Laney, 1972). Again in 1987, the USGS cooperated with the City of Tucson to combine the data from more than 500 wells to define the characteristics of the basin sediments (Anderson, 1987). An alluvial deposits thickness map of the Tucson area was produced by the USGS in 1973 (Cooley, 1973), however the contours are limited to a maximum depth of 365 meters (Figure 2.1). In 1972, Exxon drilled $3600 \mathrm{~m}$ to crystalline basement in the north end of the basin. Eberly and Stanley (1978) interpreted the well logs. These were reinterpreted along with the stratigraphy of the basin sediments by Houser and Gettings (2000). These well logs have been important in studying the Tucson Basin, for they are the only logs to reach crystalline basement (Houser and Gettings, 2000). Other examinations of localized geology have been covered in many University of Arizona thesis and dissertations. Seismic Studies:

An east-west cross section of the northern portion of the Tucson Basin correlating the Exxon State (32) well log data and reflection seismic lines was created 


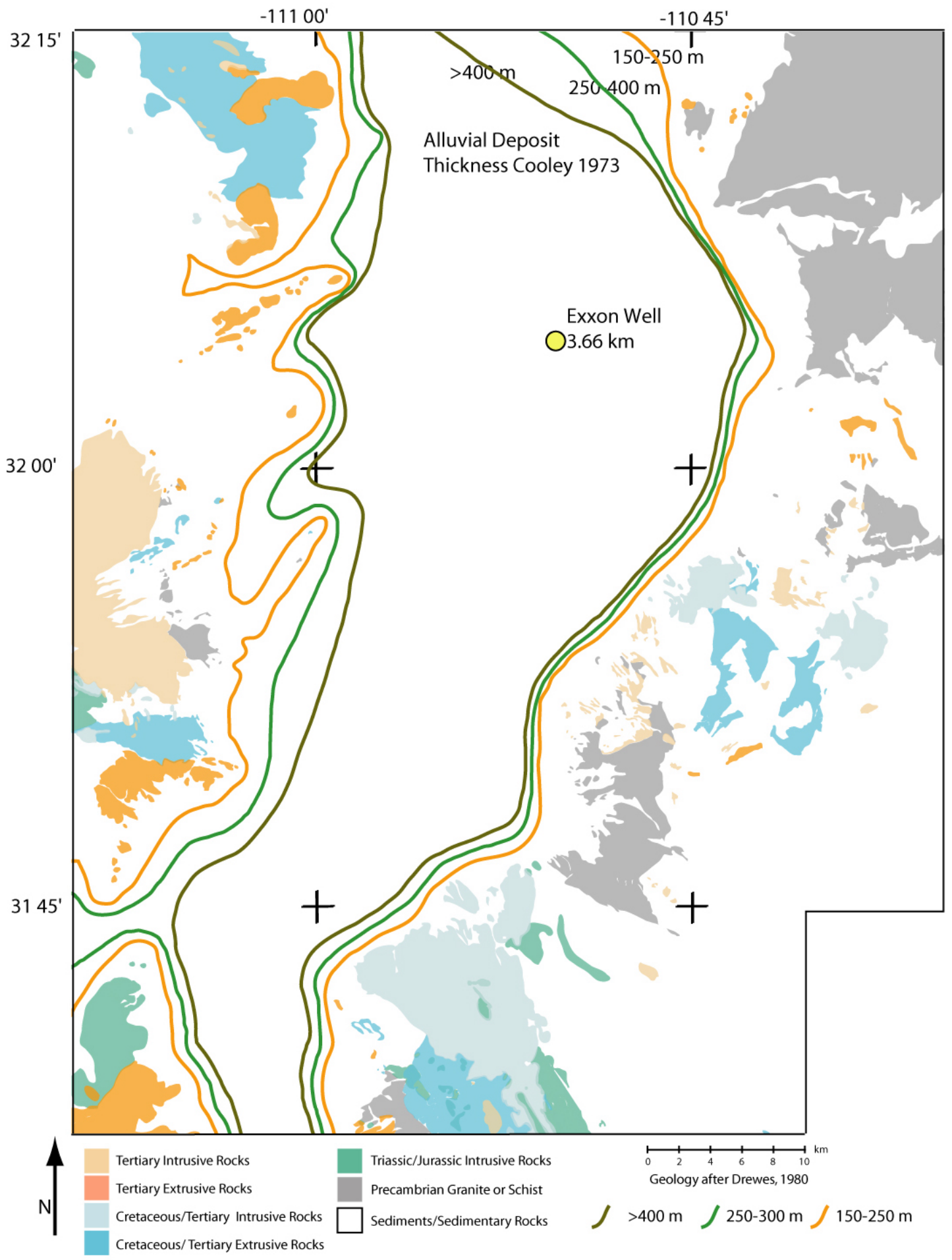

Figure 2.1 Alluvial thickness contours based on wells from Cooley 1973. Generalized geology from figure 1.1.Depth to bedrock of Exxon well (32) shown for reference. 
by Eberly and Stanley (1978). They suggest a late Miocene symmetric high angle faulted basin with a central graben surrounded by sets of homothetic faults. They further suggest that the basin was once a narrow valley between broad ranges that has subsequently eroded and widened (Eberly and Stanley Jr., 1978).

Interpretation of a seismic reflection line across the Tucson Basin (Johnson and Loy, 1992) show a low-angle normal fault (the Santa Rita Fault) that crops out along the trend of late Quaternary fault scarps (pink, Figure 1.1). Velocityindependent dip analysis from shot records of the Santa Rita fault indicate that it has a true northwestdip of $\sim 20^{\circ}$ to a depth of at least $6 \mathrm{~km}$.

Limited seismic refraction and receiver function data have been collected in the region. Receiver function data (Myers and Beck, 1994) indicate that the crustal thickness increases from $30 \mathrm{~km}$ under the Tucson basin to $34 \mathrm{~km}$ under the Rincon Mountains. Refraction data, primarily along the Santa Rita Fault (indicated by fault scarps, Figure 1.1), show Quaternary normal faults offsetting piedmont surfaces of the Pliocene to late Pleistocene (Pearthree and Calvo, 1987; Rutledge, 1984).

\section{Gravity Studies:}

Several previous studies have modeled gravity data in the Tucson Basin region. Davis (1971) modeled gravity data collected in the Tucson area for the purposes of identifying major hydraulic boundaries of the Tucson Basin (Figure 2.2, a, b). The study used a 2-dimensional modeling program to model the depth to basement using an average crustal density of $2670 \mathrm{~kg} / \mathrm{m}^{3}$. A density contrast of -400 $\mathrm{kg} / \mathrm{m}^{3}$ represented the density contrast between the basin fill and the Pantano Formation and the pre-Tertiary crystalline basement rocks (Davis, 1971). The basin 


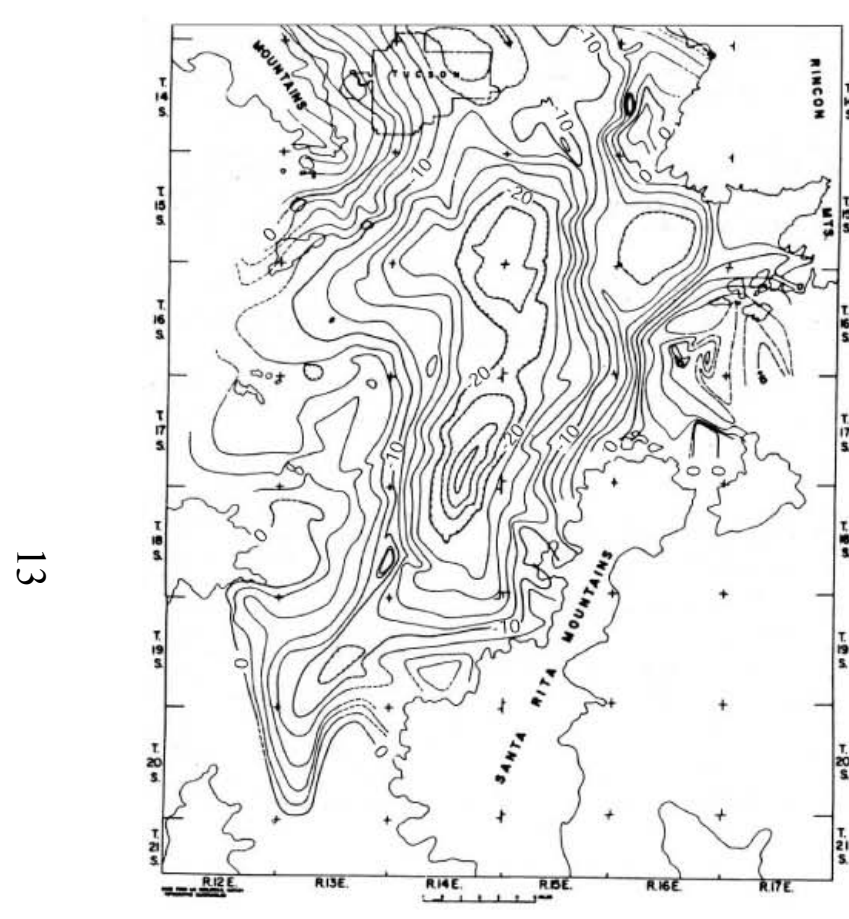

a

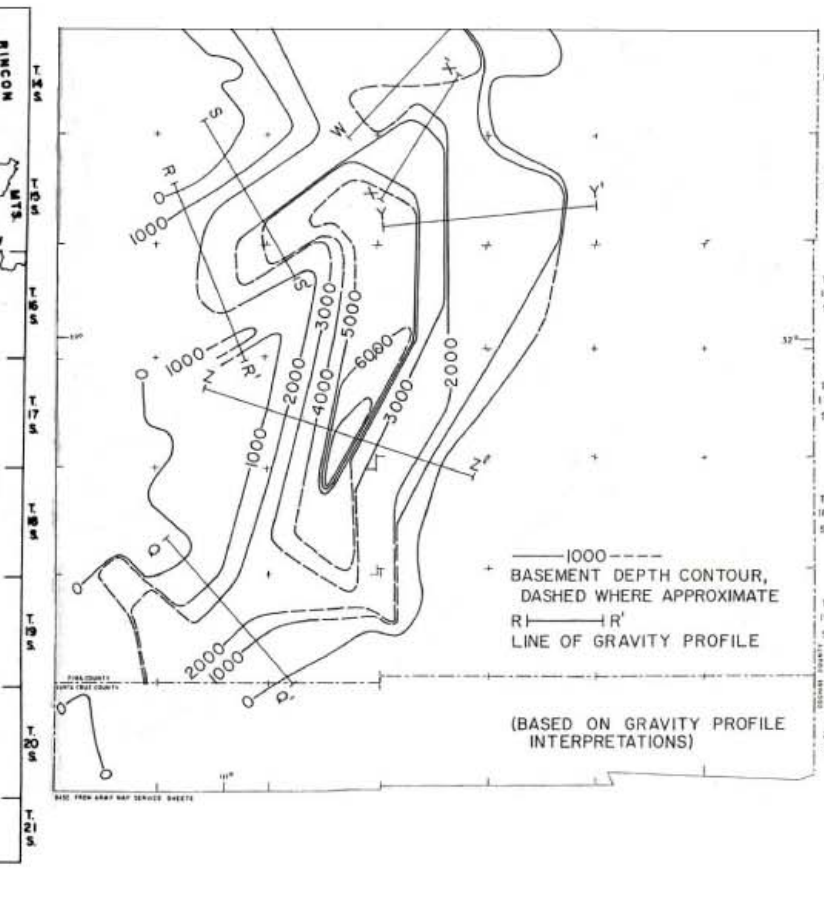

$\mathrm{b}$

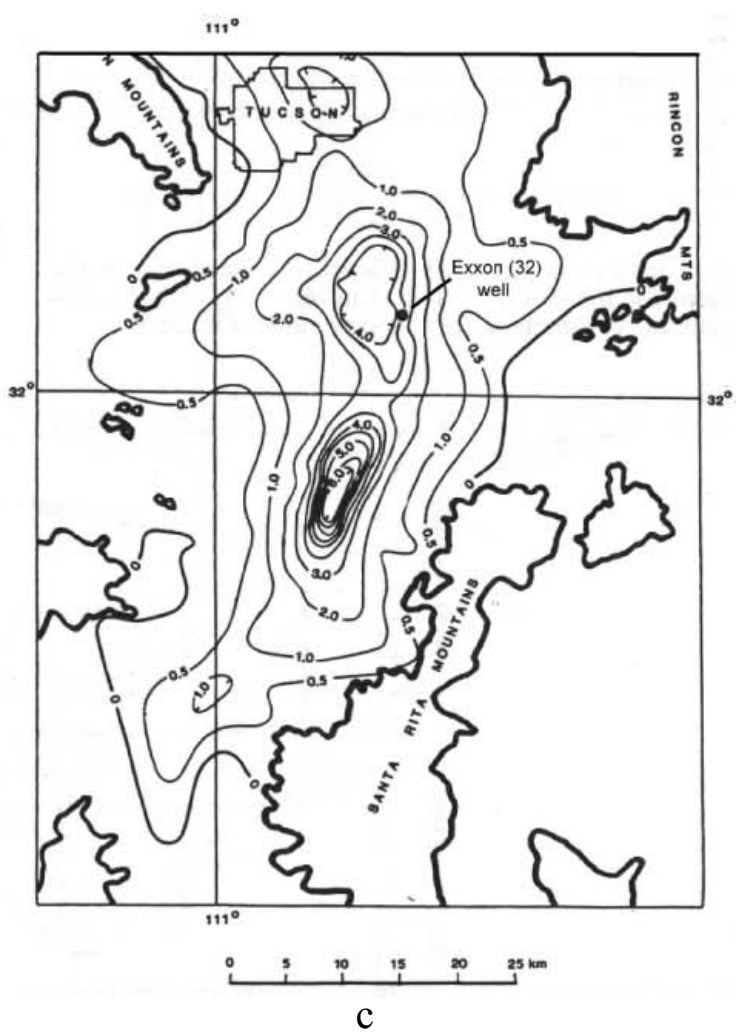

Figure 2.2: a. Residual Bouguer gravity from Davis (1971), 2 mGal contours, b. Basement depth contours in feet from Davis (1971), c. Basement depth contours in km of Litinsky, after Litinsky (1989). Maps are all approximately same scale. 
fill consists of late Pliocene to Holocene sedimentary sequences (Figure 1.1). The bottom of the basin is assumed to be the bottom of the Pantano Formation (Figure 1.1). Davis removed a regional gradient from the Bouguer gravity data. The regional gradient removal was based on representative values for Bouguer gravity in broad areas of granitic or metamorphic terrain. These values were then corrected for topographic effects. The resulting regional gradient was defined as a plane dipping $\mathrm{S} 20^{\circ} \mathrm{E}$ at $1 \mathrm{mGal} / \mathrm{mile}(0.62 \mathrm{mGal} / \mathrm{km})$ (Davis, 1967). The resulting residual Bouguer gravity anomalies were used to model the 3-dimensional geometry of the Tucson Basin. The model shows the deepest portion of the basin to be south of and shallower than Exxon well (32) at $2.15 \mathrm{~km}$ (7000 feet, Figure 2.2, b).

Another study of the entire Arizona Basin and Range province including the Tucson Basin also used residual gravity data to obtain basin thickness. (Oppenheimer, 1980; Oppenheimer and Sumner, 1981) A regional was calculated using a double Fourier trend surface analysis of elevations. The trend surface elevations were calculated by averaging the elevations within $1 \mathrm{x} 1$ ' squares on a topographic sheet. Oppenheimer related this removal to crustal thickening from the southwest to the northeast. To determine depth to bedrock from the residual gravity data a variable density scale was used and, for the Tucson region, the depth to crystalline basement determined from the Exxon well (32) was used as a constraint. Their 3-dimensional model shows a mostly north-south trending narrow basin whose thickest section is about $3800 \mathrm{~m}$ near the location of the Exxon well. 
Two later studies also used the Exxon well to constrain their models, with the assumption that the base of the sedimentary basin coincided with the top of the crystalline basement (3.66 km depth). Litinsky (1989) calculated the depths to basement using a hyperbolic density depth function with an effective density contrast of $-137 \mathrm{~kg} / \mathrm{m}^{3}$ and the Bouguer infinite-slab formula from residual gravity data (Davis, 1971) over the Exxon well (32) borehole A maximum depth of $10 \mathrm{~km}$ was obtained for the southern portion of the basin (Figure 2.2, c). The shape of the basin is similar to that of Davis (1971). Chakrarathi, et al. (2001) (also using the residual Bouguer gravity of Davis (1971)) inverted a gravity anomaly profile across the Tucson Basin using a parabolic density function with a surface density contrast of $450 \mathrm{~kg} / \mathrm{m}^{3}$ and a depth-density relation of $280.6 \mathrm{~g} / \mathrm{m}^{3} / \mathrm{km}$. Assuming the depth of $3.6 \mathrm{~km}$ from the Exxon well (32) a density distribution was determined. This approach yielded a thickness of $3.8 \mathrm{~km}$ in the northern part of the Tucson Basin (near the Exxon drill hole).

Another approach was used by Saltus and Jachens (1995) who removed regional gravity anomalies from the Bouguer gravity field for the western United States in order to isolate anomalies related to Cenozoic basins. They first removed the isostatic effect of the terrain (Simpson et al., 1986). They recognized that the basement exposed in ranges adjacent to the basins varied in density. In order to correct for this effect they gridded the isostatic residual gravity data using only the data over the basement outcrops to create a basement gravity field. This was subtracted from the isostatic residual anomaly to obtain the gravity anomaly associated with the basins, referred to here as the residual basin gravity anomaly. 
This regional-removal process will be discussed in detail in a later section. The thicknesses of the basins (figure 2.3) were then modeled using a density-depth function in which a stepped density contrast decreases with depth $(0-0.2 \mathrm{~km},-650$ $\mathrm{kg} / \mathrm{m}^{3} ; 0.2-0.6 \mathrm{~km},-550 \mathrm{~kg} / \mathrm{m}^{3} ; 0.6-1.2 \mathrm{~km},-350 \mathrm{~kg} / \mathrm{m}^{3}$ and $\left.>1.2 \mathrm{~km},-250 \mathrm{~kg} / \mathrm{m}^{3}\right)$. The deepest part of the Tucson Basin in their model was at greater than $2.5 \mathrm{~km}$ near the location of the Exxon drill hole (Figure 2.3), shallowing to $500 \mathrm{~m}$ at the southern portion of the basin. In all of these models, no attempt was made to link density layers with stratigraphy, especially important in area with a complex tectonic history like the Tucson Basin.

Aeromagnetic Studies:

The first aeromagnetic survey in the region, in 1959, (Andreasen and Pitkin, 1963) was over the Twin Buttes area in the Sierrita Mountains. A statewide survey was flown in 1968 (Summer and Sauck, 1971), at 2740m constant elevation and 5km line spacing. Only three flight lines covered this study area. A higher resolution survey $(1830 \mathrm{~m}$ constant elevation and $800 \mathrm{~m}$ and $1600 \mathrm{~m}$ line spacing) was flown later in 1968 for a northern portion of the Tucson Basin (Sauck, Sumner, and Christensen, 1971).

The 1968 survey profiles contained several major positive magnetic anomalies over the Tucson Basin area. The dominant feature is a positive anomaly with amplitudes up to $300 \mathrm{nT}$ and trending N45 ${ }^{\circ} \mathrm{W}$ (Sauck, Sumner, and Christensen, 1971), in the northeast corner of the Tucson Basin over the Rincon Mountains (A5, Figure 4.2) that they suggested is caused by a batholith with an age of either Late Cretaceous (not Laramide), Laramide, or mid-Tertiary. Depth to source estimates 


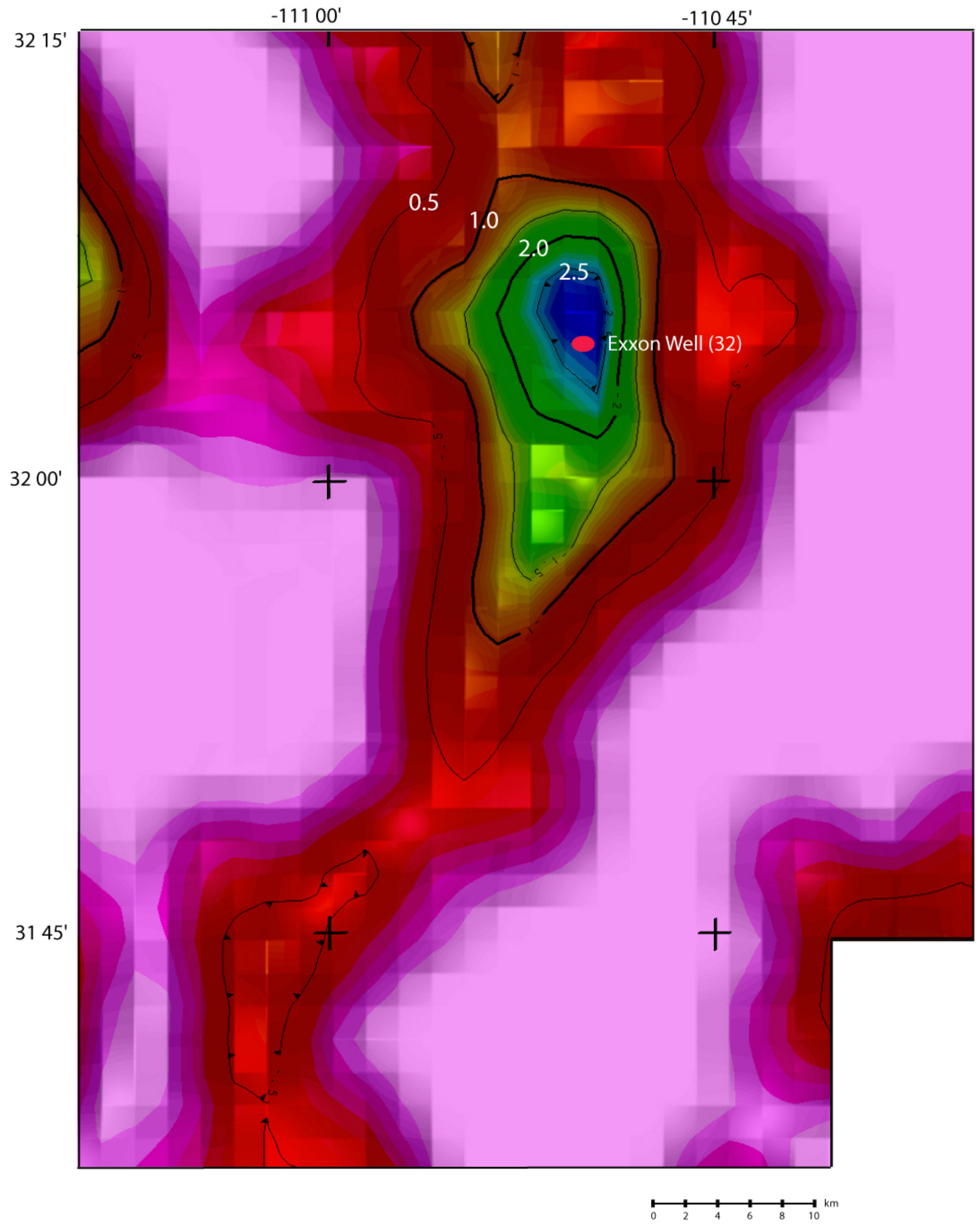

Figure 2.3: Depth to basement map derived from basement-corrected gravity anomalies (Saltus \& Jachens, 1995). See text for explanation. Contours show depth in kilometers. Exxon well (32) shown for reference. 
ranged from $330 \mathrm{~m}$ to $1130 \mathrm{~m}$ and they suggested most of the source is considerably deeper. They also postulate a minimum susceptibility of 0.02 (SI) for the source and note that the gneiss (A5, Figure 4.2) overlying has susceptibility measured at 0.00082 (SI) and is an unlikely source for the high positive anomaly. Other positive anomalies identified over the area are smaller and were thought to be dikes unrelated to the larger batholithic anomaly source (Sauck, Sumner, and Christensen, 1971). 


\section{Chapter 3}

\section{GEOPHYSICAL DATA:}

Gravity Data

This study uses 2349 gravity stations from a database maintained by the National Geophysical Data Center, augmented with data from the USGS and several university theses and dissertations (Sweeney and Hill, 2001) (Figure 3.1). Free-air, and Bouguer corrections, calculated using the 1967 gravity formula (International Association of Geodesy, 1971) and a reduction density of $2670 \mathrm{~kg} / \mathrm{m}^{3}$ were applied to the data. Terrain corrections were calculated radially outward $167 \mathrm{~km}$ from each station using a method developed by Plouff (1977). The irregularly-spaced data were converted to a regular grid with a $500 \mathrm{~m}$ spacing using minimum curvature (Sweeney and Hill, 2001) (Figure 3.2).

Derivatives of gravity data can highlight features of interest. One of the goals of this study is to locate the edges of the Tucson basin. To aid in this, I used the magnitude of the maximum horizontal gradient of the Bouguer gravity to highlight the edges of rock units or faults (Blakely, 1995). The maximum horizontal gradient method can be applied to both magnetic and gravity data (Figure 3.3), and uses the amplitude of the horizontal component of the gravity or magnetic gradient (Cordell and Grauch, 1985). The position of the gravity inflection point is easily determined by locating the peak in the amplitude of the horizontal gradient of the gravity field (Figure 3.4). The interpretation of this map will be discussed in a later section. 


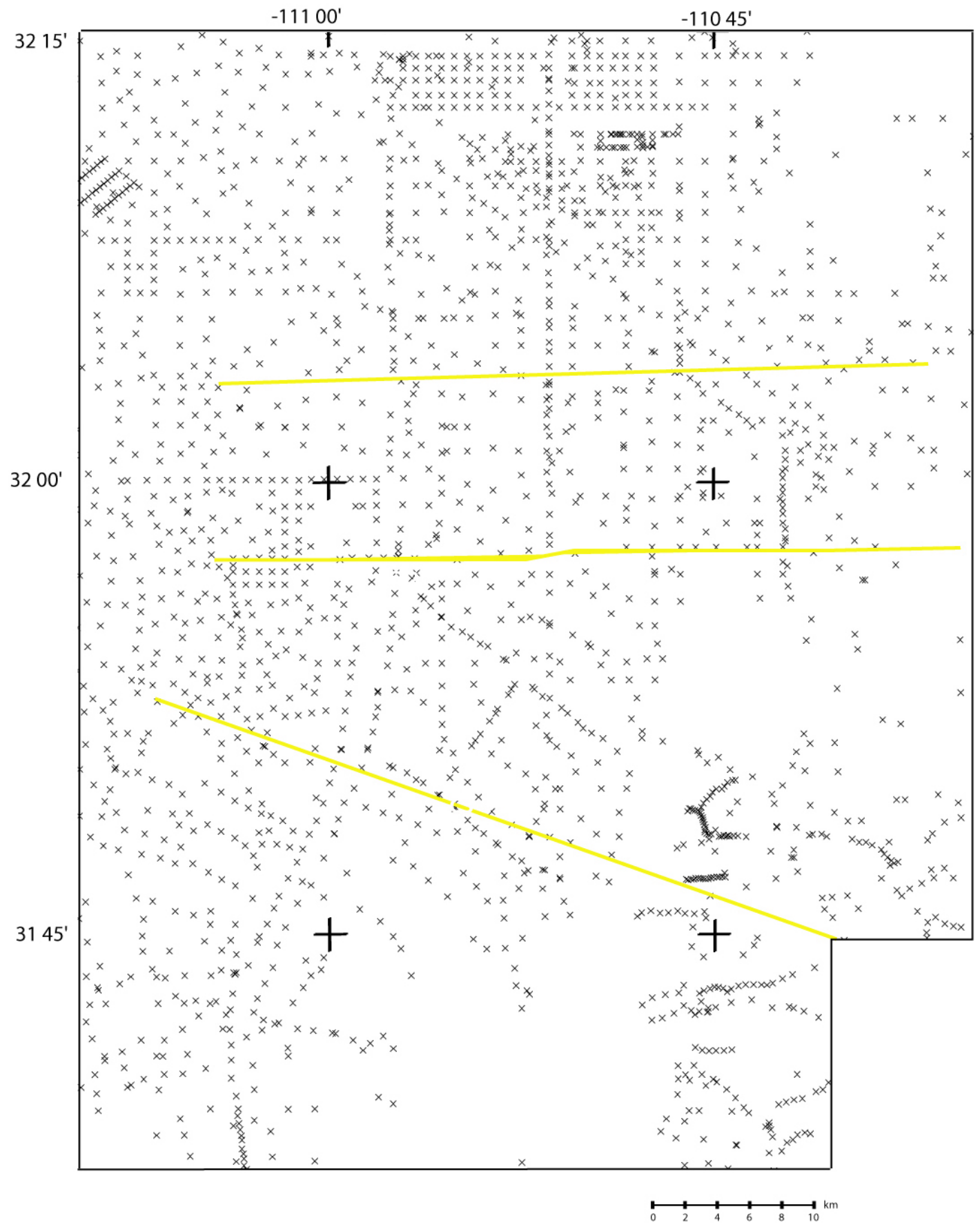

Figure 3.1: Locations of gravity stations used in calculating Bouguer gravity anomalies. Yellow lines show locations of model cross sections. 
$-11100^{\prime}$

$-11045^{\prime}$

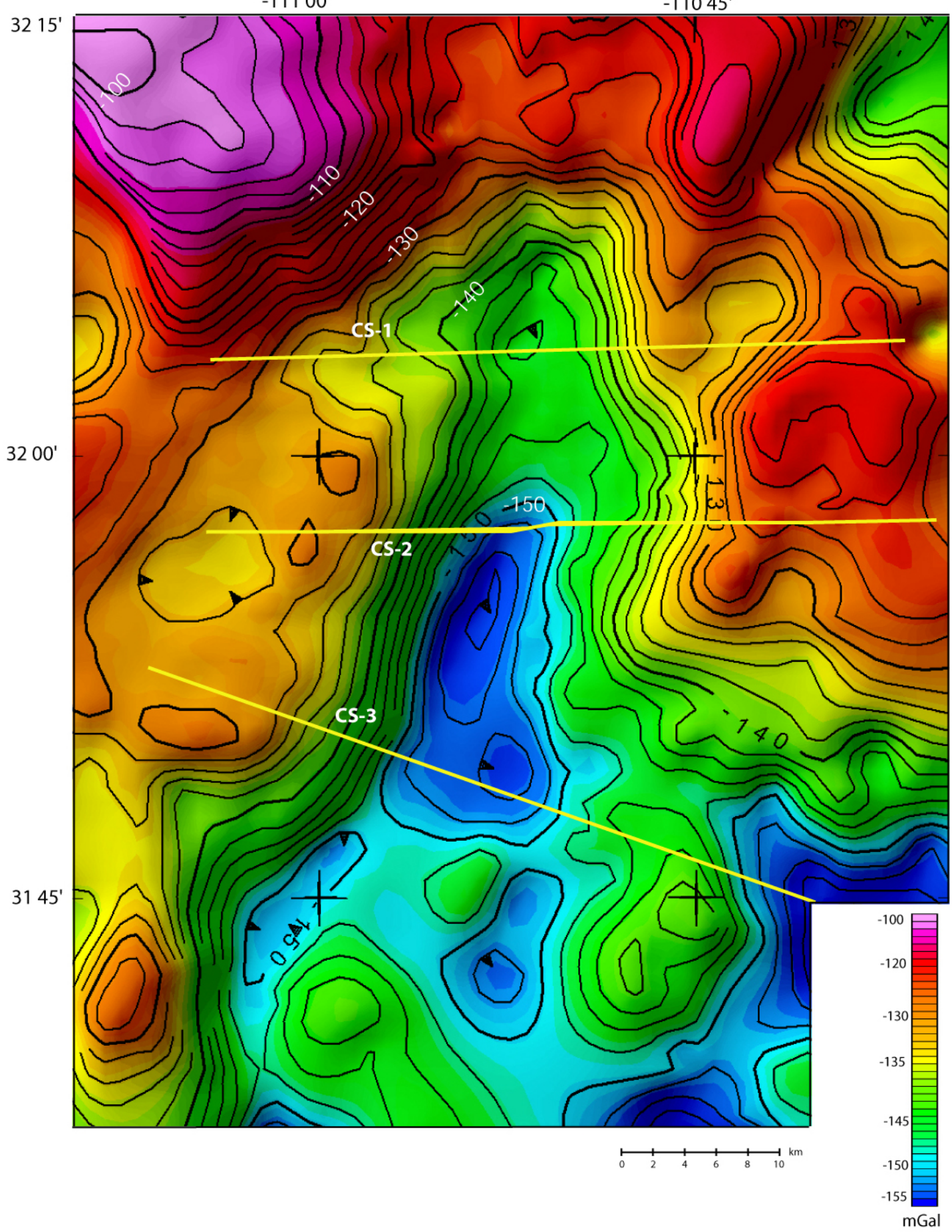

Figure 3.2: Bouguer gravity anomaly map, $2 \mathrm{mGal}$ contours. Yellow lines show locations of model cross sections. 


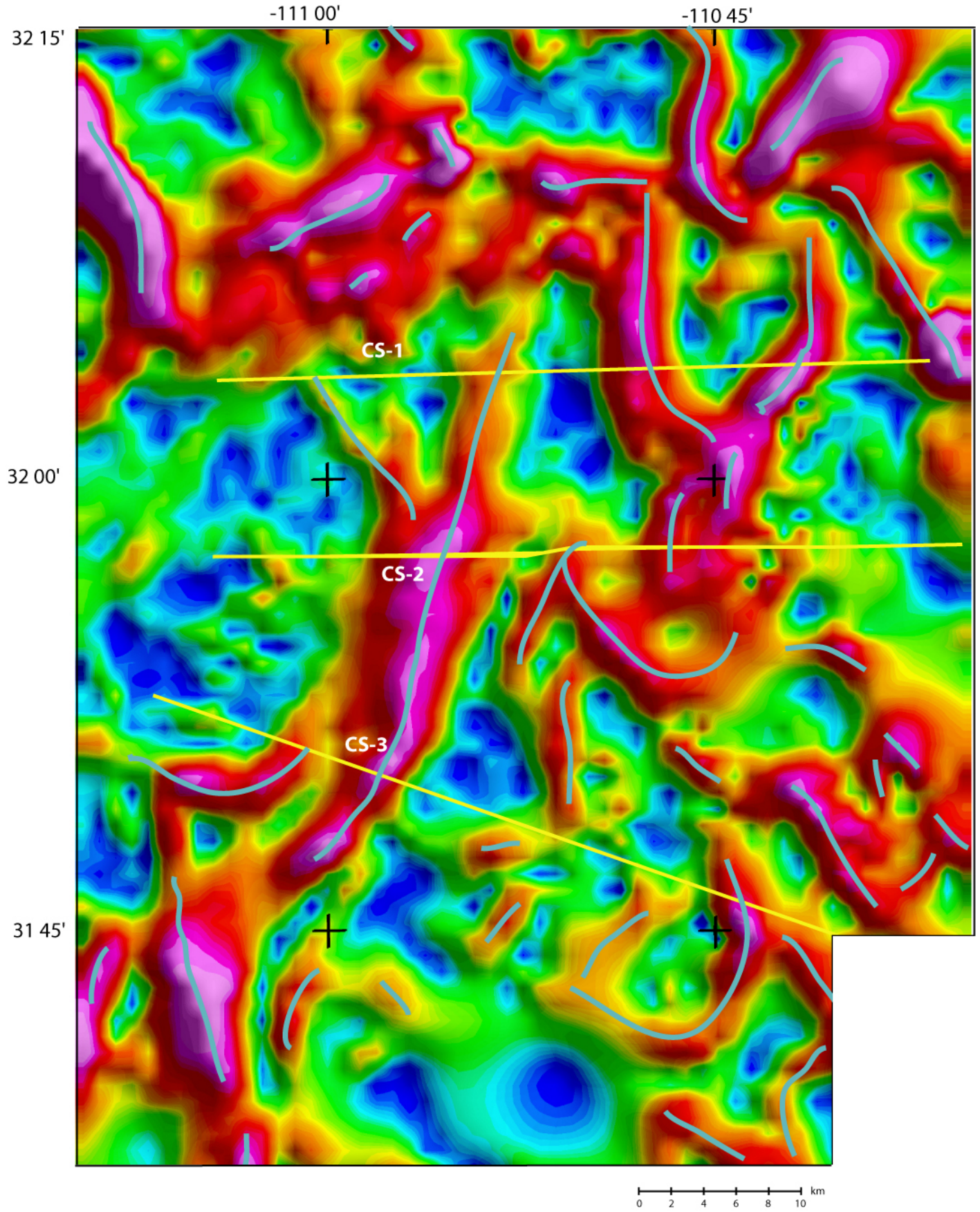

Figure 3.3: Maximum horizontal gradient of the Bouguer gravity data. Blue lines locate traces of the maximum gradient ridges that indicate steep density boundaries, and possible edges of bodies. 


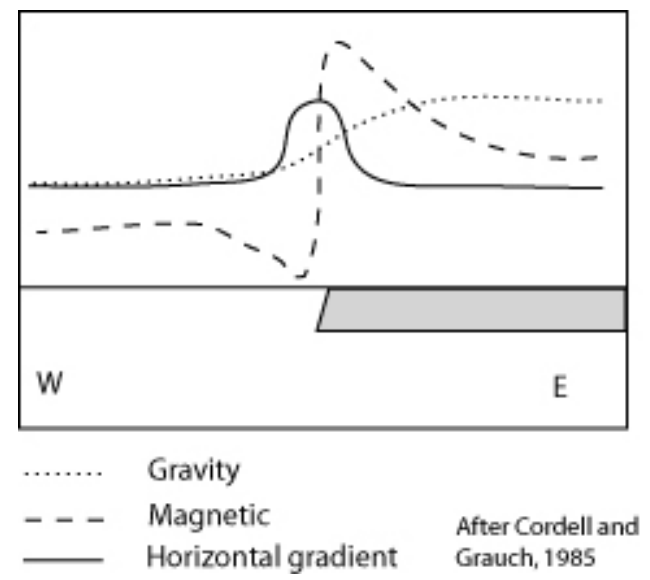

Figure 3.4: Cartoon of gravity and magnetic anomalies and the amplitude of the horizontal gradient over a contact between a dense, magnetic layer (shaded) and surrounding rocks, illustrating that the horizontal gradient is a maximum over the contact.

Aeromagnetic data

Three aeromagnetic surveys were flown from 1996 to 1999 in southeastern Arizona (Sweeney and Hill, 2001), two at a height of 150m and one at a height of $230 \mathrm{~m}$ above the terrain, along lines spaced $400 \mathrm{~m}, 150 \mathrm{~m}$ and $250 \mathrm{~m}$ apart. The surveys were designed to have a flight height to line spacing ratio close to 2 to 1 to avoid aliasing due to 3-D sources at the surface (Reid, 1980). Aliasing occurs when interpolation of the profile data onto a grid produce lower frequency anomalies than what is actually produced by the source. Low height to line spacing ratios also increase the confidence in the type of derivative processing methods used in this work (Reid, 1980). The Definitive Geomagnetic Reference Field (DGRF) calculated for the date of the original survey was removed, and the data were microleveled, reducing artificial trends and anomalies caused by flight noise. All data were upward continued to $230 \mathrm{~m}$ above the terrain and gridded at a 100 meter interval (Sweeney and Hill, 2001) (Figure 3.5). 


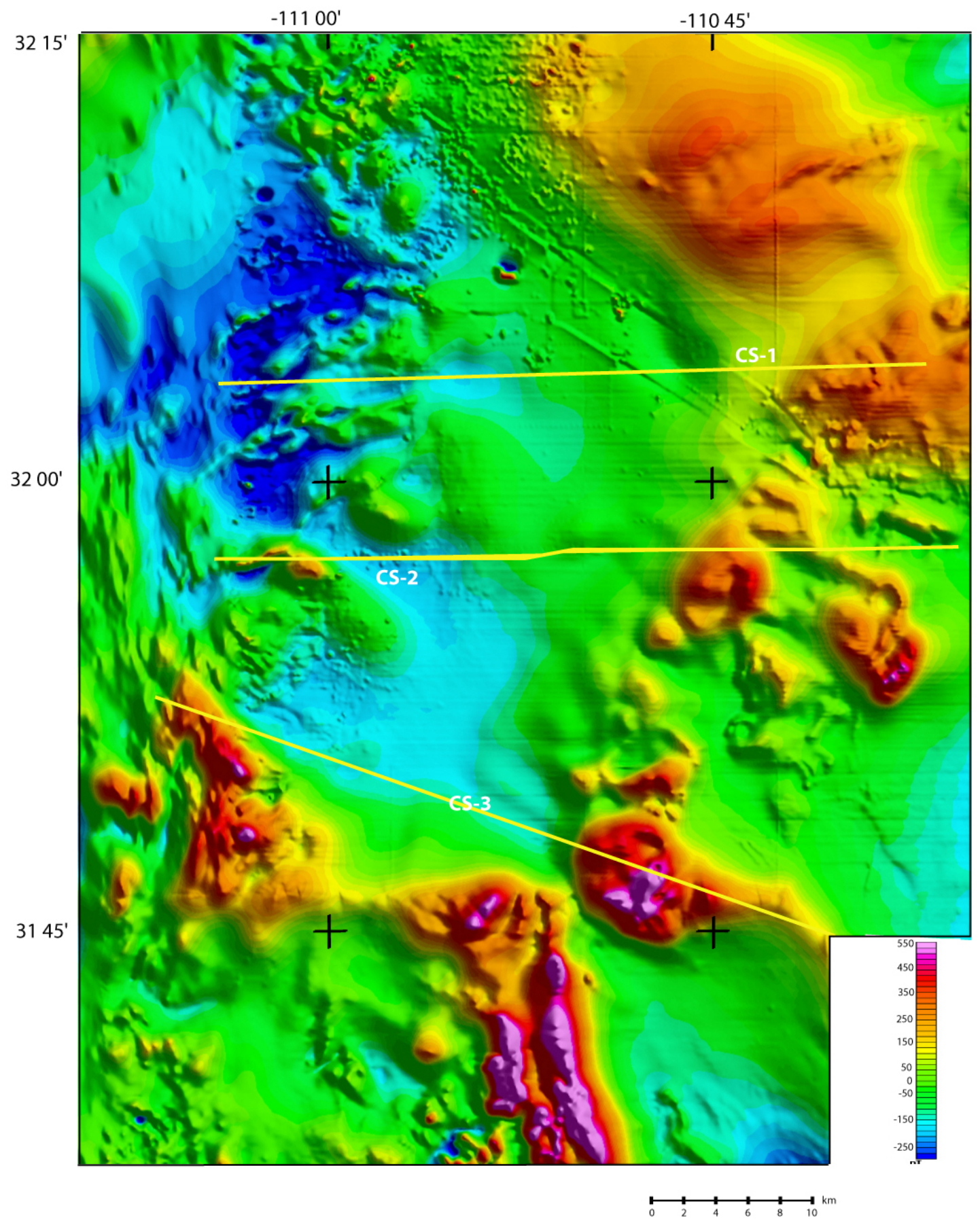

Figure 3.5: Reduced-to-the-Pole aeromagnetic map. Yellow lines show locations of model cross sections. 
To enhance the magnetic map and aid in geologic and tectonic interpretation, we applied several derivative processing methods to the magnetic data. The reduction-tothe-pole transform corrects total field anomalies in the total field for magnetic inclination and shifts the magnetic anomaly over the source body. This transform alters the shape of the anomaly such that symmetrical sources produce symmetrical anomalies (Baranov and Naudy, 1964). Induced magnetization is assumed for this transformation. This assumption is reasonable for most of the intrusive rocks in the region, large batholiths typically do not have large remanent magnetization because as a batholith cools the magnetite domains align themselves to magnetically cancel each other (Reynolds, Rosenbaum, and others, 1990). The volcanic rocks in the region, however, do possess significant remanent magnetization; the reduced-to-thepole transform, therefore, might not accurately shift these anomalies over their sources.

The pseudogravity transformation converts the total-field magnetic anomaly into the gravity anomaly that would be observed if an identical density distribution replaced the magnetic distribution (Figure 3.6) (Blakely, 1995). The usefulness of this transformation is that gravity anomalies have properties that simplify resolving the shape of the body causing the anomaly. Maximum horizontal gradients can also be computed for pseudogravity, defining the edges of steep magnetic bodies (figure 3.7). 


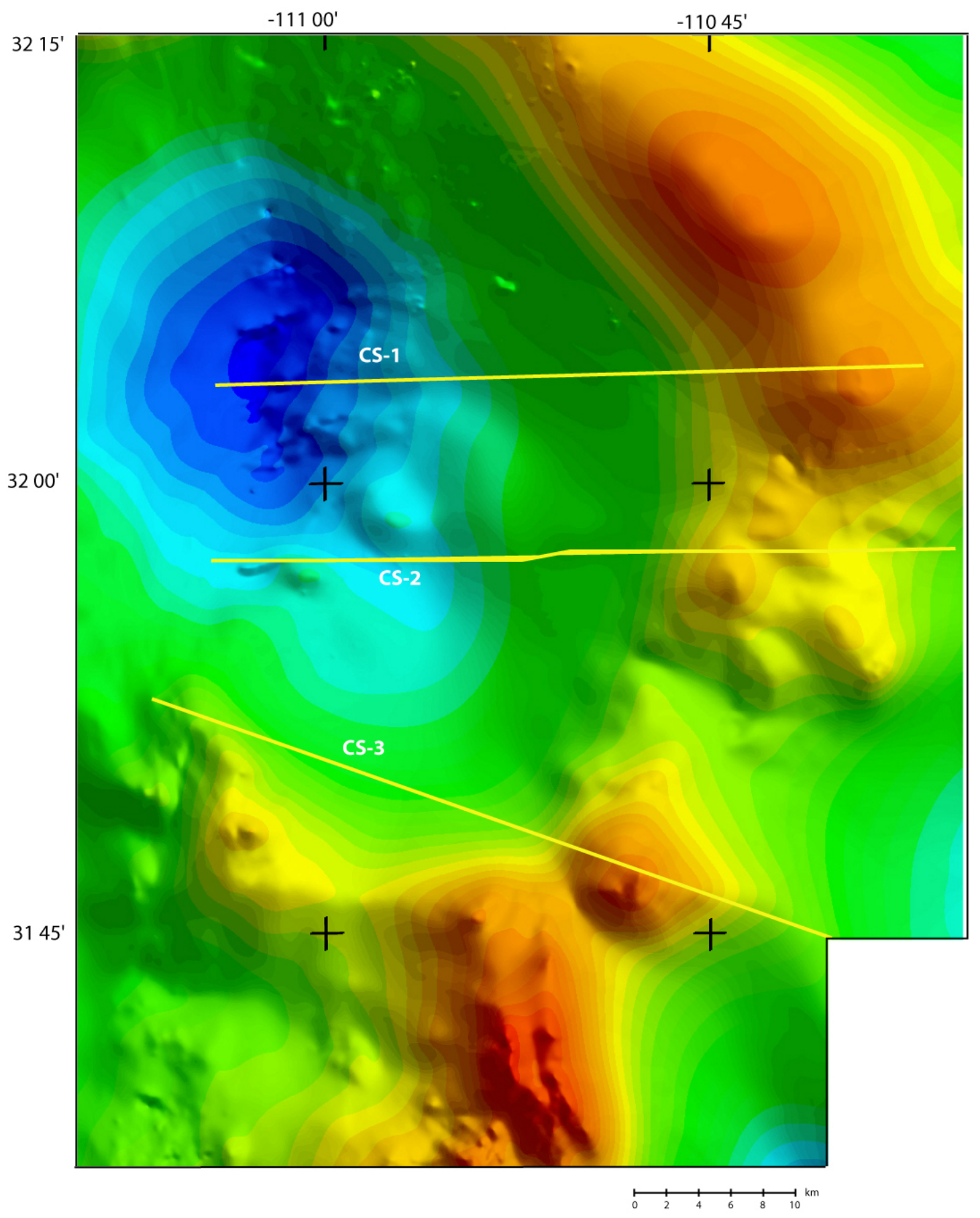

Figure 3.6: Pseudogravity from Reduced to the pole aeromagnetic data, calculation described in text. Yellow lines show location of model cross sections. 


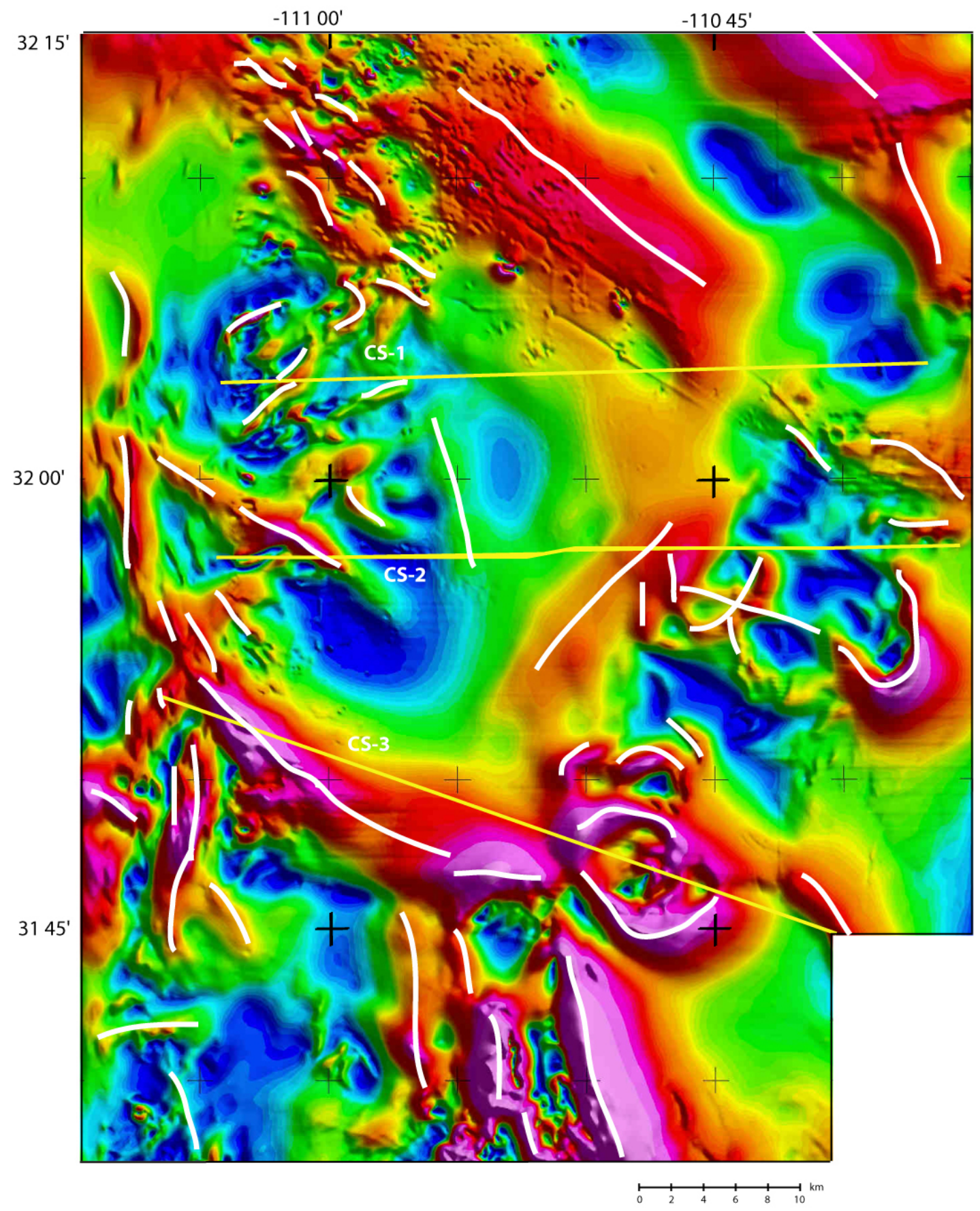

Figure 3.7: Map of the maximum horizontal gradient of the pseudogravity map. White lines are traces of the maximum horizontal gradients, to be discussed later. Yellow lines show locations of model cross sections. 


\section{Chapter 4 \\ ANOMALY IDENTIFICATION:}

Gravity Map

In order to aid in interpretation of the sources of the Bouguer gravity anomaly map, I compare the anomalies to mapped geology. A relative Bouguer gravity high of 25-35 mGals is associated with the areas surrounding the Tucson Basin from the east all the way counter-clockwise to the southwest. Major gravity highs are associated with mapped plutonic and volcanic outcrop. The oval shaped high (Figure 4.1, A) over the Tumacaccori Mountains corresponds to a Jurassic granite and quartz monzonite plutonic stock. To the north, a Late-Tertiary granitoid and quartz monzonite stock produces a gravity high over the Sierrita Mountains (Figure 4.1, B). Further north, small outcrops of Tertiary quartz latite porphory (Figure 4.1, C, pink) Cretaceous quartz monzonite (Figure 4.1, C, blue) and a small Jurassic rhyolitic porphory pluton outcrop (Figure 4.1, C, green) all probably contribute to the largeamplitude gravity high over the Tucson Mountains. To the east a Precambrian twomica gneiss is associated with a gravity low (Figure 4.1, D1, gray), and a Precambrian granodiorite is associated with a high (Figure 4.1, D2, gray). To the south highs can be correlated with Laramide quartz monzonite and granodiorite (Figure 4.1, E, blue).

The central and southeastern portions of the map have relatively low (20 mGals) gravity anomalies. The central north-northeast trending 15-20 mGal low is associated with the relatively low density sedimentary rocks of the Tucson Basin (Figure 4.1, F). The northeast-trending $\sim 10 \mathrm{mGal}$ low south of the Tucson Basin low (Figure 4.1, G) is related to the Amado subbasin (Gettings and Houser, 1997). To the southwest (Figure 4.1, E2, gray) Precambrian Continental Granodiorite is associated 

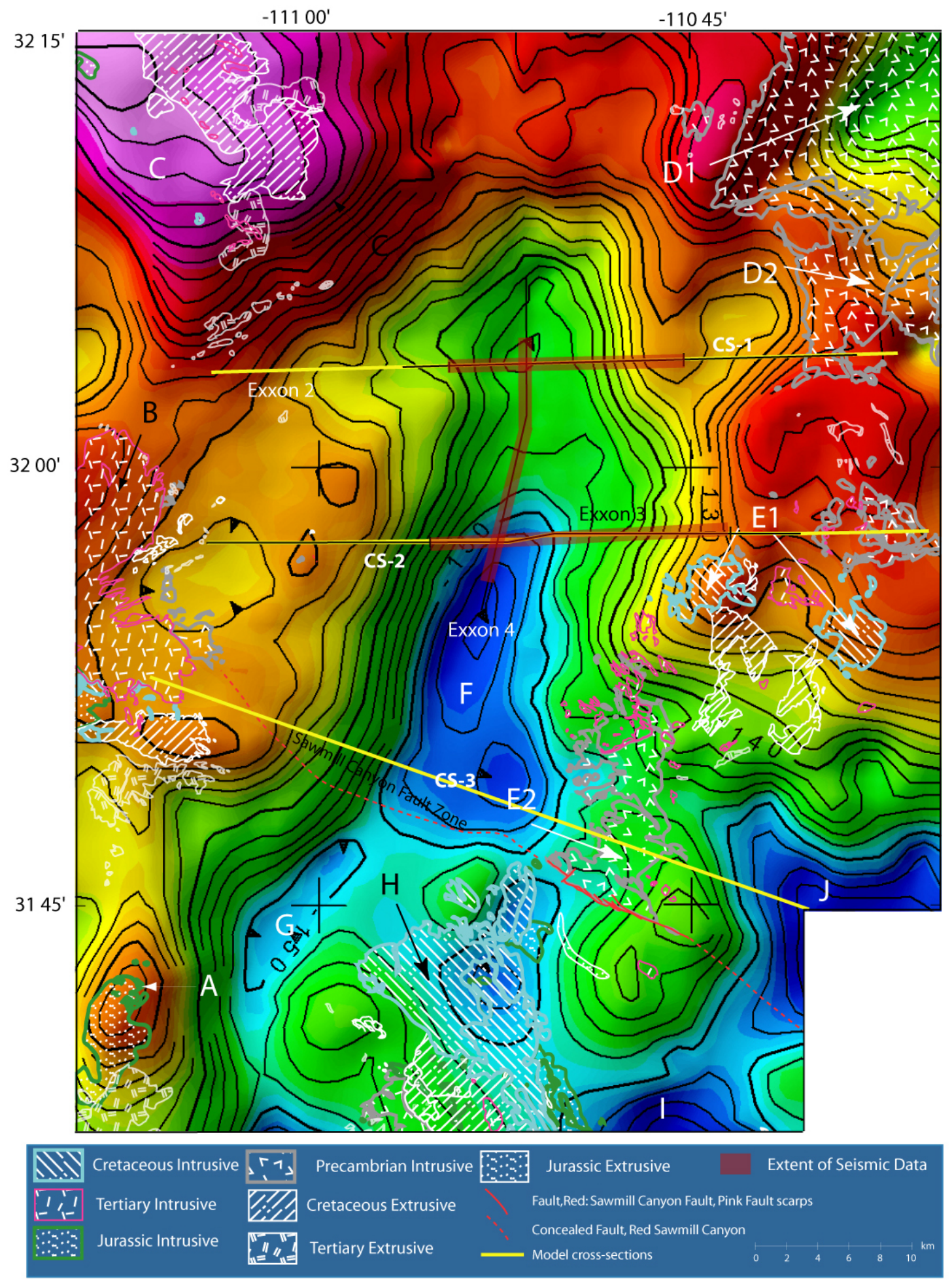

Figure 4.1: Bouguer gravity anomalies overlain by polygons representing selected geologic units. Letters are discussed in the text. Contours are 2 mGals. 
with gravity lows as well as the (Figure 4.1, H, blue) Laramide diorite and quartz monzonite. Of the two lows in the southeast portion of the map one is associated with Triassic and Cretaceous volcaniclastic sedimentary rocks (Figure 4.1, I) and the other is covered with Quaternary sediment (Figure 4.1, J) and the source is unknown.

\section{Aeromagnetic Map}

In order to determine the sources of magnetic anomalies, polygons delineating geologic units with magnetizations high enough to produce magnetic anomalies at the height of the surveys (Telford, Geldart, and others, 1976) are overlain on the reduced to the pole magnetic map (Figure 4.2). Magnetic susceptibility measurements from the region and values from the literature (Table 1) aid in the identification of magnetic units. Susceptibilities of normally and reversely magnetized mid-Tertiary volcanic rocks range from 0.13 to $0.15 \mathrm{SI}(0.17 \mathrm{SI}$ average andesite referenced from Telford, Geldart, and others, 1976). The susceptibilities of Early Cretaceous-Late Tertiary granitoids vary from the western side of the basin to the eastern side. The Ruby Star Granodiorite of the Sierrita Mountains has a susceptibility of 0.002-0.0035 SI while the Piper Gulch Monzonite of the Santa Rita Mountains is an order of magnitude more susceptible with 0.0219-0.031 SI. Jurassic granites, which are mostly reversed, are found to have low susceptibilities ranging from 0.00666 SI to $0.1288 \mathrm{SI}$. Precambrian Continental Granodiorite is estimated to have a low susceptibility around 0.00035 SI (Baldyga, 2001). 


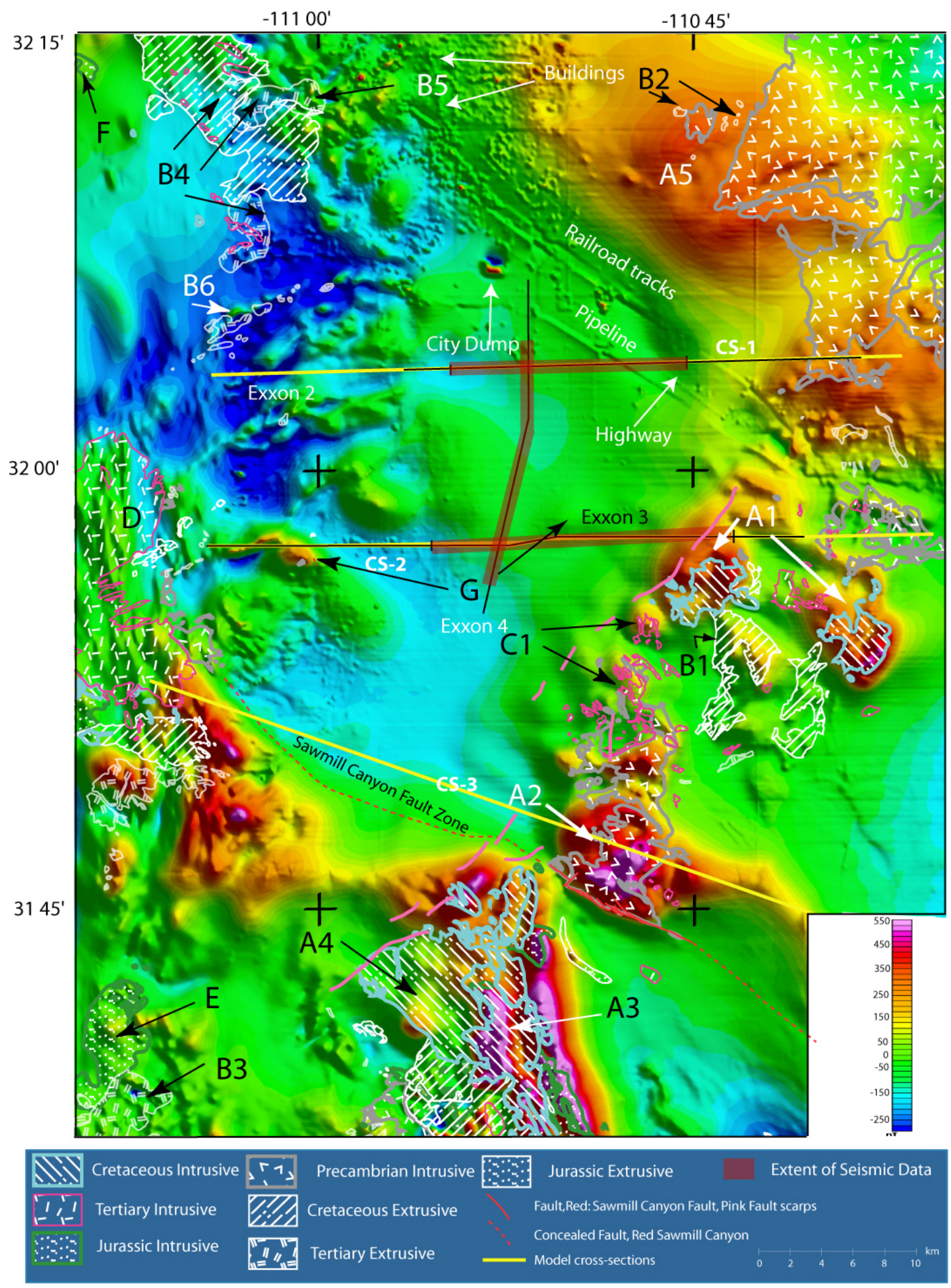

Figure 4.2: Reduced-to-Pole Aeromagnetic anomaly identification. Letters are discussed in the text. Human generated anomalies are labeled. 


\begin{tabular}{|c|c|c|c|c|}
\hline Map Unit & Lithology & Susceptibility & $\begin{array}{c}\text { Remnant } \\
\text { Polarity }\end{array}$ & Age \\
\hline $\mathrm{Tv}$ & & & & $30-20 \mathrm{Ma}^{1}$ \\
\hline Tva & $\begin{array}{c}\text { Black } \\
\text { Mountain } \\
\text { andesites }\end{array}$ & $0.17 \mathrm{SI}^{7}$ & $\mathrm{R}^{5}$ & $31-24 \mathrm{Ma}^{1}$ \\
\hline Tlv & $\begin{array}{c}\text { Tucson } \\
\text { mountain } \\
\text { rhyolite }\end{array}$ & & & $61 \mathrm{Ma}^{1}$ \\
\hline $\operatorname{Trv}$ & $\begin{array}{l}\text { rhyodacite } \\
\text { laccoliths \& } \\
\text { dikes }\end{array}$ & & $\mathrm{R}$ & $27,27 \mathrm{Ma}^{1}$ \\
\hline $\begin{array}{c}\text { Tgdu \& } \\
\text { Tgd }\end{array}$ & rhyodacite & & $\mathrm{R}$ & \\
\hline $\operatorname{Tlg}$ & $\begin{array}{l}\text { Ruby Star } \\
\text { Granodiorite }\end{array}$ & $0.0035 \mathrm{SI}^{6}$ & & $60-52 \mathrm{Ma}^{1}$ \\
\hline Tgr & rhyolite & & $\mathrm{N}$ & $26 \mathrm{Ma}^{1}$ \\
\hline Klp & $\begin{array}{l}\text { quartz latite } \\
\text { porphyry }\end{array}$ & $\begin{array}{c}0.0002 \text { SI } \\
\text { (SD: } 0.00004)\end{array}$ & $\mathrm{N}$ & \\
\hline $\mathrm{Kj}$ & $\begin{array}{l}\text { Josephine } \\
\text { Canyon } \\
\text { diorite }\end{array}$ & $\begin{array}{c}0.0302 \mathrm{SI} \\
(\mathrm{SD}: 0.0028) \\
0.002 \mathrm{SI} \\
(\mathrm{SD} 0.001) \\
\end{array}$ & $\mathrm{N}$ & $\sim 63 \mathrm{Ma}^{2}$ \\
\hline Keq & $\begin{array}{l}\text { Elephant } \\
\text { Head quartz } \\
\text { monzonite }\end{array}$ & $\begin{array}{c}0.0358 \mathrm{SI} \\
\text { (SD: } 0.0056) \\
0.0049 \mathrm{SI} \\
\text { (SD: } 0.0007)\end{array}$ & $\mathrm{R}$ & $68 \mathrm{Ma}^{1}$ \\
\hline $\operatorname{Trp}$ & $\begin{array}{l}\text { Piper Gulch } \\
\text { monzonite }\end{array}$ & $\begin{array}{c}0.0263 \mathrm{SI} \\
\text { (SD: } 0.0044)\end{array}$ & $\mathrm{N}$ & $188 \pm 2 \mathrm{Ma}^{3}$ \\
\hline Js & $\begin{array}{c}\text { Squaw } \\
\text { Gulch } \\
\text { granite }\end{array}$ & $\begin{array}{c}0.0072 \mathrm{SI} \\
(\mathrm{SD}: 0.00054) \\
0.0116 \mathrm{SI} \\
(\mathrm{SD}: 0.00128)\end{array}$ & $\mathrm{R}$ & $141 \mathrm{Ma}^{1}$ \\
\hline Yc & $\begin{array}{c}\text { Continental } \\
\text { Granodiorite }\end{array}$ & $0.00035 \mathrm{SI}^{4}$ & & $1450 \mathrm{Ma}^{1}$ \\
\hline
\end{tabular}

Table 1: Measured susceptibilities, remnant magnetization and ages of plutonic and volcanic rocks. Data from Gettings, (2002)unless otherwise noted. ${ }^{1} \mathrm{~K}$ Ar, Drewes, (1971), ${ }^{2} \mathrm{~Pb}-\alpha$, Drewes, (1971), ${ }^{3}$ Asmerom (1988), this date reassigns the unit to the Early Jurassic, ${ }^{4}$ Baldyaga, (2001), ${ }^{5}$ Percious, (1968), ${ }^{6}$ Walker, (1982), ${ }^{7}$ Average Andesite, Telford, et al, 1976.. Units from Drewes, (1971), Mt. Wrightson quadrangle 1:48000. SD-Standard Deviation, average number of samples 5 . 
Some features on the map are not caused by geological sources. Linear northwest striking anomalies correspond to railroad tracks, pipelines and Highway 89 (figure 4.2). Buildings and other city features cause short-wavelength dimples.

Trends, wavelengths, and amplitudes of magnetic anomalies can help determine their sources. Positive magnetic anomalies (250 to $450 \mathrm{nT}$ ) represent normally magnetized sources, such as dikes, granitic intrusions, volcanic flows, tuffs, and volcano-clastic units; low anomalies (-100 to $-250 \mathrm{nT})$ characterize non-magnetic sedimentary and metamorphic rocks in the region reverse-polarity magnetic sources, or the dipole of a positive anomaly. Where positive anomalies correlate with high topography, the rocks are probably normally magnetized. As well, low anomalies in high terrain suggest reversed magnetic rocks (Grauch, Sawyer, and others, 1997). When there is lack of correlation with topography or mapped geology, the possibility of buried sources arises.

Broad magnetic highs in the region primarily correspond to intrusive rocks of various ages. The high-amplitude, northeast-trending positive magnetic anomalies on the east side of the Tucson Basin primarily correlate with magnetic (Table 2) Laramide-age (Late Cretaceous-Early Tertiary) granodiorites/diorite intrusions as described in detail below. Laramide quartz monzonite and granodiorite outcrops correspond to nearly 300nT highs in the Santa Rita Mountains (Figure 4.2, A1). Just to the south, extrusive andesitic to dacitic volcanic breccias (Figure 4.2, B1, white) are associated with highs ranging from 50-150 nT. Quartz latite porphyry intrusions (Figure 4.2, C1, pink) also correspond to magnetic highs. Further south, highs on either side of the Sawmill Canyon Fault seem similar in amplitude and texture; 
however, the mapped geology is very different. Precambrian Continental Granodiorite (Figure 4.2, A2) is associated with the northern anomaly, while Cretaceous-Tertiary Josephine Canyon Diorite, is linked to the southern anomaly (Figure 4.2, A3). To the west (Figure 4.2, A4) the reversely magnetized (Gettings, 2002) Cretaceous-Tertiary Elephant Head Quartz Monzonite is associated with a moderate amplitude negative magnetic anomaly. The similarity of the magnetic anomalies A2-A3, the low magnetic susceptibilities of the Precambrian granodiorite (Baldyga, 2001) and their lack of correlation with magnetic anomalies elsewhere suggest that the source of anomaly A2 is a buried Laramide-age granodiorite/diorite and not the surficial Precambrian rocks. The similar north-west trending long wavelength positive anomaly to the north (Figure 4.2, A5) is partially associated with a low susceptibility Precambrian granodiorites and gneiss. No Laramide-age intrusive rocks crop out in this area, however there are two small outcrops of mid-Tertiary andesites (Figure 4.2, B2), but the wavelengths of the positive anomaly are too long to be related to these shallow volcanic rocks. This is the same high previously identified as a possible Laramide-age intrusion. (Sauck, Sumner, and Christensen, 1971).

In contrast to the Laramide-age intrusions, the Mid-Tertiary Ruby Star Granodiorites (Figure 4.2, D) in the Sierrita Mountains do not seem to be associated with high-amplitude positive anomalies like those of the Santa Rita Mountains, but with moderate amplitude anomalies ranging from $150 \mathrm{nT}$ to $-250 \mathrm{nT}$. A reversely magnetized (Gettings, 2002) Jurassic intrusion in the northern Tumacacori Mountains (Figure 4.2, E) is associated with moderate- frequency and amplitude magnetic lows 
(-50 to $50 \mathrm{nT}$ ). Over the Tucson Mountains a broad positive anomaly (Figure 4.2, F) correlates with a small outcrop of a Jurassic-Triassic rhyolitic porphyritic dike. However this is probably not the source, because a dike is not wide enough to produce such a broad anomaly.

Volcanic rocks in the region often produce high-frequency positive and negative magnetic anomalies. Andesitic volcanic fields in the Tumacaccori Mountains (Figure 4.2, B3) are associated with positive and negative magnetic anomalies, reflecting normally and reversely magnetized volcanic rocks (Gettings, 2002) erupted during multiple episodes. The reversely magnetized CretaceousTertiary (Laramide) rhyodacite tuff, breccia, and volcanics (Figure 4.2, B4) (Gettings, 2002) correspond to magnetic lows ( $-250 \mathrm{nT}$ to $-50 \mathrm{nT})$, and younger Oligocene volcanic rocks correspond to positive anomalies (150nT to $0 \mathrm{nT}$, (Figure 4.2, B5)). The positive anomaly over Black Mountain (B6) is associated with Oligocene andesites. At the north edge of this anomaly is a small outcrop of reversely magnetized Turkey Track porphyry (Percious, 1968) dated at 46 Ma, and therefore probably associated with the reversed volcanic rocks to the north in the Tucson Mountains (Figure 4.2, B4). 


\section{Chapter 5}

\section{MODELING OF THE GRAVITY AND MAGNETIC DATA}

\section{Two Dimensional Modeling}

To determine the geometry of the Tucson Basin, the dip of the bounding faults, the density distribution of sedimentary basin fill, and the lithology of the basement, I modeled gravity and magnetic profiles with a $2-1 / 2$ dimensional forward and inverse gravity and magnetic modeling program (after Webring, 1985). The program uses profiles of gravity and magnetic observations (here taken from the grids shown in Figures. 4.1 and 4.2) and starting models consisting of body corners and density and susceptibility contrasts. I then adjusted the starting model so that its gravitational and magnetic anomalies fit the profiles of the observed data. In order to reduce edge effects, the bodies at the ends of the model sections were continued 3000 $\mathrm{km}$. Perpendicular to the profiles, the bodies were extended distances determined by their mapped geologic extents.

The geometry of the starting model was constrained by seismic reflection data (Roy Johnson, pers. comm, 2000) and well-logs where available. For the Tucson Basin, the starting model consisted of four sedimentary layers consisting of Pliocene and Pleistocene upper fill; Late/Mid-Miocene lower fill; the Early Miocene Pantano Formation; and denser pre-Miocene sedimentary rocks (Figure 5.1—well log).

The densities used in the models were obtained from outcrop and well-log data (Table 2). The Bouguer reduction density of $2670 \mathrm{~kg} / \mathrm{m}^{3}$ as measured in outcrops of granitoids throughout the area (Gettings, 1997) was assumed as the average for the models. Based on well log bulk density data (Figure 5.1) (Houser and 


\section{Stratigraphic Column of Exxon Well \#32}

Eberly \&

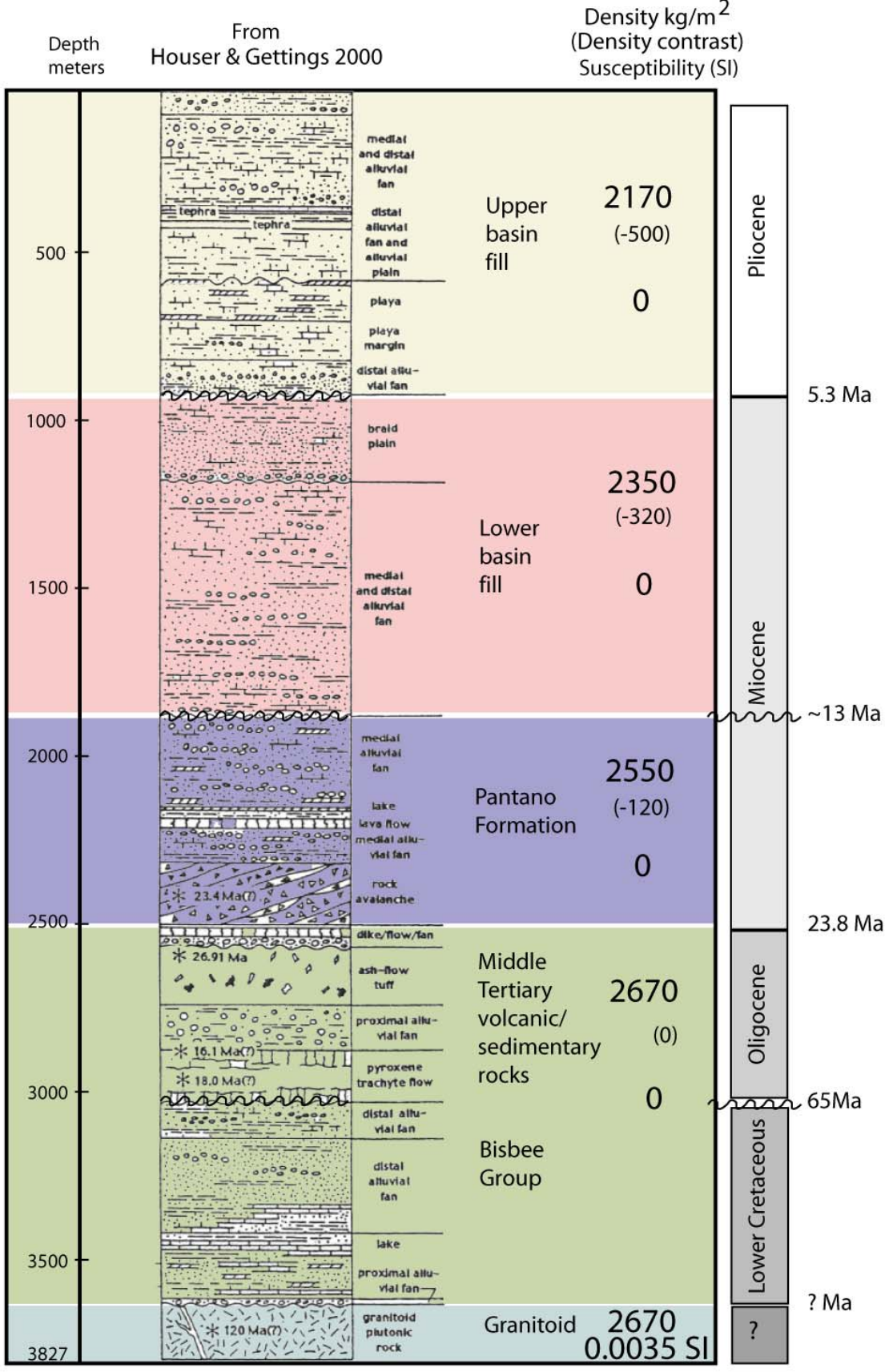

Figure 5.1: Exxon well (32) stratigraphic column after Houser and Gettings (2000). Densities averaged from well log, susceptibilities determined from modeling and samples (see text for more detail). Eberly and Stanley (1978) layer divisions for comparison. 


\begin{tabular}{|c|c|c|c|c|c|c|c|c|}
\hline \multirow{2}{*}{$\begin{array}{l}\text { Formation } \\
\text { Upper fill }\end{array}$} & \multirow{2}{*}{$\begin{array}{c}\text { Unit } \\
\text { Unit A } \\
\text { Unit B }\end{array}$} & \multicolumn{2}{|c|}{$\begin{array}{c}\text { Map Unit } \\
\text { Davidson, } 1973\end{array}$} & \multirow[t]{2}{*}{$\begin{array}{c}\text { Map } \\
\text { Unit } \\
\text { Drewes, } \\
1980 \\
\end{array}$} & \multirow{2}{*}{$\begin{array}{c}\begin{array}{c}\text { Density } \\
\text { range } \mathbf{~ k g} / \mathbf{m}^{3}\end{array} \\
2000-2300\end{array}$} & \multirow{2}{*}{$\begin{array}{c}\begin{array}{c}\text { Average } \\
\text { Density } \\
\mathbf{k g} / \mathbf{m}^{\mathbf{3}}\end{array} \\
2170\end{array}$} & \multirow{2}{*}{$\begin{array}{c}\begin{array}{c}\text { Density } \\
\text { Contrast } \\
\mathbf{k g} / \mathbf{m}^{3}\end{array} \\
-500\end{array}$} & \multirow{2}{*}{$\begin{array}{c}\begin{array}{c}\text { Susceptibility } \\
\text { (SI) }\end{array} \\
\quad \sim 0\end{array}$} \\
\hline & & $\begin{array}{l}\mathrm{Q} \\
\mathrm{Ts}\end{array}$ & $\begin{array}{l}\text { Fort Lowell } \\
\text { Formation }\end{array}$ & & & & & \\
\hline Lower Fill & $\begin{array}{l}\text { Unit C } \\
\text { Unit D }\end{array}$ & Tos & Tinaja beds & & $2250-2450$ & 2350 & -320 & $\sim 0$ \\
\hline Pantano Formation & & & & Tc & $2450-2550$ & 2500 & -170 & $\sim 0$ \\
\hline $\begin{array}{c}\text { Middle Tertiary } \\
\text { volcanic/sedimentar } \\
\text { y rocks }\end{array}$ & & & Tvs & & $2650-2750$ & 2700 & 30 & $\sim 0$ \\
\hline $\begin{array}{l}\text { Other sedimentary } \\
\text { rocks }\end{array}$ & & & & & & 2670 & 0 & $\sim 0$ \\
\hline Granitoid & & & & & $2550-2700$ & 2670 & 0 & $0.035-0.0035$ \\
\hline
\end{tabular}

Table 2: Exxon well (32) log bulk densities and susceptibilities: Densities from Houser and Gettings, 2000. 
Gettings, 2000), the density contrast between the sedimentary units below the Pantano Formation and the basement is zero. Therefore, I assume that the upper three bodies consisting of Miocene and younger sedimentary rocks produce the observed Bouguer gravity low (Figure 4.2). I assume that the magnetization of the sedimentary basin fill is zero because the possible magnetic anomaly from sediment is very small compared to underlying or nearby volcanic and igneous rock.

The separation into upper and lower basin fill was based on age, degree of consolidation, and the amount of deformation (Houser and Gettings, 2000). In southeastern Arizona's Basin and Range province, upper basin fill deposits are generally poorly to moderately consolidated, flat lying and only disturbed by a few small displacement faults (Houser and Gettings, 2000). The change from upper fill to lower fill is noted in the Exxon log as a change in bulk density from $2150 \mathrm{~kg} / \mathrm{m}^{3}$ (density contrast of $-520 \mathrm{~kg} / \mathrm{m}^{3}$ in the models) to $2350 \mathrm{~kg} / \mathrm{m}^{3}$ (density contrast of $320 \mathrm{~kg} / \mathrm{m}^{3}$ ) (Figure 5.1). The contact between the lower basin fill and the Pantano Formation is sharp, characterized by an increase in bulk density from $2350 \mathrm{~kg} / \mathrm{m}^{3}$ (density contrast of $-320 \mathrm{~kg} / \mathrm{m}^{3}$ ) to $2550 \mathrm{~kg} / \mathrm{m}^{3}$ (density contrast of $-120 \mathrm{~kg} / \mathrm{m}^{3}$ ) and an increase in seismic velocity from $3.3 \mathrm{~km} / \mathrm{s}$ to $4 \mathrm{~km} / \mathrm{s}$ (Houser and Gettings, 2000). This division is considered to mark the beginning of the Basin and Range extensional event at about 13-12 Ma (Houser and Gettings, 2000) (Roy Johnson, pers. comm., 2002).

Although the major portion of the fill of the basin consists of sedimentary rock, well logs reveal non-sedimentary rocks distributed within the sedimentary fill. Several wells hit layers of Tertiary volcanic rocks, welded tuff, and gypsum/anhydrite 
pockets. The gravity and magnetic perturbations caused by these other rocks are small because their thickness and lateral extent is limited. Therefore, in modeling the gravity and magnetic data, we have assumed that the density and magnetization contrasts between the sedimentary layers and the country rock are responsible for the first order shapes and amplitudes of the gravity and magnetic anomalies except in the case of magnetic anomalies where a body is close to the surface.

Combining known geologic data with seismic data helps to constrain the geologically feasible models derived from gravity and magnetic analysis. Well log data (Anderson, 1987; Davidson, 1973; Drewes, 1980; Houser and Gettings, 2000) and rock outcrops are mostly limited to the eastern edges of the three east-west model cross section lines. However, combining these data with the seismic cross sections constrains the interpretation of the model cross-sections. For example, a few well logs at the edges of the basin reach the Pantano Formation (Figure. 1.1) and crystalline basement. Correlation between the well logs (especially the Exxon (32)) and the seismic sections indicates that the top of the Pantano Formation is represented on the seismic sections as a sharp reflection that represents the transition between flat lying sedimentary units $(<13 \mathrm{Ma}$ ), and underlying faulted Pantano Formation (Figure. 1.1, purple). This correlation agrees with the division of Houser and Gettings (2000) and Johnson (oral communication, 2002). Eberly and Stanley (1978), however, interpreted that the strong reflection corresponded to the top of a lava flow below the Pantano Formation at a depth of $2.195 \mathrm{~km}$ (Figure 5.1), roughly 300 meters deeper than the interpreted depth from Houser and Gettings (2000). Houser and Gettings (2000) note that the sharpness of the increase of seismic velocities and densities 
logged in the Exxon well (32) suggest that the contact is probably an erosional unconformity representing a considerable hiatus and not the top of a lava flow. Although it is difficult to determine the exact source of the reflection, geologic lines of evidence support the interpretation as the top of the Pantano Formation. The Pantano Formation crops out near Black Mountain in the western portion of the basin (Figure 1.1) and in the Cienega Gap (Figure 1.1) at the eastern edge of the basin. Because the formation is at the surface on both sides of the basin, and under the lower fill in the basin, the formation would need to be faulted. Therefore the Pantano Formation must lie below the flat lying sedimentary structures represented on the seismic lines. This suggests that the strong seismic reflector represents the top of the Pantano Formation at $1.88 \mathrm{~km}$ depth at the location of Exxon well (32).

In addition to the difficulty in correlating the prominent seismic reflector with a specific rock unit, problems exist with correlating the depths determined from the well $\log$ with those that can be inferred from the seismic reflection profiles by applying reasonable seismic velocities. The two-way travel time to the prominent reflector inferred to represent the top of the Pantano formation is $1.8 \mathrm{~s}$ at the location of Exxon well (32). If the depth to the top of the Pantano Formation from the Exxon well (32) is $\sim 1880 \mathrm{~m}$, an average p-wave velocity of $2 \mathrm{~km} / \mathrm{s}$ is required for the basin fill units. While this seems low, the sonic logs from the Exxon well (32) show a highly variable range of $2 \mathrm{~km} / \mathrm{s}$ to $3 \mathrm{~km} / \mathrm{s}$, with an average of $2.4 \mathrm{~km} / \mathrm{s}$ for the upper fill and a range of 2.75 to $3.2 \mathrm{~km} / \mathrm{s}$, with an average of $3.15 \mathrm{~km} / \mathrm{s}$ for the lower fill. For the upper fill average velocity of $2.4 \mathrm{~km} / \mathrm{s}$ this places the bottom of the upper fill at $1.08 \mathrm{~km}$. The stratigraphic column (Figure 5.1) shows a depth to the bottom of the 
upper fill to be $0.8 \mathrm{~km}$ or $74 \%$ of the seismically estimated depth. The estimated depth to the top of the Pantano Formation using an average velocity of $2.78 \mathrm{~km} / \mathrm{s}$ results in an estimated depth of $2.5 \mathrm{~km}$. The Exxon well (32) depth estimate is 1.88 $\mathrm{km}$ or $75 \%$ of the seismic travel time estimate. The sources of error in correlating the depth estimates between the seismic sections and the Exxon well (32) can arise from uncertainties in parameters used in the seismic data processing. A 25\% error is not uncommon when using a constant velocity in the migration process (Lapinski, pers. comm., 2003). A velocity of $3 \mathrm{~km} / \mathrm{s}$ was used in this migration. Therefore, the seismic lines are used primarily to delineate the shape of the sedimentary layers for modeling and to identify the top of the Pantano Formation. In the following, I assume that the depth to the top of the Pantano is indeed $1.88 \mathrm{~km}$ (Gettings and Houser, 1997).

By assuming that the thickness of each sedimentary layer in the central part of the basin is a constant percentage of the total basin thickness as represented in the Exxon well (32), I can correlate the stratigraphic column from seismic line two (Figure 5.2) to seismic line three (Figures 5.3 and 5.4). By correlating the known depth of the top of the Pantano Formation with the strong reflection in the seismic line, we can show the approximate depth of the other layer divisions. The seismic lines were placed behind the cross section during modeling, and layer reflections were traced to obtain the shape of the interface between the top of the Pantano and lower fill and adjacent bedrock in the starting model. The location of the boundary between the upper and lower basin fill was inferred from the well logs. 


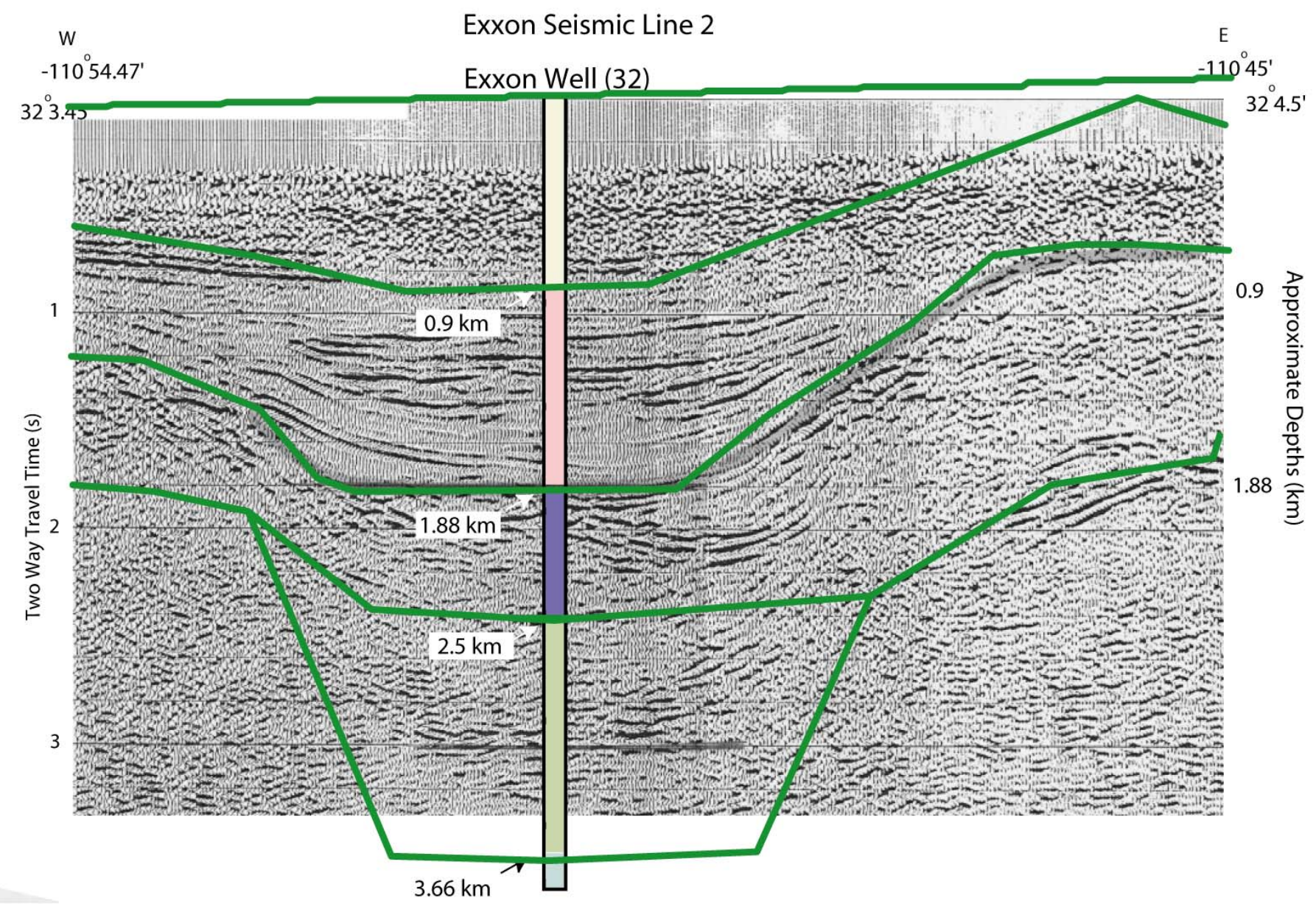

Figure 5.2: Exxon seismic line two. Green lines are modeled layer divisions shown in figure 5.5. Column is taken from divisions of Exxon well (32), figure 5.1. Seismic line two is coincident with cross section CS-1. The location is shown in red along cross section CS-1 in figure 1.1. The top of the Pantano Formation (blue) is correlated with the strong reflector (discussed more in text). 


\section{Exxon Seismic Line 3}

W

Exxon Line 4

E

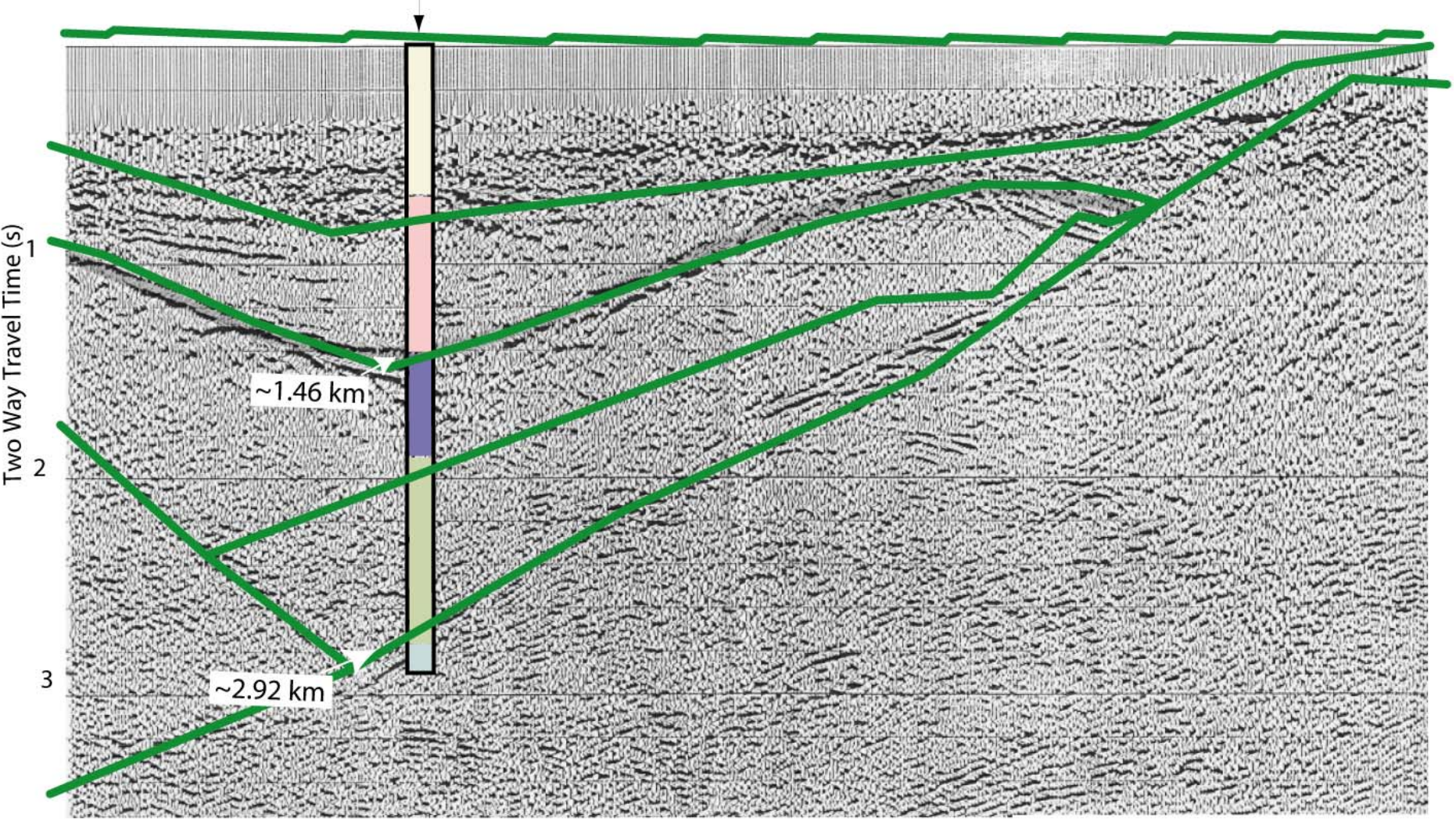

Figure 5.3: Exxon seismic line three. Green lines are modeled layer divisions shown in figure 5.7. Column is taken from divisions of Exxon well (32), figure 5.1. Seismic line three is coincident with cross section CS-2. The location is shown in red along cross section CS-2 in figure 1.1. The top of the Pantano Formation (blue) is correlated with the strong reflector (discussed more in text). 


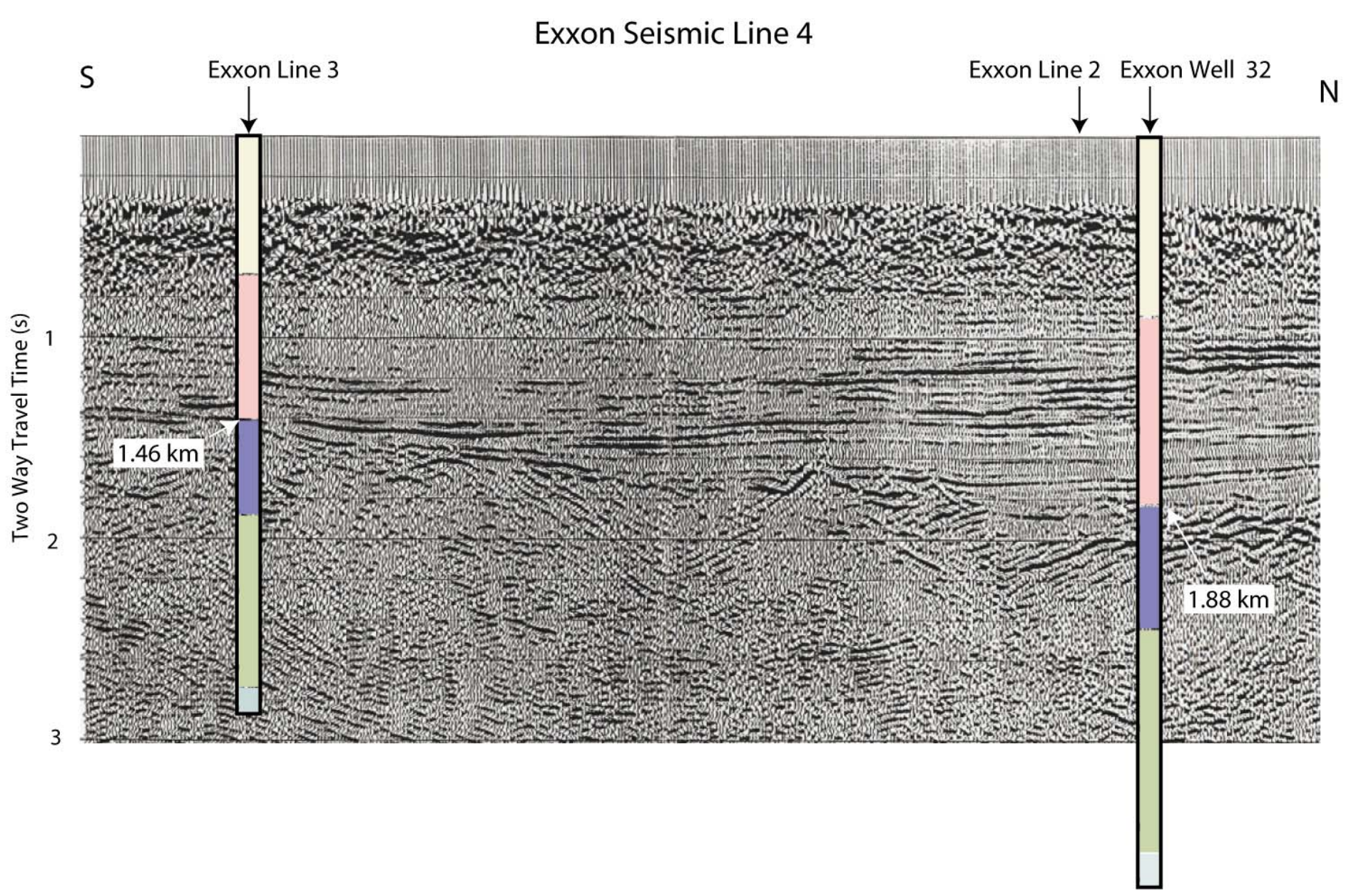

Figure 5.4: Seismic line four. The location is shown in red along north-south line in figure 1.1. Columns are proportional to the Exxon well (32) column in figure 5.1 with the top of the Pantano Formation aligned with the strong reflector (discussed more in text). 


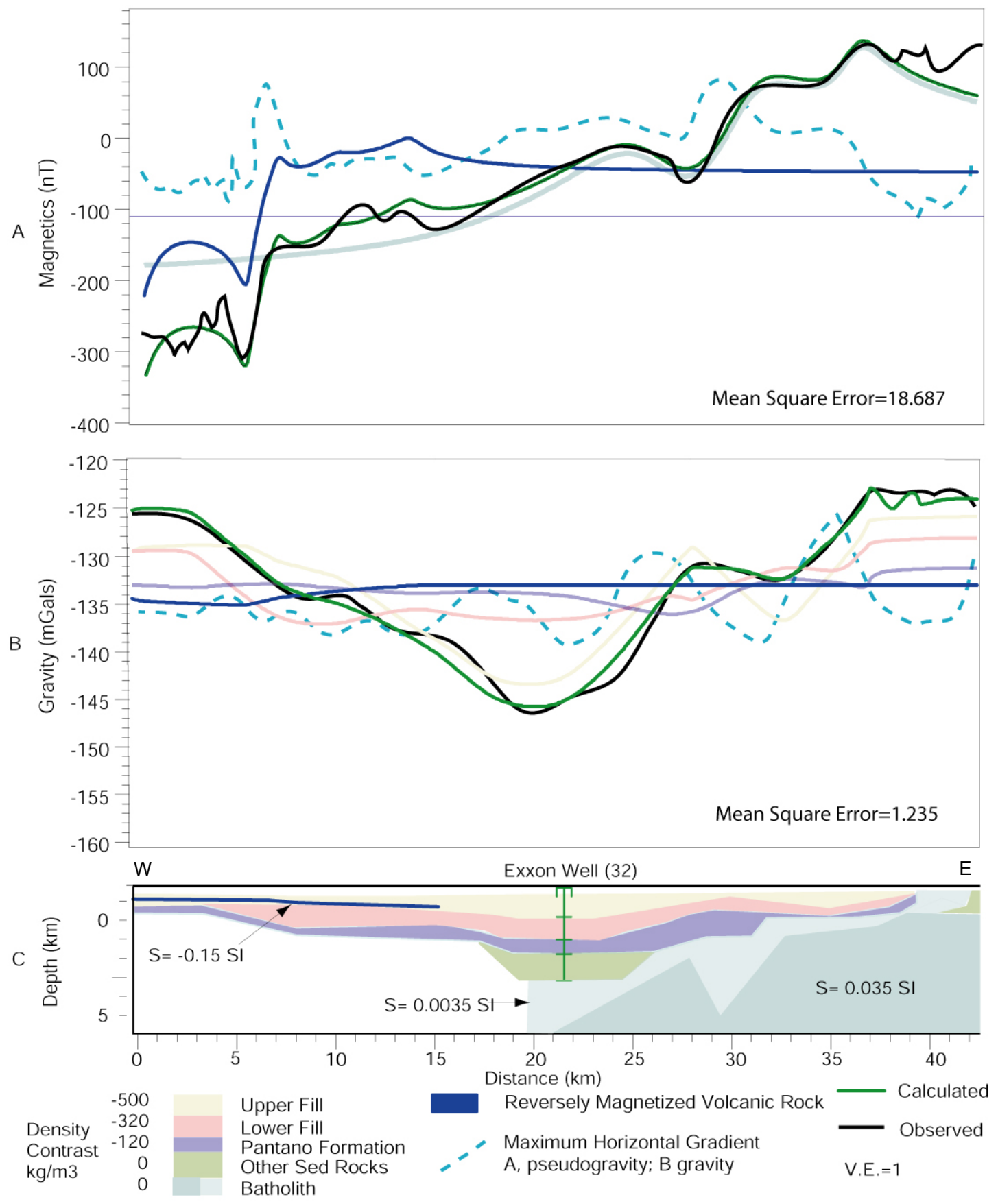

Figure 5.5: Cross section CS-1, location shown in Figure 1.1. A. Magnetic anomalies, solid lines respond to magnetic response from individual colored bodies in $\mathrm{C}$, dashed blue line is pseudogravity acquired from figure 3.7. C. Gravity anomalies, solid lines respond to gravitational response from individual colored bodies in C. C. modeled cross section. Colors correspond to layers derived from Exxon well (32) (figure 5.1). If not labeled, susceptibilities of bodies are zero (discussed more in text). 


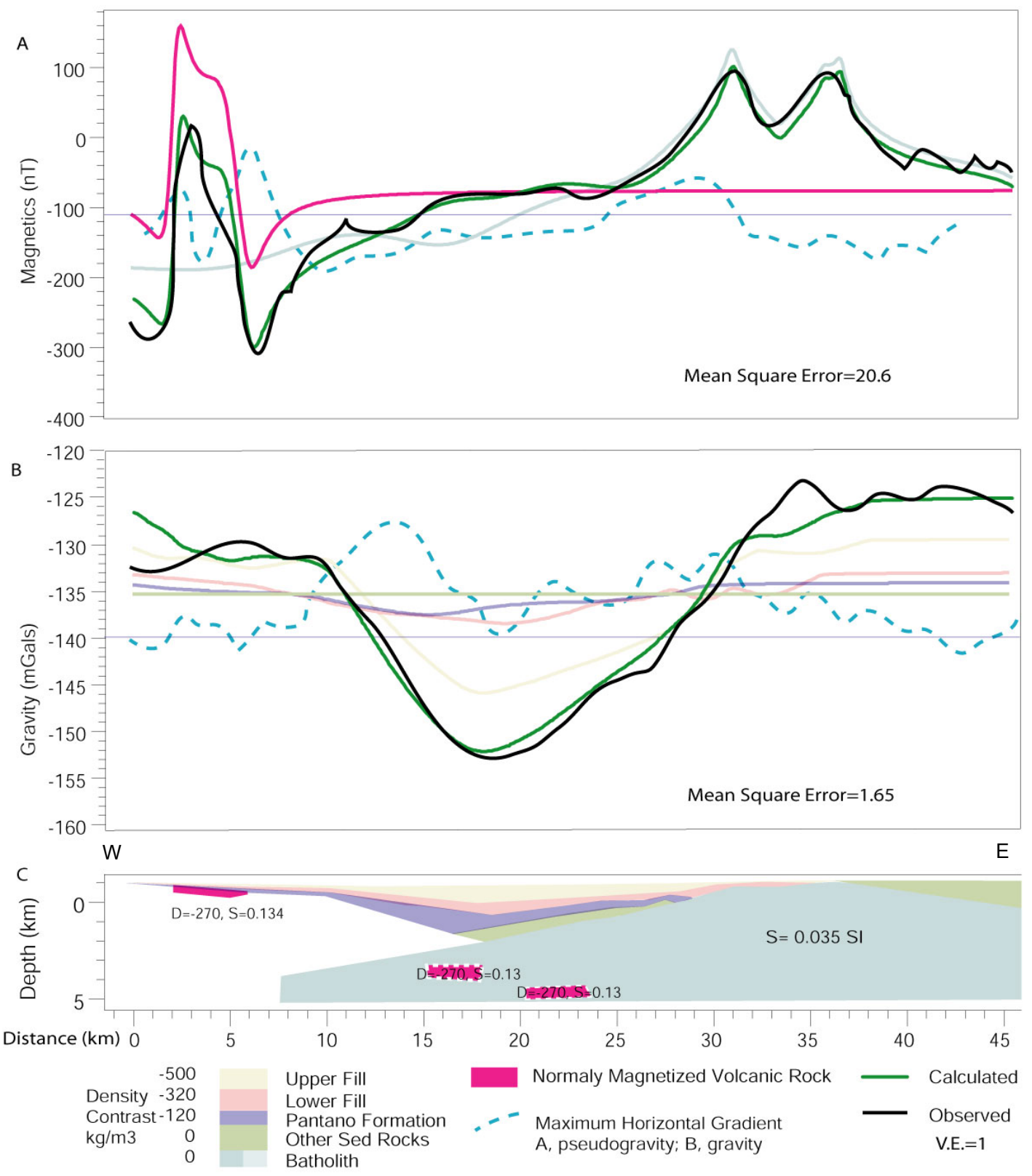

Figure 5.6: Cross section CS-2, location shown in Figure 1.1. A. Magnetic anomalies, solid lines respond to magnetic response from individual colored bodies in $\mathrm{C}$, dashed blue line is pseudogravity acquired from figure 3.7. C. Gravity anomalies, solid lines respond to gravitational response from individual colored bodies in C. C. modeled cross section. Colors correspond to layers assigned in Exxon well (32) (figure 5.1). If not labeled susceptibilities of bodies are zero (discussed more in text). 

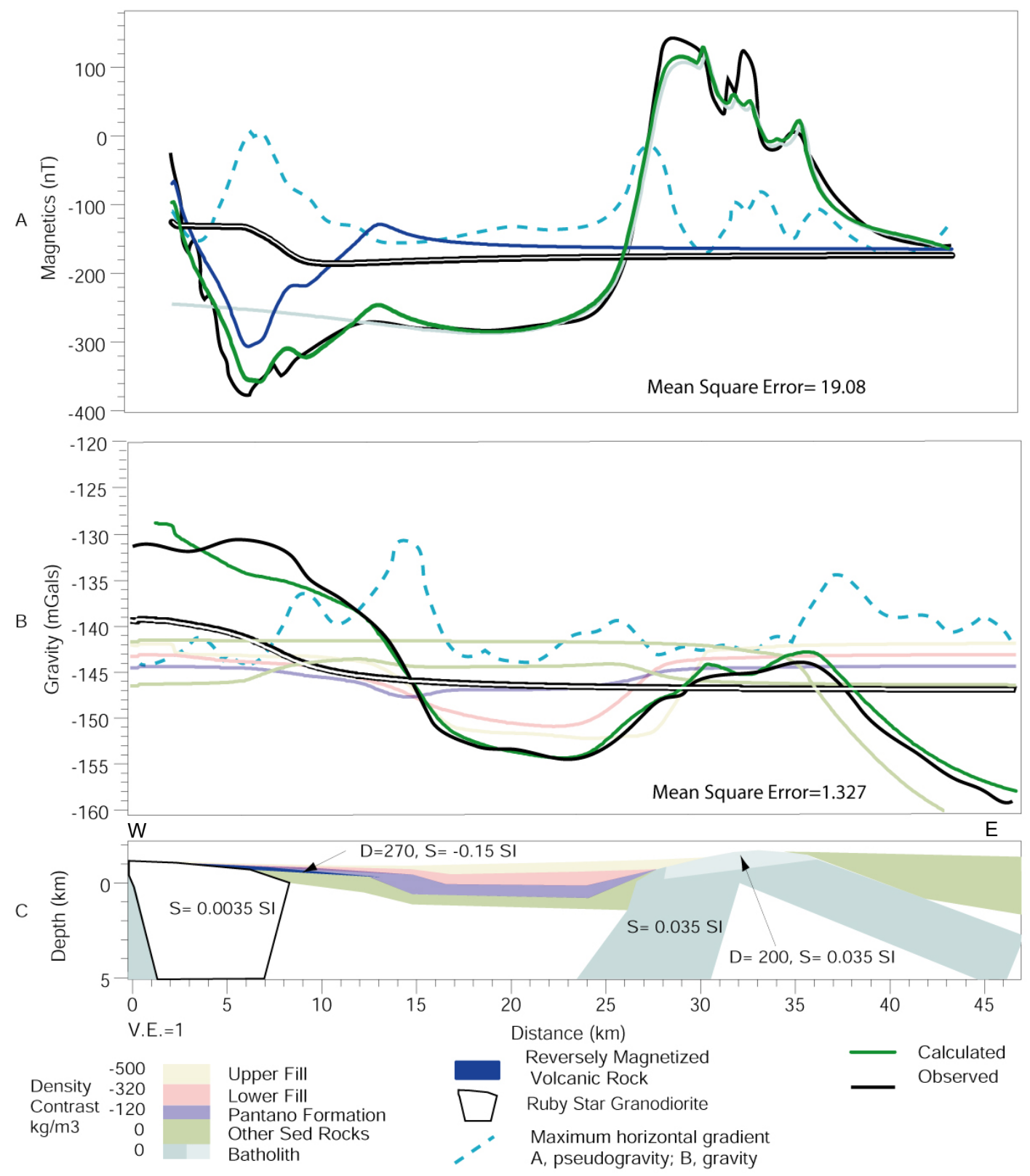

Figure 5.7: Cross section CS-3, location shown in Figure 1.1. A. Magnetic anomalies, solid lines respond to magnetic response from individual colored bodies in $\mathrm{C}$, dashed blue line is pseudogravity acquired from figure 3.7. C. Gravity anomalies, solid lines respond to gravitational response from individual colored bodies in C. C. modeled cross section. Colors correspond to layers assigned in Exxon well (32) (figure 5.1). If not labeled susceptibilities of bodies are zero (discussed more in text). 
For the magnetic modeling, several assumptions were made for the rock properties. In all cases, the magnetizations of the modeled bodies were assumed to be in the direction of the present Earth's field (inclination of $59^{\circ}$ and declination of $12^{\circ}$ with an intensity of $49000 \mathrm{nT}$ ). This assumption is reasonable for most of the intrusive rocks because their magnetization is largely induced (Reynolds, Rosenbaum, and others, 1990). This assumption however is not true for volcanic bodies as we can clearly see negative anomalies due to reversed rocks in the Tumacaccori Volcanic Field (B3, Figure 4.2).

Correlation of magnetic anomalies with outcrops of igneous and volcanic rocks as described above guided the selection of the rock types in the region that produce magnetic anomalies. Susceptibility measurements of dozens of igneous rocks (Gettings, 2002) suggest a range within which to restrict the modeling. Table 1 shows susceptibilities of some of the rocks in the study area. Magnetic bodies were placed below the modeled sedimentary layers and the susceptibilities were varied in order to fit the observed anomaly.

Figures 5.5-5.7 show the three model cross sections (c) and observed and calculated magnetic (a) and gravity profiles (b). The difference between the observed and calculated is given by the mean error on the figure. Figures 5.5 and 5.6 are modeled across the two east-west seismic lines and Figure 5.7 is to the south. For all cross sections, the lower crust (from 12km to a depth of 30km (Myers and Beck, 1994 ) is modeled with a density contrast of $280 \mathrm{~kg} / \mathrm{m}^{3}$, and a susceptibility of zero. The susceptibilities and density contrasts used for the crustal section above $12 \mathrm{~km}$ depth are shown in table 3. 


\begin{tabular}{|c|c|c|}
\hline Lithology & Susceptibility & $\begin{array}{c}\text { Density } \\
\text { Contrast }\end{array}$ \\
\hline $\begin{array}{c}\text { Tertiary } \\
\text { reversely } \\
\text { magnetized } \\
\text { volcanics }\end{array}$ & $-0.15 \mathrm{SI}$ & $-270 \mathrm{k} / \mathrm{m}^{3}$ \\
\hline $\begin{array}{c}\text { Tertiary } \\
\text { dikes }\end{array}$ & $0.13 \mathrm{SI}$ & $-270 \mathrm{k} / \mathrm{m}^{3}$ \\
\hline $\begin{array}{c}\text { Ruby Star } \\
\text { Granodiorite }\end{array}$ & $0.0035 \mathrm{SI}$ & $-30 \mathrm{k} / \mathrm{m}^{3}$ \\
\hline $\begin{array}{c}\text { Rincon and } \\
\text { Continental } \\
\text { Granodiorite }\end{array}$ & $0.0035 \mathrm{SI}$ & $0 \mathrm{k} / \mathrm{m}^{3}$ \\
\hline $\begin{array}{c}\text { Tertiary- } \\
\text { Cretaceous } \\
\text { quartz }\end{array}$ & $0.035 \mathrm{SI}$ & $0 \mathrm{k} / \mathrm{m}^{3}$ \\
granodiorite & 0 & $-150 \mathrm{k} / \mathrm{m}^{3}$ to \\
\hline $\begin{array}{c}\text { other } \\
\text { sedimentary } \\
\text { rocks }\end{array}$ & $000 \mathrm{k} / \mathrm{m}^{3}$ \\
\hline
\end{tabular}

Table 3: Susceptibilities and densities of rock units used in modeling excluding units from the Exxon well (32) log that are listed on Fig. 5.1.

Cross section CS-1 (Figure 5.5) partially coincides with Exxon seismic line 2 (Eberly and Stanley Jr., 1978). Outcrop of Precambrian Rincon Valley Granodiorite bounds the eastern edge of the model at the surface and has an assigned density contrast of zero and susceptibility of 0.003 SI. The body is on the upper plate of the detachment fault related to the Santa Catalina Metamorphic Core Complex and can be modeled as very thin $(500 \mathrm{~m})$. A sedimentary rock body (density contrast, -150 $\mathrm{kg} / \mathrm{m}^{3}$; susceptibility, zero) mostly Cretaceous in age is modeled to the east. The -13 mGal main gravity low over the Tucson Basin can be modeled as due to the negative density contrast between the intra-basin late Cenozoic sedimentary rocks and the adjacent denser country rock. The thicknesses and density contrasts taken from the Exxon well (32) (Figure 5.1) are: upper fill, $0.908 \mathrm{~km},-500 \mathrm{~kg} / \mathrm{m}^{3}$; lower fill, 0.972 
$\mathrm{km},-320 \mathrm{~kg} / \mathrm{m}^{3}$; Pantano Formation, $0.636 \mathrm{~km},-120 \mathrm{~kg} / \mathrm{m}^{3}$; other sedimentary rocks, $1.141 \mathrm{~km}, 0 \mathrm{~kg} / \mathrm{m}^{3}$. The effect of each layer's density contrast can be seen when the gravity response of each block is calculated. It is shown that the primary body responsible for the basin gravity anomaly is the upper fill (Figure 5.5b, yellow line), and that the deeper layers have decreasing affect on the gravity anomaly (Figure 5.5 $\mathrm{b}$, pink, and purple lines), with the pre-Oligocene rocks having no effect due to their lack of assigned density contrast with the adjacent rocks.

Increases in the dips of the interfaces at the edges of the basin are modeled at $17 \mathrm{~km}$ and $27 \mathrm{~km}$ along the profile. These changes in the dips are marked by peaks in the amplitude of the gravity maximum horizontal gradients (Figure 5.5b, dashed blue line; Figure 3.3). The third maximum horizontal gradient peak at $38 \mathrm{~km}$ along the cross section represents a steep contact between the sedimentary layers and the granitic outcrop with a dip of $65^{\circ}$. The basin is deepest from 18 to $26 \mathrm{~km}$ along the profile and the layers thin towards the edges. However, a thicker layer of the Pantano Formation is seen towards the east from 26 to $32 \mathrm{~km}$ along the profile.

The basement beneath the basin is modeled with two bodies. On the west, the body has zero density and magnetization contrasts. Based on the lack of high positive magnetic anomalies and outcrop distribution, a combination of Precambrian or Jurassic granitoid rocks and perhaps Paleozoic sedimentary rocks most likely correspond to this body, but the lithology is unconstrained by the modeling. In contrast, the eastern body produces a large $(150 \mathrm{nT})$ positive magnetic anomaly (anomaly A5, Figure 4.2) that can be modeled with 0 density contrast and susceptibility 0.035 SI (Figure 5.5,a, light blue line). The match of the modeled with 
measured susceptibilities in the region, corroborates the interpretation above that this body represents a Laramide diorite. This body begins at a depth of $1 \mathrm{~km}$ and thins as it dips to the west under the basin. In the eastern portion of the cross section it reaches a maximum thickness of $11 \mathrm{~km}$. The Exxon well (32) hits granitoid rock at $3.66 \mathrm{~km}$ depth (Figure 5.1) that is interpreted to be part of the Precambrian Oracle Granite exposed $15 \mathrm{~km}$ to the east in the Cienega Gap (Houser, pers. comm., 2002). Therefore in my model I connect the Precambrian granite outcrop at the surface to granite below the drill hole. It was shown previously that the Precambrian granites of this region have very low susceptibilities compared to the underlying Cretaceous/Tertiary igneous bodies, so it is modeled as zero density contrast, 0.0035 susceptibility. The sharp dip of the top of this body that begins at $32 \mathrm{~km}$ along the profile and bottoms out at $31 \mathrm{~km}$ along the profile is coincident with a peak in the amplitude of the pseudogravity maximum horizontal gradient (Figure 5.5, a, dashed blue line; Figure. 3.7). On the west side of the profile, the sedimentary section thins to $1 \mathrm{~km}$. At the surface, a thin reversely magnetized body is placed in the western edge of the basin that is $0.1 \mathrm{~km}$ thick with a density contrast of $-270 \mathrm{~kg} / \mathrm{m}^{3}$ and susceptibility, $-0.2 \mathrm{SI}$ (Figure 5.5, a, dark blue line).

Cross section CS-2 (figure 5.6) was modeled along Exxon seismic line three. To estimate the depths of this cross section's sedimentary rock layers, I correlated the sedimentary rock layers logged in the Exxon well (32) with the reflective horizons in Exxon seismic line three (Figure 5.3). This procedure is approximate, but gives a starting point for the modeling of the layer thicknesses. A mixture of Pinal Schist, Precambrian granite, Lower Cretaceous sedimentary rocks and small intrusions of 
Tertiary quartz latite porphyry bound the eastern edge of the cross section. I assume that the sedimentary rocks and the porphyry intrusions are thin compared to the thicknesses of the granitoids, based on the high amplitude positive gravity anomaly and lack of correlation between the porphyry and the magnetic signature. Therefore, I modeled the mix of rock types as one body with zero density contrast, zero susceptibility and a thickness of $1 \mathrm{~km}$. The magnetic profile above this area shows that a short wavelength magnetic body would help the profile fit, but my main interest was to model the main anomaly features.

The body primarily responsible for the negative $20 \mathrm{mGal}$ gravity anomaly is the upper fill (yellow line). However, the effect is much less than in cross section CS1 (Figure 5.5, b). Each lower layer is responsible for less of the anomaly (pink and purple lines) and the pre-Oligocene rocks have no effect (light green line). The layers are thinner in cross section CS-2 (where seismic line four intersects the cross section) than in cross section CS-1 (upper fill, $0.716 \mathrm{~km},-500 \mathrm{~kg} / \mathrm{m}^{3}$; lower fill, $0.744 \mathrm{~km}$, $320 \mathrm{~kg} / \mathrm{m}^{3}$; Pantano Formation, $0.48 \mathrm{~km},-120 \mathrm{~kg} / \mathrm{m}^{3}$; other sedimentary rocks, 0.99 $\mathrm{km}, 0 \mathrm{~kg} / \mathrm{m}^{3}$ ). The western side of the basin has an apparent steeper dip than the eastern side; this roughly correlates with the peak amplitude in the gravity maximum horizontal gradient (Figure 5.6, b, dashed blue line; Figure. 3.3). The layers thin towards the edges of the model.

The positive magnetic anomaly on the east end of the profile can be modeled by a large body beneath the surface similar to that in cross section one (density contrast 0 , susceptibility $0.035 \mathrm{SI}$, light blue line line). This body crops out and the base of the unit is shallower than in cross section one. The amplitude of the anomaly 
in cross section CS-2 is $100 \mathrm{nT}$ versus $130 \mathrm{nT}$ in cross section CS-1. Therefore the body is modeled as thinner. Several normally magnetized units can be modeled in the basement; while there effect is small (dark pink lines) they were included because they are very evident on the magnetic map (Figure 4.2,G).

Cross section CS-3 (Figure 5.7) was not constrained by a seismic line. The densities and susceptibilities used in the previous two cross sections were applied to this model in order to determine the layer geometry. The body primarily responsible for the negative gravity anomaly is the upper fill (density contrast $-500 \mathrm{~kg} / \mathrm{m}^{3}$, susceptibility $0,0.48 \mathrm{~km}$ thick, yellow line), however, it has less of a response than in the first two cross sections, primarily because it is thinner. Each lower layer is responsible for less of the anomaly (upper fill, density contrast $-320 \mathrm{~kg} / \mathrm{m}^{3}$, susceptibility $0,0.75 \mathrm{~km}$ thick, pink line; Pantano Formation density contrast -120 $\mathrm{kg} / \mathrm{m}^{3}$, susceptibility $0,0.64 \mathrm{~km}$ thick, purple line; other sedimentary rocks, density contrast $+100 \mathrm{~kg} / \mathrm{m}^{3}$, susceptibility $0,0.65 \mathrm{~km}$ thick, light green line). The preMiocene sedimentary rocks are modeled here as dense Paleozoic limestone and marble based on analysis of the gravity and magnetic maps above. A change in dip of the western edge is shown in the peak in amplitude of the gravity maximum horizontal gradient (Figure 1.14,b, dashed blue line; Figure. 3.3). This apparent steep dip on the western side of the basin is similar to the western side of cross section CS2. The eastern dip is slightly steeper than the western. The outcrop on the eastern edge of the cross section is a thin layer $(\sim 1 \mathrm{~km})$ of Precambrian granite (density contrast 200 , susceptibility 0.0035 SI) underlain by the large magnetic body modeled in the previous two cross sections (density contrast 0 , susceptibility $0.035 \mathrm{SI}$, light 
blue line). This body is responsible for almost the entire magnetic anomaly along the profile (light blue line line). Outcrop of the Ruby Star Granodiorite on the western side contributes very little to the magnetic anomaly (susceptibility 0.0035 , Figure 5.7, c, black/white line) but is responsible for the gravity high on the western edge of the basin (density contrast $+30 \mathrm{~kg} / \mathrm{m}^{3}$ ). A thin reversely magnetized volcanic layer on the western side is included in the model (density contrast $-270 \mathrm{~kg} / \mathrm{m}^{3}$, susceptibility $0.15,20 \mathrm{~m}$ thick, dark blue line).

\section{Model sensitivity}

In order to test the sensitivity of the model to the input density and susceptibility contrasts, I varied the density contrasts of the basin units and the country rock but left the depth to the top of the Pantano Formation fixed (at $1.88 \mathrm{~km}$ depth in cross section CS-1). For cross section CS-1, increasing the density contrast of the upper fill by $50 \%\left(-500 \mathrm{~kg} / \mathrm{m}^{3}\right.$ to $\left.-750 \mathrm{~kg} / \mathrm{m}^{3}\right)$ and allowing the lower fill thickness to vary, decreases the modeled upper fill thickness from $0.908 \mathrm{~km}$ to 0.46 $\mathrm{km}$, or roughly $50 \%$. The dip on the eastern side of the basin shallowed from roughly 9 degrees to 4.5 degrees. The dips on the western edge of the basin were not affected. Increasing the density contrast of the lower fill by $25 \%$, from $-320 \mathrm{~kg} / \mathrm{m}^{3}$ to $400 \mathrm{~kg} / \mathrm{m}^{3}$, holding the density of the upper fill and Pantano Formation constant, decreased the thickness of the upper fill by $50 \%$ from $0.972 \mathrm{~km}$ to $0.54 \mathrm{~km}$ and decreased the upper fill. The dips in the lower fill shallowed on the western side from 21.5 degrees to roughly 10 degrees. Some of the dips on the eastern side of the basin increased and some decreased, but most remained unchanged at 20 degrees. Increasing the lower fill density contrast by $50 \%$ from $-320 \mathrm{~kg} / \mathrm{m}^{3}$ to $-480 \mathrm{~kg} / \mathrm{m}^{3}$ and 
not moving the fixed top of the Pantano Formation, the upper fill cannot be made thin enough to fit the gravity profile alone.

The modeled upper and lower fill represent rocks deposited during and after the basin and range extension event beginning $~ 13 \mathrm{Ma}$, and lying unconformably on top of the Pantano Formation. However, the interface between the upper and lower fill is not evident in the seismic reflection data. With this in mind I decided to determine if the fill above the Pantano Formation could be modeled with just one density contrast and if this assumption would affect the location of the top of the Pantano Formation in the models. Table 4 shows the results of changing the density

\begin{tabular}{|lccc|}
\hline \multicolumn{1}{|c}{ Fill Description } & $\begin{array}{c}\text { Density } \\
\mathrm{kg} / \mathrm{m}^{3}\end{array}$ & $\begin{array}{c}\text { Density } \\
\text { Contrast } \\
\mathrm{kg} / \mathrm{m}^{3}\end{array}$ & $\begin{array}{c}\text { Depth to top } \\
\text { of Pantano } \\
\text { Formation }\end{array}$ \\
\hline one fill, inverted density & 2289 & -381 & $1.88 \mathrm{~km}$ \\
\hline one fill, lowest reasonable density & 2175 & -495 & $1.76 \mathrm{~km}$ \\
\hline one fill, highest reasonable density & 2335 & -335 & $2.52 \mathrm{~km}$ \\
\hline one fill, Top of Pantano at Eberly \& Stanley depth & 2308 & -362 & $2.19 \mathrm{~km}$ \\
\hline one fill, weighted average density & 2252 & -418 & \\
\hline
\end{tabular}

Table 4: The results of changing the density contrast and the depth to the top of the Pantano Formation.

contrast and the depth to the top of the Pantano Formation. Modeling with the highest $\left(-495 \mathrm{~kg} / \mathrm{m}^{3}\right)$ and lowest $\left(-335 \mathrm{~kg} / \mathrm{m}^{3}\right)$ geologically feasible density contrasts (a weighted average of the highest or lowest densities recorded in the Exxon well (32) density logs) results in a single basin fill thickness of $1.76 \mathrm{~km}$ and $2.52 \mathrm{~km}$ respectively on cross section CS-1. The $2.52 \mathrm{~km}$ depth calculated with the lowest density contrast resulted in a zero thickness of the Pantano Formation in the deepest portion of the model, violating the constraints. Inverting for density contrast while 
holding the top of the Pantano Formation fixed to a depth of $1.88 \mathrm{~km}$ (the depth recorded in the Exxon well (32)) resulted in a density contrast of $-381 \mathrm{~kg} / \mathrm{m}^{3}$. This value is less than the weighted average density contrast of $-418 \mathrm{~kg} / \mathrm{m}^{3}$ from the Exxon well (32) density log. To try to ascertain whether the depth at which Eberly and Stanley (1978) placed the bottom of the basin fill (at the top of the lava flow in the Exxon well (32)) is a better estimate than that obtained from Houser and Gettings (2000), I fixed the bottom of the basin fill at $2.194 \mathrm{~km}$ depth. The resulting density contrast is $-362 \mathrm{~kg} / \mathrm{m}^{3}$, lower than would be expected from the weighted average density contrast of the well log, suggesting that the shallower depth determined by Houser and Gettings (2000) is more accurate.

Changing the susceptibilities of the main inferred Laramide diorite body on the eastern sides of the models shows that the upper interface is not very sensitive to a change in susceptibility (i.e., the interface stays the same). Decreasing the susceptibility from 0.035 (SI) to 0.03 (SI) can be accommodated in the model, by increasing the thickness of the body down to the Curie depth of $12 \mathrm{~km}$ (Hong, Aiken, and others, 1982). Decreasing the susceptibility further to 0.025 (SI), the magnetic body's upper interface cannot be made shallow enough to fit the magnetic profile. Increasing the susceptibility results in a thinner magnetic body. Without changing the magnetic/non-magnetic interface I can raise the susceptibility to 0.08 (SI), which is an unreasonable value for a pluton.

Areal Extent of the Basin:

Combining the results of the modeling, maximum horizontal gradients of the gravity and pseudogravity and the map view of the gravity anomaly allows 
delineation of the 3-dimensional extent of the basin. The results of the modeling of the three cross sections can be gridded (linear interpolation using MATLAB) to create contour maps of the depths to the bottom of the upper (Figure, 5.8, a) and lower fill (Figure 5.8, b) and the bottom of the Pantano Formation (Figure 5.8, c). These contour maps depict the variations in the lateral and vertical extents of the lower fill and the Pantano Formation. For both lithologic units, the depths to the bottom of the units shallow and narrow to the south. The lower fill unit has roughly the same lateral extent in the south as the Pantano Formation, but the lower fill deepens towards the north and central portion of the basin. The depth to the bottom of the Pantano Formation however seems deepest between cross section two and at the eastern edge of cross section one.

\section{Three-dimensional character of the basin}

These results suggest that the deepest portion of the basin is towards the northern end, however, the Bouguer gravity anomaly values (Figure 4.1) decrease towards the north suggesting the basin shallows. Therefore, further correction of the gravity data is needed to isolate the gravity anomaly associated with the basin fill. Removing the gravity effect of changes in crustal thickness and variations in the density of the bedrock (Saltus and Jachens, 1995) produces a residual basin gravity anomaly with lowest values over the area identified as the deepest part of the basin by my modeling. Therefore, I decided to use their residual basin gravity anomaly to help extend the $2 \frac{1}{2}$ dimensional modeling to three-dimensions. The regional gravity corrections were made to isolate the gravity anomaly associated with the postOligocene sedimentary units. 

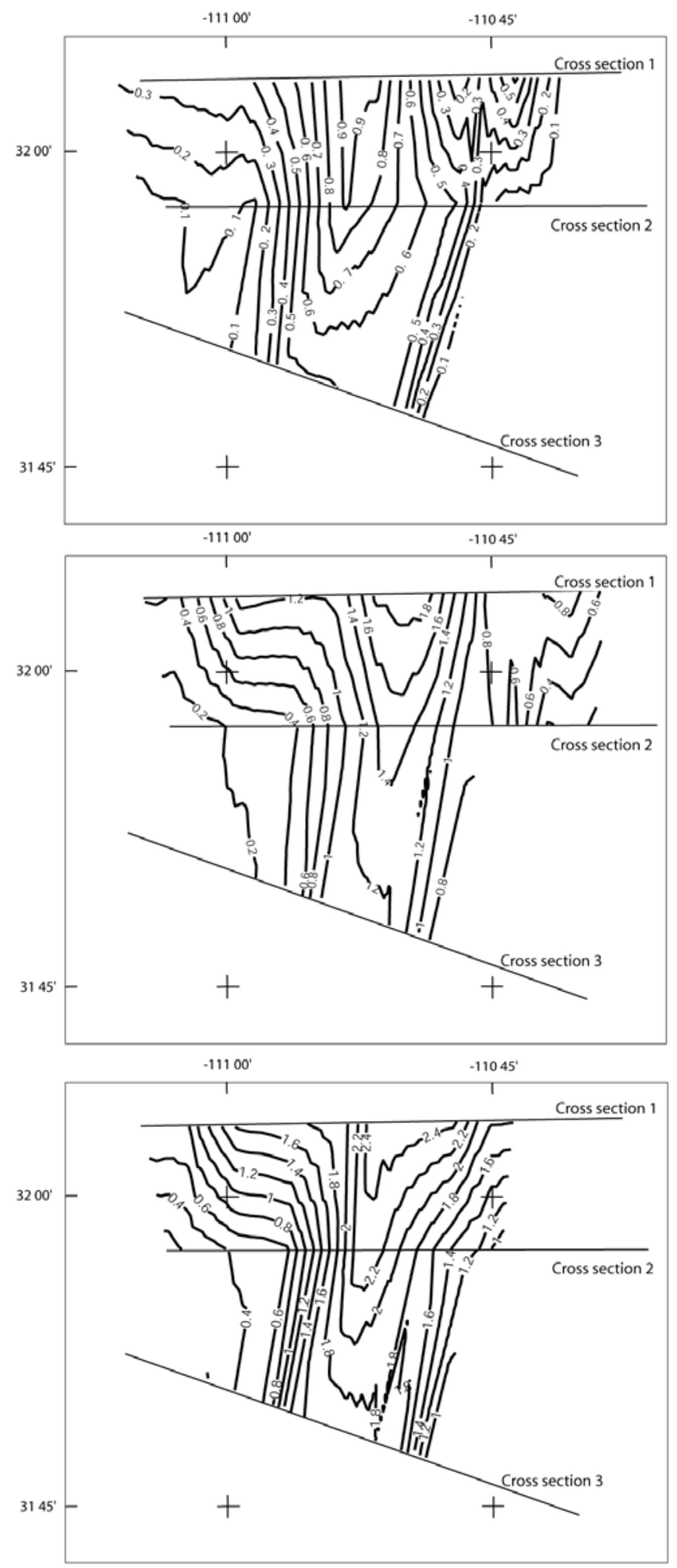

A. Depth to bottom of upper fill

B. Depth to bottom of lower fill
C. Depth to bottom of Pantano Formation

Figure 5.8: Depth to bottom of units contoured from model profiles (figures 5.5-5.7). Model cross sections shown. Linear interpolation. Contours are $0.2 \mathrm{~km}$. 


\section{Gravity Corrections}

The Bouguer reduction process removes the gravitational attraction of topographic masses down to sea level, but the compensating mass underneath the topographic highs is not accounted for and can produce Bouguer gravity anomaly lows (Simpson, Jachens, and others, 1986). Therefore in order to remove the attraction of compensating masses an isostatic reduction was applied. This regional field is the gravitational effect of topographic roots calculated using the AiryHeiskanen model with a density contrast across the root of $350 \mathrm{~kg} / \mathrm{m} 3$, topographic load density of $2670 \mathrm{~kg} / \mathrm{m} 3$, depth to root at sea level of $30 \mathrm{~km}$ and topographical data (Simpson, Jachens, and others, 1986) (Figure 5.9). The removal of the isostatic anomaly results in the residual isostatic gravity anomaly map (Figure 5.10).

The residual isostatic gravity anomaly map still indicates that the deepest portion of the basin is just south of cross section CS-2, suggesting that the basement rocks in the northern end of the basin have a higher density than the rocks to the south. This would result in a higher density contrast with the basin fill and an underestimation of the thickness of the fill in the northern portion of the basin. Therefore, the basin gravity anomaly still needs to be separated from the basement signature. The basement gravity map, from Saltus and Jachens (1995), was produced by gridding only the gravity stations that are on basement outcrop (Figure 5.11). The map shows that higher density rocks are in the north, and lower density rocks are in the south, in accord with geologic map (Figure 1.1), that shows dense, plutonic rocks in the north and lower density volcaniclastic and sedimentary rocks to the south. This 


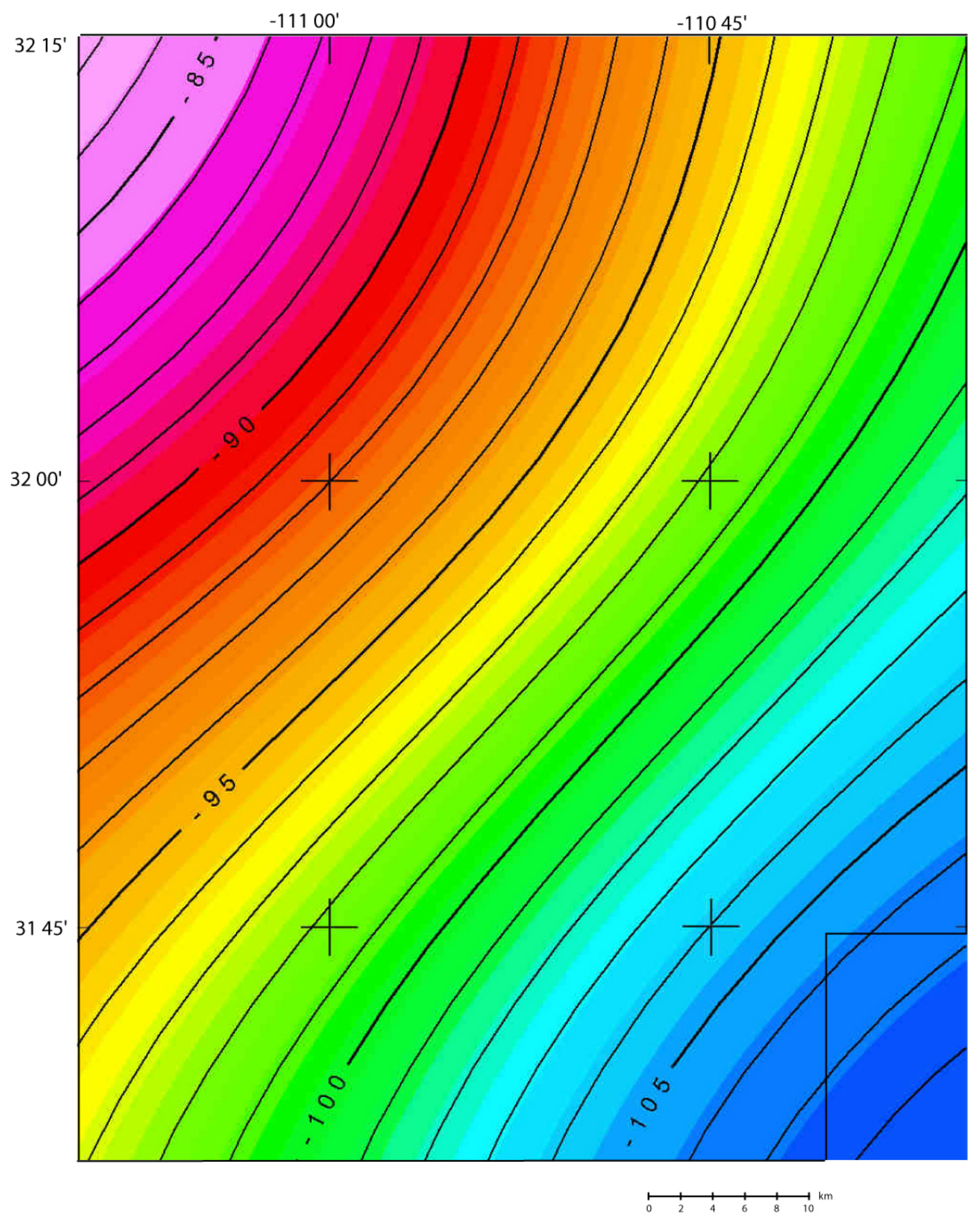

Figure 5.9: Regional isostatic gravity field, $1 \mathrm{mGal}$ contours (discussed more in text). From Saltus and Jachens (1995). 


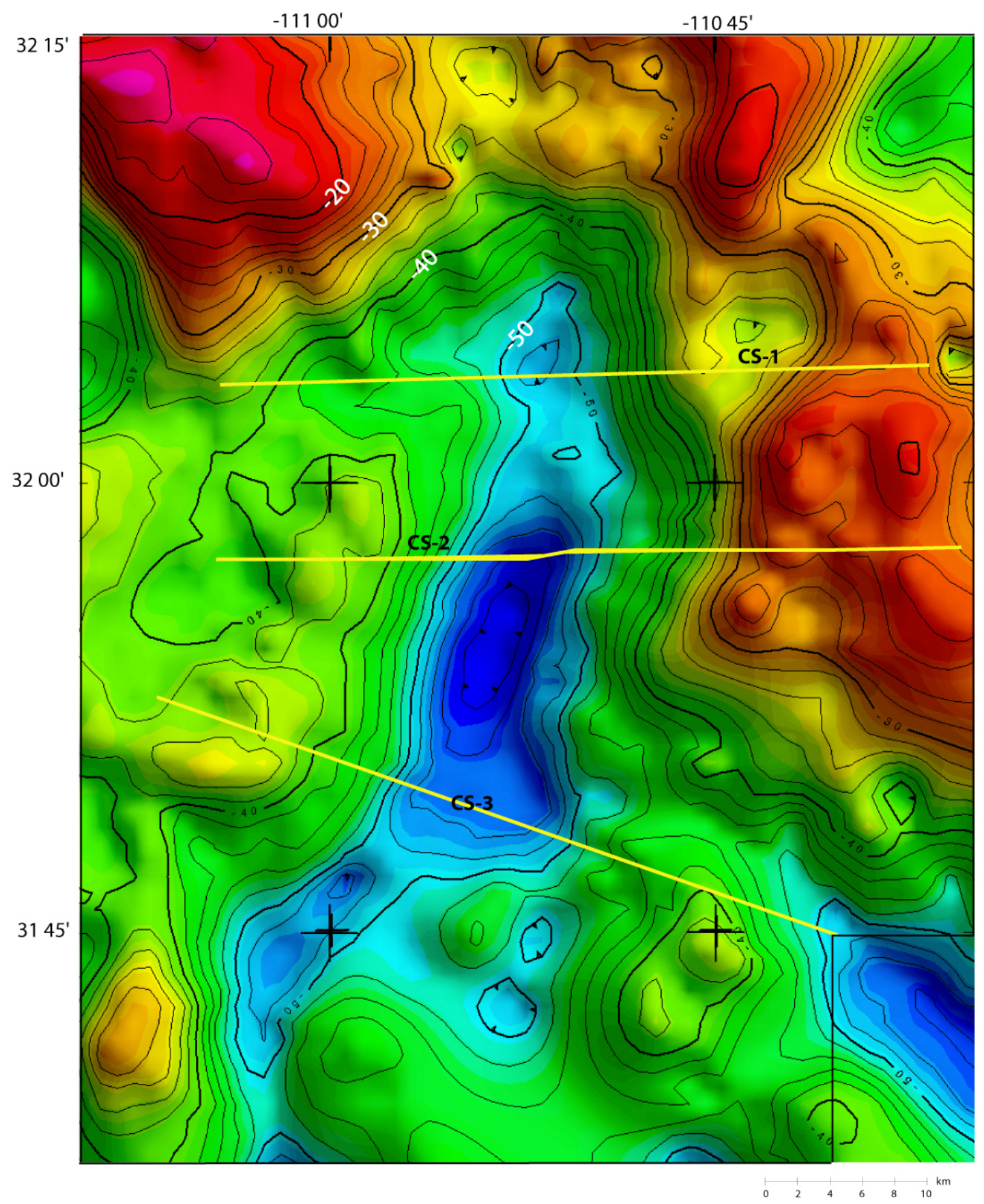

Figure 5.10: Residual isostatic gravity anomaly map. Bouguer gravity (Figure 3.2) with isostatic compensation (Figure 5.9) removed. $2 \mathrm{mGal}$ contour interval. 


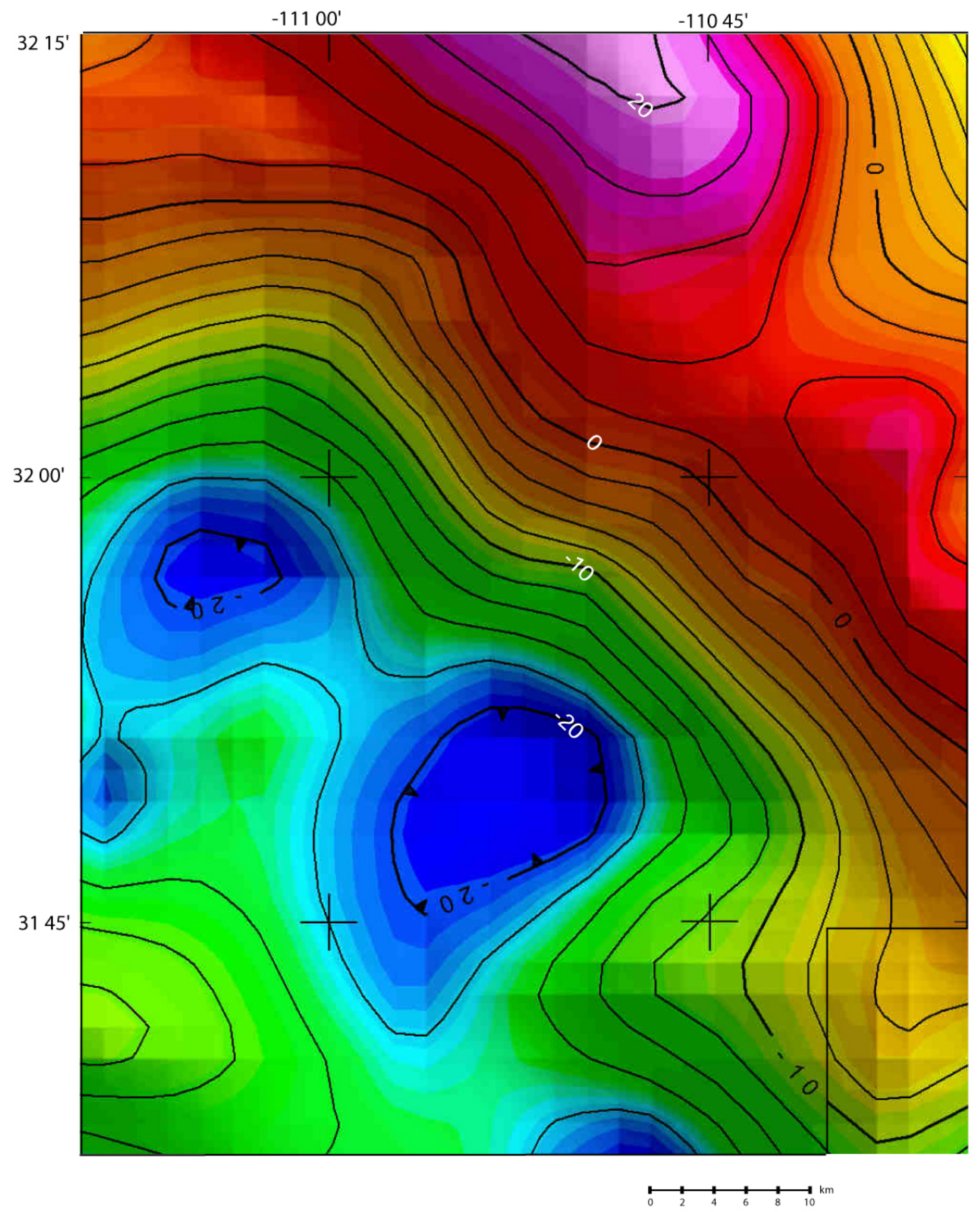

Figure 5.11: Basement gravity map from Saltus and Jachens [1995]. Lateral density variations in the basement are delineated. Contour interval is $2 \mathrm{mGals}$. 


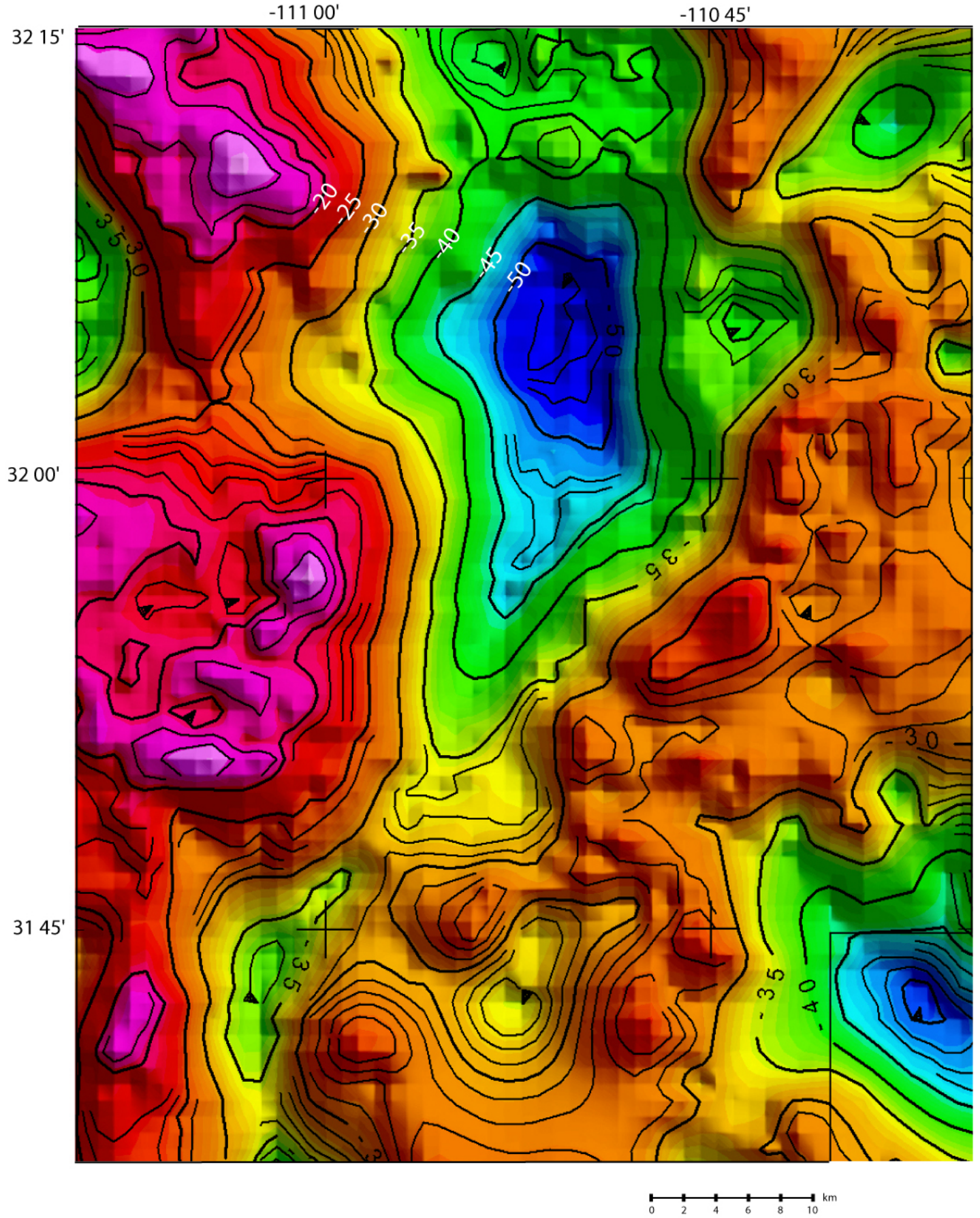

Figure 5.12: Basin residual gravity map, Residual isostatic gravity anomaly map (Figure 5.10) with basement gravity removed (Figure 5.11). The contour interval is 5 mGals. 
basement gravity anomaly was removed from the isostatic residual gravity anomaly to produce the basin residual gravity map (Figure 5.12). This map shows the extent of the gravity anomaly due primarily to the density contrast of the upper and lower basin fill with the surrounding country rock. Now the lowest gravity anomalies lie over the northern portion of the basin and agree with the depth contour maps for the southern half (figure 5.13).

The peak amplitudes of the maximum horizontal gradient of the gravity (Figure 3.3) and pseudogravity (Figure 3.7) that delineate the edges of the basins in the cross sections (dashed blue lines, Figure 5.5-5.7, a and b) are overlain on the residual basin gravity anomaly map (Figure 5.14) to show the locations of density or magnetic boundaries. The edges of the basin, where low-density fill juxtaposes higher density basement, if steep, should appear as a maximum horizontal gradient in the gravity. Where steep magnetic boundaries exist, the pseudogravity maximum horizontal gradient will delineate the edge. Since the gravity anomalies represent the density contrast of the basin fill, and the magnetic anomalies represent the igneous and volcanic rocks on the basin edges and beneath the fill, it is logical that the maximum horizontal gradients of the gravity would better represent the edges of the basin. Where the gradients coincide the fill juxtaposes a high density, high susceptibility rock.

South of profile CS-2, the western edge of the sedimentary basin is delineated by a gravity maximum horizontal gradient (Figure 5.14, A, blue line; Figures. 5.5-5.7 b). This trend shows that the edge of the basin is a steep contact, for moderate to shallow dipping contacts of rock of differing densities or susceptibility are not picked 


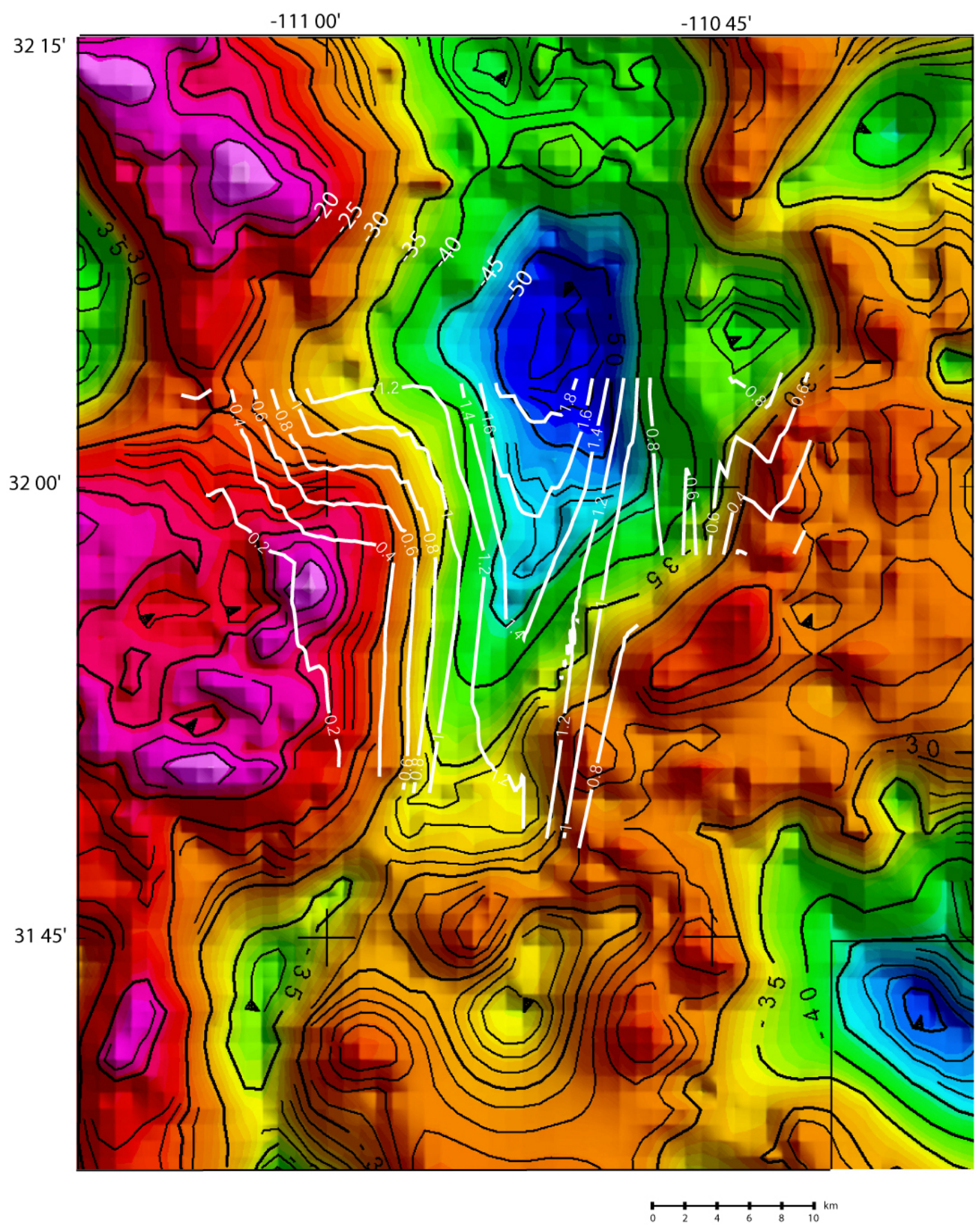

Figure 5.13: Basin residual gravity map (Figure 5.12) with contours denoting depth to bottom of lower fill (white lines) (from Figure 5.8). Gravity contour interval (black) is $5 \mathrm{mGal}$. 


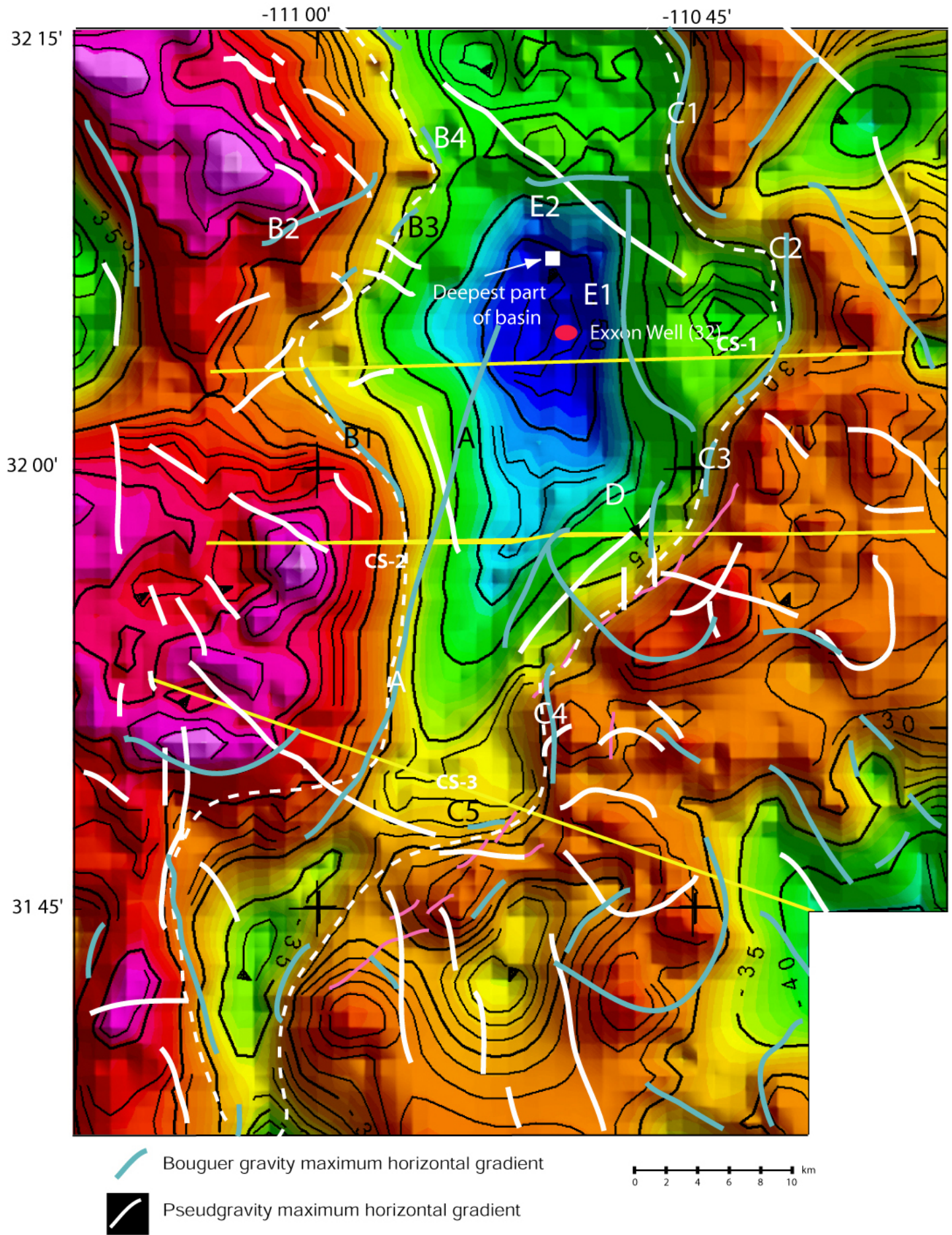

Figure 5.14: Gravity and pseudogravity maximum horizontal gradient line overlain on the basin residual gravity map with a contour interval of $5 \mathrm{mGals}$ (Figure 5.12). Letters are referred to in the text. White square is estimated deepest portion of the basin, white dashed lines are estimated basin extent. Yellow lines locations of modeled cross sections. 
up well in the maximum horizontal gradient method (Blakely, 1995). This finding agrees with the modeling of the cross sections (Figures, 5.5-5.7b). Further to the north (Figure 5.14, B1, B3, B4, blue lines) additional gravity maximum horizontal gradients delineate the edges of the basin.

Several clear maximum horizontal gradient gravity trends define the eastern edge of the basin (Figure 5.14, C1-C5, blue lines). C2 is apparent on cross section CS-1 (Figure 5.5, b, km 35). Both gravity and pseudogravity maximum horizontal gradients coincide (Figure 5.14, D, white and blue lines) and correlate with the steep edge of the basin modeled in cross section CS-2 ( $\mathrm{km} \mathrm{30,} \mathrm{Figure} \mathrm{5.6,} \mathrm{c).} \mathrm{This} \mathrm{steep}$ edge is associated with the location of the Santa Rita fault determined from seismic refraction (Rutledge, 1984) and reflection (Johnson and Loy, 1992) data. Two horizontal gravity gradient trends (Figure 5.14, E1, E2, blue lines) lie within the basin. These gradients probably delineate a subbasin, representing edges of the deeper and older portions of the basin.

Combining the modeling results with the gradient analysis above allows me to characterize the 3-dimensional geometry of the basin. Using the gradients to delineate the edges of the basin (Figure 5.14, dotted white line) shows that the width of the upper portion of the basin decreases from about $27 \mathrm{~km}$ in the north to $10 \mathrm{~km}$ in the south. The length of the basin is $\sim 63 \mathrm{~km}$. The basin (that is, the depth to the bottom of the Pantano Formation) shallows from $2.5 \mathrm{~km}$ just north of the Exxon well (32) (Figure 5.14, white box) to $1.88 \mathrm{~km}$ at the southern-most end. 
Areal Extent of the Igneous Basement:

Modeling and correlation of anomalies with outcrop and drillhole data has shown that the magnetic anomalies can be used to determine the basement geology for the east side of the study area and the distribution of volcanic rocks on the west side (Figure 5.15). Much of the discussion on the rationale for delineating the various units is described in the anomaly identification section. From the modeling and correlation with outcrop, we determine that the large positive anomaly in the northern portion of the basin (Figure 4.2, A5) is related to the Laramide-age diorite/granodiorite plutons that underlie the Rincon and Santa Rita Mountains. While several outcrops of Precambrian granodiorite correlate with these magnetic highs, measurements show them to be approximately non-magnetic and modeling shows thin bodies. The basement geologic map shows that the much of the Tucson Basin is underlain by Laramide-age diorite/granodiorite intrusions and that the basement high that bounds the basin on the south is composed of these diorites/granodiorites. The southern portion of the basin (just north of cross section CS-3) is underlain by nonmagnetic rocks. The amplitude and wavelength of the anomalies over this portion of the basin are similar to Paleozoic sedimentary sequences that crop out to the southeast, suggesting a similar source. To the west, the magnetic signature of the shallow, reversely and normally magnetized mid-Tertiary volcanic rocks (Figure 5.15) obscure the magnetic signature of the basement. From cross section modeling, I show that the western basement is non-magnetic, and may correspond in the south to the Paleozoic sedimentary sequences inferred to underlie the basin. The lower half of 
the central-west portions of the Tucson Basin appear to have been intruded by

Tertiary andesite and diorite dikes (Figure 5.15). 


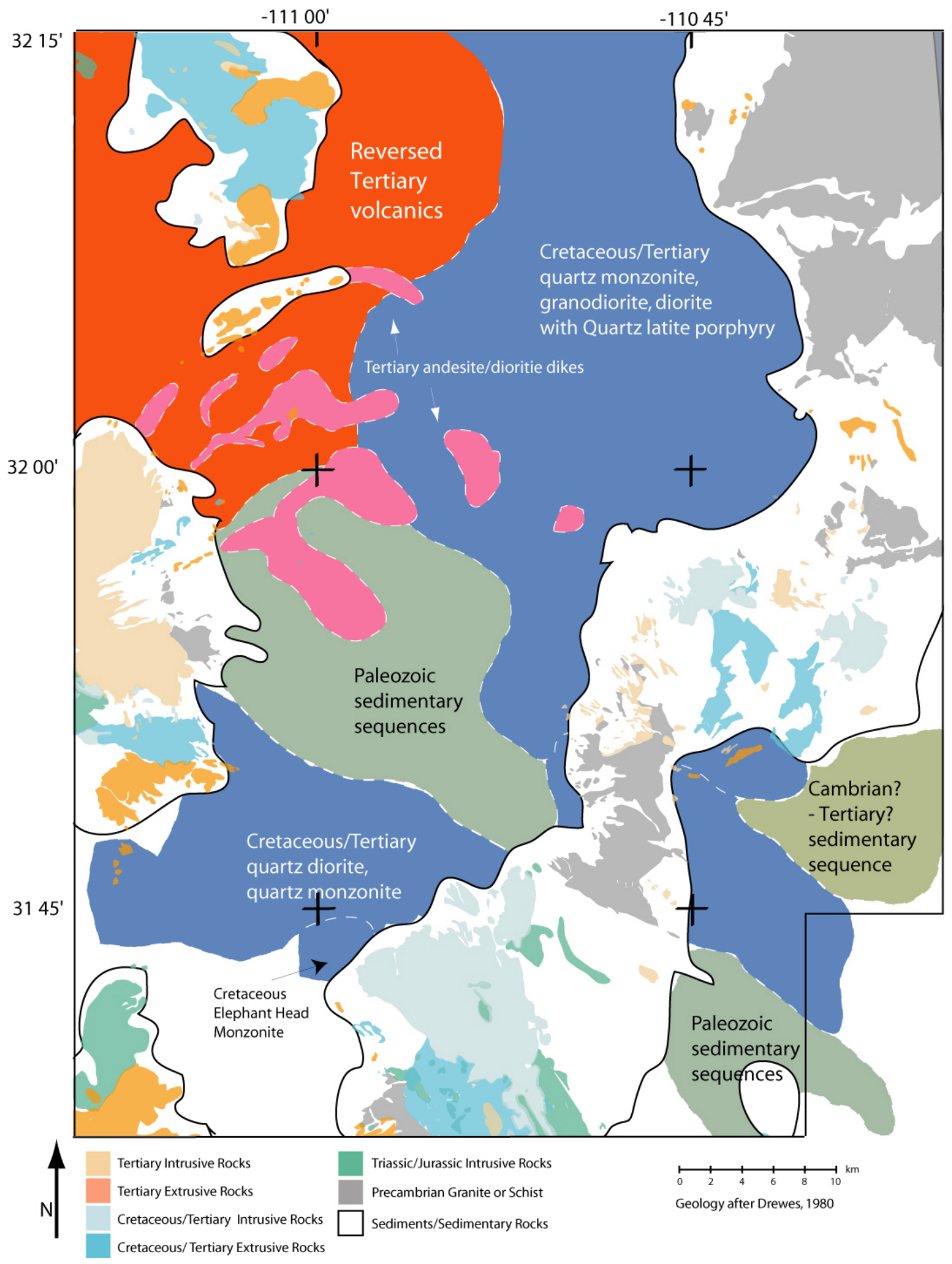

Figure 5.15: Sources of magnetic anomalies as determined from reduced-to-the-pole aeromagnetic data. Generalized geology from figure 1.1 without Quaternary sediments and Pantano Formation. Black outlines delimit edges of sedimentary rocks. 


\section{Chapter 6}

\section{DISCUSSION:}

This 3-dimensional view of the Tucson Basin was determined by using many geologic and geophysical data sets. This relatively well constrained result can be compared to the several other modeling approaches used on the Tucson Basin. Several key points differentiate my model from previous ones. From a gravity modeling standpoint, I assume that the bottom of the basin is at the bottom of the Pantano Formation, below which the density contrast is zero. Geologically, the bottom of the basin is the top of the Pantano (the Pantano crops out on either side of the basin). The Pantano contributes little to the gravity signature (Figs. 5.5-5.7); our modeling reflects this. I constrained the densities used in the model from well logs and surface density measurements instead of assuming a density function.

Davis (1971) used residual Bouguer gravity to model the depth to basement defined as pre-Tertiary basement rocks; therefore his depth estimates mark the bottom of the Pantano Formation. His depth to basement approximates the shape of the Bouguer gravity anomaly, with the deepest portion of the basement in the south at a depth of $2150 \mathrm{~m}$. The density contrast of $-400 \mathrm{~kg} / \mathrm{m}^{3}$ is a fair estimate for the fill above the Pantano Formation, but is a bit high when including the Pantano Formation. Also, failure to remove the basement gravity anomalies resulted in determining that the northern portion of the basin was much shallower than the Exxon well (32) records (1.5 km vs. $2.5 \mathrm{~km}$ depth to the bottom of the Pantano Formation, Figure 5.1).

Litinsky (1989) modeled the same data set as Davis (1971) with a different density/depth model, that had an effective density contrast of $-137 \mathrm{~kg} / \mathrm{m}^{3}$ and yielded 
a maximum depth of $10 \mathrm{~km}$ in the southern portion of the basin. His formula for determining the effective density contrast used the gravity anomaly and depth to bedrock over the Exxon well (32). The bulk density log from the Exxon well (32) (Houser and Gettings, 2000), shows the density contrast below the bottom of the Pantano Formation is zero, however Litinsky calculated an effective density contrast based on a basin depth of $3.66 \mathrm{~km}$. Since the thickness of the basin is really $\sim 2.5 \mathrm{~km}$ at the location of Exxon well (32), the effective density contrast calculated by Litinsky is underestimated, ranging from $281-244 \mathrm{~kg} / \mathrm{m}^{3}$. In comparison, inverting for one fill I calculate the density contrast for cross section CS-1 to be $\sim-300 \mathrm{~kg} / \mathrm{m}^{3}$. An underestimate of the density contrast, coupled with the failure to remove the basement gravity anomalies led Litinsky to estimate a depth of $10 \mathrm{~km}$ in the southern portion of the basin compared to my estimates of $1.93 \mathrm{~km}$. Ignoring the bulk density information on the layered units in the Tucson Basin in this case has lead to excessive depth estimates based on the erroneous assumption that the bottom of the basin is at the top of the granitoid rather than near the bottom of the Pantano Formation

Chakravarthi, et al., (2001) modeled a residual Bouguer gravity profile similar to my cross section CS-1. Using a surface density contrast of $-450 \mathrm{~kg} / \mathrm{m}^{3}$ and a parabolic density function, they created a depth section. This profile has the approximate shape of my modeled cross section CS-1, but contains no geologic or dip information and has exaggerated depth estimates. The authors do not state whether this is the surface of the igneous basement or bottom of the Pantano Formation. Therefore, any conclusions about the tectonic history are left unanswered. 
Saltus and Jachens (1995) modeled the residual basin gravity over the western US and calculated maximum depths to Pre-Cenozoic basement to be $\sim 2 \mathrm{~km}$. This estimate is too shallow because of their assumption that the density contrast is a constant $-250 \mathrm{~kg} / \mathrm{m}^{3}$ below $1.2 \mathrm{~km}$ (too high for the lower portion of the basin). This causes an overestimate of the total density contrast and therefore, underestimates the basin thickness. Like our model, they show the Tucson Basin shallowing to the south, however, their model shallows to $1 \mathrm{~km}$ in the location of my cross section CS2, versus $2.2 \mathrm{~km}$ in my model and $0.5 \mathrm{~km}$ along cross section CS-3, versus $1.8 \mathrm{~km}$ in my model. Their depth density contrasts were an average of the entire western US and not taken from local density measurements.

Using all available data sets results in a much more accurate model of the Tucson Basin. Identifying what defines the basement, using density contrasts from well logs, gives a much better model of the basin. 


\section{Chapter 7}

\section{CONCLUSIONS:}

By modeling of gravity and magnetic data, I show the 3-D extent of the Tucson Basin. The cross sections and the contour maps generated from them show the lateral extent and thickness of basin fill; the magnetic and gravity maps show the character of the basin away from the cross-sections. These two pieces of information together generate a 3-D picture of the Tucson Basin. The gravity effects of the upper and lower basin fill produce most of the Bouguer gravity low over the basin. As these rocks relate to the most recent extensional event in the region (Basin and Range extension) my model will help determine the amount of extension required to form the basin. The seismic reflection and well data show that the upper basin fill is unfaulted while the lower portion is faulted, suggesting a different tectonic history. The lower fill was deposited during active extension while the upper fill represents deposition due to changes in location of rivers as well as erosion (e.g. Houser and Gettings, 2000).

Modeling also shows that the magnetic anomalies primarily emanate from the basement, that is below the sedimentary layers that comprise the basin, except in the northwest where Tertiary volcanics lie close to the surface. The large amplitude, moderate wavelength magnetic anomalies are related to Laramide-age diorites and granodiorites that dip west under the basin. A few Early Tertiary andesite or diorite intrusions penetrate the sedimentary basin. Reversely magnetized Early Tertiary volcanics are shallowly buried along the western edge of the basin, and Paleozoic? 
sedimentary rocks are thought to lie beneath the basin just north of the Sawmill Canyon Fault, connecting with similar rocks to the southeast. 


\section{REFERENCES:}

Anderson, S.R., Cenozoic stratigraphy and geologic history of the Tucson Basin, Pima County, Arizona, pp. 20, U. S. Geological Survey, Reston, 1987.

Anderson, T.W., Electrical-Anaolog analysis of the hydrologic system, Tucson Basin, southeastern Arizona, U.S. Geological Survey, Reston, 1972.

Andreasen, G.E., and J.A. Pitkin, Aeromagnetic map of the Twin Buttes area, Pima and Santa Cruz counties, Arizona, U. S. Geological Survey, Reston, 1963.

Asmerom, Y., R.E. Zartman, P.E. Damon, M. Shafiqullah, and Anonymous, U-Th-Pb zircon ages from Santa Rita Mtns., SE Arizona; implications for timing of early Mesozoic magmatism, in Geological Society of America, Cordilleran Section, 84th annual meeting, pp. 140, Geological Society of America (GSA), Boulder, 1988.

Baldyga, C.A., Relationship of faults in basin sediments to the gravity and magnetic expression of their underlying fault systems, U.S. Geological Survey OpenFile Report, 01-502, 2001.

Baranov, V., and H. Naudy, Numerical calculation of the formula of reduction to the magnetic pole, Geophysics, 29, 67-79, 1964.

Blakely, R.J., Potential Theory in Gravity and Magnetic Applications, 441 pp., Cambridge University Press, Cambridge, 1995.

Burkham, D.E., Depletion of streamflow by infiltration in the main channels of the Tucson Basin, southeastern Arizona, U. S. Geological Survey, Reston, 1970.

Butler, W.C., Permian sedimentary environments in southeastern Arizona, Arizona Geological Society Digest, 9, 71-94, 1971.

Chakravarthi, V., S.B. SIngh, and G. Ashok Babu, INVER2DBASE--A program to compute basement depths of density interfaces above which the density contrast varies with depth, Computers \& Geosciences, 27, 1127-1133, 2001.

Coney, P.J., Tertiary evolution of Cordilleran metamorphic core complexes, in Cenozoic paleogeography of the western United States, edited by J.M.

Armentrout, M.R. Cole, and H. TerBest, Jr., pp. 14-28, Pacific Section, Society of Economic Paleontologists and Mineralogists, 1979.

Cooley, M.E., Map showing distribution and estimated thickness of alluvial deposits in the Tucson area, Arizona, U. S. Geological Survey, Reston, 1973.

Cordell, L., and V.J.S. Grauch, Mapping basement magnetization zones from aeromagnetic data in the SanJuan basin, New Mexico, in The utility of regional gravity and aeromagnetic map, edited by W.J. Hinze, pp. 181-197, Society of Exploration Geophysicists, 1985.

Davidson, E.S., Geohydrology and water resources of the Tucson Basin, Arizona, U. S. Geological Survey, Reston, 1973.

Davis, G.H., Regional strain analysis of the superposed deformations in southeastern Arizona and the eastern Great Basin, in Relations of tectonics to ore deposits in the southern Cordillera, edited by W.R. Dickinson, and W.D. Payne, pp. 155-172, Arizona Geological Society, Tucson, 1981. 
Davis, R.W., A geophysical investigation of hydrologic boundaries in the Tucson Basin, Pima County, Arizona, Doctoral thesis, University of Arizona, Tucson, 1967.

Davis, R.W., An analysis of gravity data from the Tucson Basin, Arizona, Arizona Geological Society Digest, 9, 103-121, 1971.

de la Torre, A.C., Streamflow in the upper Santa Cruz River basin, Santa Cruz and Pima counties, Arizona, U. S. Geological Survey, Reston, 1970.

Dickinson, W.R., Tectonic setting of Arizona through geologic time, Arizona Geological Society Digest, 17, 1-16, 1989.

Drewes, H., Plutonic rocks of the Santa Rita Mountains, southeast of Tucson, Arizona, pp. 75, U. S. Geological Survey, Reston, 1976.

Drewes, H., Tectonic map of Southeast Arizona, pp. 2, U. S. Geological Survey, Reston, 1980.

Drewes, H.D., Geologic map of the Mount Wrightson Quadrangle, southeast of Tucson, Santa Cruz, and Pima counties, Arizona, U. S. Geological Survey, Reston, 1971.

Drewes, H.D., Tectonics of Southeastern Arizona, 96 pp., U.S. Geological Survey, Washington, 1981.

Eberly, L.D., and T.B. Stanley Jr., Cenozoic stratigraphy and geologic history of southwestern Arizona, Geological Society of America Bulletin, 89, 921-940, 1978.

Gettings, M., An interpretation of the 1996 aeromagnetic data for the Santa Cruz basin, Tumacacori Mountains, Santa Rita Mountains, and Patagonia Mountains area, south-central Arizona, US Geological Survey Open-File Report, 02-0099, 2002.

Gettings, M.E., and B.B. Houser, Basin Geology of the Upper Santa Cruz Valley, Pima and Santa Cruz Counties, Southeastern Arizona, US Geological Survey Open-File Report, 97-676, 1997.

Grauch, V.J.S., D.A. Sawyer, C.J. Fridrich, and M.R. Hudson, Geophysical interpretations west of and within the northwestern part of the Nevada Test Site, pp. 51, U. S. Geological Survey, Reston, 1997.

Hong, M.R., C.L.V. Aiken, W.J. Peeples, and Anonymous, Depth to Curie isotherm in Arizona by magnetic anomaly inversion, in SEG Abstracts, pp. 491-493, Society of Exploration Geophysicists, International Meeting and Exposition, 1982.

Houser, B.B., and M.E. Gettings, Stratigraphy and tectonic history of the Tucson basin, Arizona, based on re-examination of cuttings and geophysical logs of Exxon State (32)-1 well, in Open-File Report 00-139, pp. 38, 2000.

Howard, K.A., Intrusion of horizontal dikes; tectonic significance of middle Proterozoic diabase sheets widespread in the upper crust of the Southwestern United States, in Special section on CACTIS III [modified], pp. 12,46112,478, American Geophysical Union, Washington, 1991.

Johnson, R.A., and K.L. Loy, Seismic reflection evidence for seismogenic low-angle faulting in southeastern Arizona, Geology (Boulder), 20 (7), 597-600, 1992. 
Karlstrom, K.E., and E.D. Humphreys, Persistent influence of Proterozoic accretionary boundaries in the tectonic evolution of southwestern North America; interaction of cratonic grain and mantle modification events, Rocky Mountain Geology, 33 (2), 161-179, 1998.

Keep, M., The Pinal Schist, Southeast Arizona, USA; contraction of a Palaeoproterozoic rift basin, Journal of the Geological Society of London, 153 (6), 979-993, 1996.

Laney, R.L., Chemical quality of the water in the Tucson Basin, Arizona, U. S. Geological Survey, Reston, 1972.

Litinsky, V.A., Concept of effective density: Key to gravity depth determinations for sedimentary basins, Geophysics, 54 (11), 1474-1482, 1989.

Loring, A.K., The age of basin-range faulting in Arizona [Monograph] Tectonic digest, Arizona Geological Society Digest, 10, 229-257, 1976.

Menges, C.M., and P.A. Pearthree, Late Cenozoic tectonism in Arizona and its impact on regional landscape evolution Geologic evolution of Arizona, Arizona Geological Society Digest, 17, 649-680, 1989.

Myers, S.C., and S.L. Beck, Evidence for a local crustal root beneath the Santa Catalina metamorphic core complex, Arizona, Geology, 22, 223-226, 1994.

Pashley, E.F., Jr., Structure and stratigraphy of the central, northern, and eastern parts of the Tucson Basin, Arizona, Doctoral thesis, University of Arizona, Tucson, 1966.

Pearthree, P.A., and S.S. Calvo, The Santa Rita fault zone; evidence for large magnitude earthquakes with very long recurrence intervals, Basin and Range Province of southeastern Arizona, Bulletin of the Seismological Society of America, 77 (1), 97-116, 1987.

Percious, J.K., Geology and geochronology of the Del Bac Hills, Pima County, Arizona, in Southern Arizona Guidebook 3, Geol. Soc. America Cordilleran Sec., 64th Ann. Mtg, Tucson, 1968.

Reid, A.B., Aeromagnetic survey design, Geophysics, 45, 973-976, 1980.

Reynolds, R.L., J.G. Rosenbaum, M.R. Hudson, and N.S. Fishman, Rock Magnetism, The Distribution of Magnetic Minerals in the Earth's Crust, and Aeromagnetic Anomalies, in Geologic applications of modern aeromagnetic surveys : proceedings of the U.S. Geological Survey Workshop on Geologic Applications of Modern Aeromagnetic Surveys, held January 6-8, 1987, in Lakewood, Colorado, edited by W.F. Hanna, 1990.

Rutledge, J.T., A shallow seismic refraction survey over a late quaternary fault scarp west of the Santa Rita Mountains, Arizona, M.S. thesis, University of Arizona, Tucson, 1984.

Saltus, R.W., and R.C. Jachens, Gravity and Basin-Depth Maps of the Basin and Range Province, Western United States, U.S. Geological Survey, 1995.

Sauck, W.A., J.S. Sumner, and J.P. Christensen, Aeromagnetic map of the northern part of the Tucson Basin, Pima County, Arizona, Arizona Geological Society Digest, 9, 123-135, 1971. 
Simpson, R.W., R.C. Jachens, R.J. Blakely, and R.W. Saltus, A new isostatic residual gravity map of the conterminous United States with a discussion on the significance of isostatic residual anomalies, JGR. Journal of Geophysical Research. B, 91 (8), 8348-8372, 1986.

Spencer, J.E., and S.J. Reynolds, Middle Tertiary tectonics of Arizona and adjacent areas, Arizona Geological Society Digest, 17, 539-574, 1989.

Stewart, J.H., Late Precambrian evolution of North America; plate tectonics implication, Geology, 4 (1), 11-15, 1976.

Summer, J.S., and W.A. Sauck, Arizona aeromagnetic survey, in AIME Pacific Southwest Mineral Industry Conference, Program and Abstracts, [p. 21], Am. Inst. Min., Metall. Pet. Eng., 1971.

Sweeney, R.E., and P.L. Hill, Arizona Aeromagnetic and Gravity Maps and Data: A Web Site for Distribution of Data, USGS, 2001.

Telford, W.M., L.P. Geldart, R.E. Sheriff, and D.A. Keys, Applied geophysics, Cambridge University Press, Cambridge, 1976.

Titley, S.R., Evidence for a Mesozoic linear tectonic pattern in southeastern Arizona, Arizona Geological Society Digest, 10, 71-101, 1976.

Titley, S.R., Tectonic History and Ore Genesis in the Pima Mining District, in Advances in Geology of the Porphyry Copper Deposits, edited by S.R. Titley, pp. 387-406, The University of Arizona Press, Tucson, 1982.

Tosdal, R.M., G.B. Haxel, and J.E. Wright, Jurassic Geology of the Sonoran Desert Region, Southern Arizona, Southeastern California, and Northernmost Sonora: Construction of a Continental-Margin Magmatic Arc, in Geologic Evolution of Arizona, edited by J.P. Jenney, and S.J. Reynolds, pp. 397-434, Arizona Geological Society Digest, Tucson, 1989.

Walker, S.D., Mesozoic tecotonic evolution of the Twin Buttes Mine area, Pima County, Arizona: Implications for a regional tectonic control of ore deposits in the Pima Mining District, Master's thesis, University of Arizona, Tucson, Az, 1982.

Zoback, M.D., and M.L. Zoback, Tectonic stress field of North America and relative plate motions, in Neotectonics of North America, edited by D.B. Slemmons, E.R. Engdahl, M.D. Zoback, and D.D. Blackwell, pp. 339-366, Geol. Soc. Am., Boulder, 1991. 